Denis Jacob Machado

\title{
Acanthobothrium Blanchard, 1848: \\ diversidade filogenética das linhagens parasitas de arraias de água doce
}



Denis Jacob Machado

\section{Acanthobothrium Blanchard, 1848: diversidade filogenética das linhagens parasitas de arraias de água doce}

\section{Acanthobothrium Blanchard, 1848: phylogenetic diversity of the linages that parasitize freshwater stingrays}

Dissertação apresentada ao Instituto de Biociências da Universidade de São Paulo, para a obtenção de Título de Mestre em Ciências na Área de Zoologia.

Orientador: Fernando Portella de Luna Marques 
Machado, Denis Jacob

Acanthobothrium Blanchard, 1848:

diversidade filogenética das linhagens parasitas de arraias de água doce.

$\mathrm{x}+87 \mathrm{p}$

Dissertação (Mestrado) - Instituto de Biociências da Universidade de São Paulo. Departamento de Zoologia.

1. Acanthobothrium

2. Sistemática

3. Homologia dinâmica

I. Universidade de São Paulo. Instituto de Biociências. Departamento de Zoologia.

\section{Comissão Julgadora:}

Prof. Dr.

Marcus Vinicius Domingues
Prof. Dr.

Taran Grant

Prof. Dr.

Fernando Portella de Luna Marques 
Com saudades, a tia Irma e aos amigos distantes. 
What is a master but a master student?

Neil Peart interview to "Rolling Stone", 2012 


\title{
Agradecimentos
}

\author{
Apoio financeiro
}

FAPESP, proc. no. 2009/13561-5

Apoio técnico e científico

Laboratório de Helmintologia Evolutiva, Dpto. de Zoologia, IB-USP

Laboratório de Sistemática Molecular, Dpto. de Zoologia, IB-USP

Serviços bibliotecários

Dione Seripiere, Museu de Zoologia da Universidade de São Paulo

Grégory Van Aelbrouk, Académie royale des Sciences, des Lettres et des Beaux-Arts de

Belgique

\section{Coleções consultadas}

Coleção Helmintológica do Instituto Oswaldo Cruz

Coleção de Helmintos, Museu de Zoologia da Universidade de São Paulo

Colección Nacional de Helmintos, Universidad Nacional Autónoma de México

Formação complementar

The Willi Hennig Society, 12th International workshop in Phylogenetic Methods, Xalapa,

México

\section{Participações especiais}

$\begin{array}{ll}\text { Prof. Dr. Almir Rogério } & \text { Prof. Dr. Leandro Assis } \\ \text { Dra. Cibele Bragagnolo } & \text { Maíra Concistré } \\ \text { Claudia Olivares } & \text { Dra. Sabrina Baroni } \\ \text { Veronica Mantovani Bueno } & \text { Natalia da Mata Luchetti } \\ \text { Marco Sena } & \text { Max Maronna }\end{array}$

Agradecimentos especiais

Profs. Drs. Gerardo Péres e Efrain De Luna, pelo coleguismo em terras estrangeiras

Mauro Cardoso Júnior, pela sua dissertação que serviu de base e inspiração para esta

Prof. Dr. Fernando Portella de Luna Marques, pela amizade e orientação

Profs. Drs. Sérgio Antonio Vanin, Silvio Shigueo Nihei e Ubirajara Ribeiro Martins, pela consultoria jurídica em assuntos nomenclaturais e taxonômicos

Prof. Dr. Taran Grant, por seus esclarecimentos a respeito da metodologia empregada Biodiversity Heritage Library (http: / / www . biodiversitylibrary.org/), pela iniciativa a ser seguida

Bianca da Hora, pelo apoio e companheirismo

Agradecemos a colaboração das Dras. Janine Caira e Caroline A. Fyler.

Somos gratos também aos membros suplentes da Comissão Julgadora, Profs. Drs. Sergio Antonio Vanin e Sir Jeffrey Jon Shaw. 


\section{Sumário}

1 Introdução geral 1

1.1 O papel de Acanthobothrium na Biogeografia Histórica Neotropical . . . . . . 2

1.2 Presente estado do conhecimento taxonômico e filogenético de Acanthobothrium 4

1.3 Objetivos gerais . . . . . . . . . . . . . . . . . . 5

1.4 Organização da dissertação . . . . . . . . . . . . . . . . . . . . . . 6

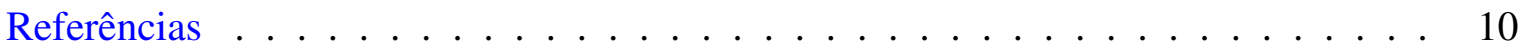

2 The forgotten origin of Acanthobothrium 11

Acknowledgements . . . . . . . . . . . . . . . . . . . . . . . 14

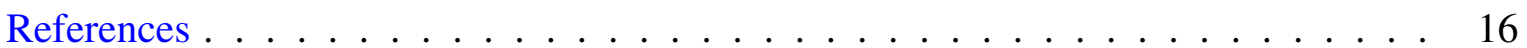

3 Diversification and species boundaries of Acanthobothrium 17

3.1 Introduction . . . . . . . . . . . . . . . . . . . 17

3.2 Material and methods . . . . . . . . . . . . . . . . . . 18

3.2.1 Taxonomic representation of marine tetraphyllideans . . . . . . . . . 18

3.2.2 Collection of freshwater stingray specimens . . . . . . . . . . . . . . . 19

3.2.3 Collection of cestode specimens . . . . . . . . . . . . . . . . . . . . 19

3.2.4 DNA extraction, amplification, and sequencing . . . . . . . . . . . 19

3.2 .5 Phylogenetic analysis . . . . . . . . . . . . . . . . . 21

3.3 Results . . . . . . . . . . . . . . . . . . . 26

3.3 .1 Molecular dataset . . . . . . . . . . . . . . . 26

3.3.2 Working hypothesis . . . . . . . . . . . . . . 26

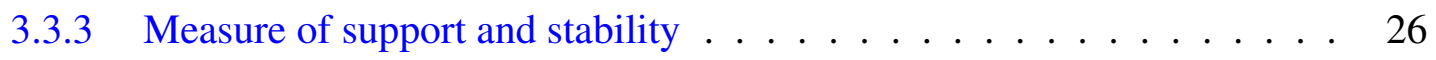

3.4 Discussion . . . . . . . . . . . . . . . . . . 28

3.4.1 On the relationship between Acanthobothrium and Uncibilocularis . . . 28

3.4.2 Freshwater Acanthobothrium and intra-specific variation . . . . . . . . 31

3.4.3 Conflicting patterns of host specificity . . . . . . . . . . . . 33

3.4.4 Phylogenetic relationships among freshwater Acanthobothrium . . . . 35

3.4.5 On the polyphyly of freshwater Acanthobothrium . . . . . . . . . . . 36

Acknowledgements . . . . . . . . . . . . . . . . . . 37

References . . . . . . . . . . . . . . . . . . . . 45 
4 Considerações finais $\quad 47$

4.1 A origem de Acanthobothrium . . . . . . . . . . . . . . . . . . . . 47

4.2 Acanthobothrium é monofilético? . . . . . . . . . . . . . . . . . 47

4.3 Clados negligenciados . . . . . . . . . . . . . . . . . . . 48

4.4 Relações filogenéticas entre Acanthobothrium dulcícolas . . . . . . . . . . . . . 49

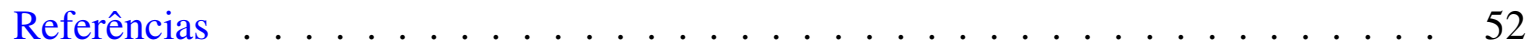

$\begin{array}{ll}\text { Resumo } & 53\end{array}$

$\begin{array}{ll}\text { Abstract } & 55\end{array}$

Anexos $\quad 57$

A.1 Collection of freshwater stingrays _ . . . . . . . . . . . . . . 59

A.2 Coleta e fixação do material biológico . . . . . . . . . . . . . . . 62

A.3 Preparação de lâminas de hologenóforos . . . . . . . . . . . . . . . . 63

A.4 Original cestode material collected in South America . . . . . . . . . . . . . 64

A.5 Protocolo otimizado para extração de DNA genômico com DNAdvance ${ }^{\mathrm{TM}}$. . 71

A.6 Protocolo otimizado para purificação de DNA genômico com AMPure ${ }^{\mathrm{TM}}$ kit . . 74

A.7 Sequence data acquired from GenBank . . . . . . . . . . . . . . . . 75

A.8 Sequence data acquired from Fyler (2009) $\ldots \ldots \ldots \ldots$

A.9 Strict consensus tree . . . . . . . . . . . . . . . . 83

A.10 Cladogram with branch lengths representing the number of transformations . . 85

A.11 Descrição dos anexos eletrônicos . . . . . . . . . . . . . . . . 87 


\section{Lista de Tabelas}

3.1 Primers used for PCR amplification and cycle sequencing . . . . . . . . . . . 21

3.2 Tree lengths from the OA combined analysis . . . . . . . . . . . . . 26

3.3 Mickevich-Farris Extra Steps Index (MFES) calculations . . . . . . . . . . 28

A.1 Potamotrygonid stingray species and localities sampled in this study . . . . . 59

A.2 Original cestode material collected in South America . . . . . . . . . . . . . . 64

A.3 GenBank data for Proteocephalidea and Acanthobothrium . . . . . . . . . . . . 75

A.4 Specimens of Acanthobothrium sequenced by Fyler (2009) . . . . . . . . . . . 76 


\section{Lista de Figuras}

3.1 Collection sites of potamotrygonid specimens . . . . . . . . . . 20

3.2 Flow chart showing the main steps of the combined DO search strategy . . . . 23

3.3 Main steps of the Goodman-Bremer calculation . . . . . . . . . . . . . 25

3.4 Strict consensus of the six trees of parameter $2: 1: 1: 1 \ldots \ldots \ldots \ldots$

3.5 Sensitivity plot . . . . . . . . . . . . . . . . . . 29

3.6 Possible scenarios for the freshwater invasion . . . . . . . . . . . . 38

A.1 Complete strict consensus tree with support and stability measures . . . . . 83

A.2 Cladogram with branch lengths proportional to the number of transformations. . 85 

$\prod_{\text {capítulo }} 1$

\section{Introdução geral}

Acanthobothrium Blanchard, 1848 (Eucestoda: Tetraphyllidea: Onchobothriidae) é um helminto caracterizado por botrídios triloculados que portam um par de ganchos bífidos (Southwell, 1925). Como os demais tetrafilídeos, este helminto atinge a maturidade no interior das válvulas espirais de tubarões e arraias (Campbell \& Beveridge, 2002; Zschoche et al., 2011). Acanthobothrium foi alvo de diversas revisões (e.g., Linton, 1925; Baer, 1948; Goldstein, 1967; Williams, 1969) motivadas por interesses diversos, entre os quais desponta seu número crescente de espécies. Por exemplo, Goldstein (1967) reportou 44 espécies válidas e, apenas dois anos mais tarde, Williams (1969) reportou 69 espécies válidas. Especula-se que atualmente hajam mais de 200 espécies nominais de Acanthobothrium (Campbell \& Beveridge, 2002; Ivanov, 2005; Fyler, 2009; Cardoso, 2010; Zschoche et al., 2011). A verificação do status taxonômico destas espécies e do número exato de espécies válidas para este gênero aguarda uma revisão taxonômica que certamente só será alcançada através do esforço conjunto de diversos pesquisadores.

A variação morfológica inter e intraespecífica de Acanthobothrium é elevada e constitui um fator complicante para a resolução taxonômica do gênero. De acordo com Fyler (2009) e Zschoche et al. (2011), Acanthobothrium está representado por formas que variam desde os maiores aos menores membros de Onchobothriidae (e.g., Acanthobothrium macracanthum Southwell, 1925, que atinge cerca de $21 \mathrm{~cm}$ de comprimento total, e A. gnomus Reyda \& Caira, 2006, com aproximadamente $1 \mathrm{~mm}$ de comprimento total). No gênero estão inclusas desde espécies com apenas três proglótides (e.g., Acanthobothrium tripartium Williams, 1969) a espécies com mais de 950 proglótides (e.g., Acanthobothrium grandiceps Yamaguti, 1952). Também é grande a diversidade de formas e tamanhos dos ganchos (Cardoso, 2010). Uma vez que raramente são encontrados carácteres diagnósticos para os membros de Acanthobothrium, suas espécies são muitas vezes delimitadas por combinações únicas de carácteres amplamente difundidos entre membros do gênero e demais tetrafilídeos (Fyler, 2009). Grande parte destes carácteres são baseados na média ou nos limites de distribuição 
de variáveis quantitativas, como comprimento total ou número de testículos (e.g., Brooks \& Amato, 1992; Berman \& Brooks, 1994; Healy, 2006; Caira et al., 2007), resultando na definição ambígua de muitas espécies nominais (Cardoso, 2010).

Além de seu elevado número de espécies e plasticidade fenotípica, Acanthobothrium impressiona por sua distribuição cosmopolita, ampla variedade de hospedeiros e elevada especificidade. Estima-se que aproximadamente 130 espécies de Acanthobothrium parasitem membros de cinco das seis ordens de arraias (i.e., Myliobatiformes, Rajiformes, Rhiniformes, Rhinobatiformes e Torpediniformes) e cerca de 80 espécies sejam encontradas em cinco das oito ordens de tubarões (i.e., Carcharhiniformes, Heterodontiformes, Orectolobiformes, Pristiophoriformes e Squatiniformes; veja Fyler, 2009). As espécies marinhas de Acanthobothrium apresentam alta especificidade a seus hospedeiros (sensu Euzet \& Combes, 1980), o que é consistente com o padrão observado para os demais oncobotriídeos, que estão entre os grupos de parasitas com maior especificidade a seus hospedeiros (Caira \& Jensen, 2001). Nos rios da América do Sul, espécies de Acanthobothrium são encontradas parasitando membros de Potamotrygonidae (Chondrichthyes: Myliobatoidei).

\subsection{O papel de Acanthobothrium na Biogeografia Histórica Neotropical}

Os potamotrigonídeos são endêmicos da região Neotropical e constituem os únicos elasmobrânquios estenoalinos a viverem exclusivamente na água doce. A família compreende mais de 20 espécies válidas e pelo menos 10 novas espécies a serem descritas (Marques, 2000; de Carvalho et al., 2003; Rosa et al., 2008; da Silva \& de Carvalho, 2011b,a; de Carvalho \& Lovejoy, 2011a; de Carvalho \& Ragno, 2011; de Carvalho et al., 2011), distribuídas em quatro gêneros: Paratrygon Dumeril, 1865; Potamotrygon Garman, 1913; Plesiotrygon Rosa, Castello \& Thorson, 1987; e Heliotrygon de Carvalho \& Lovejoy, 2011. Os potamotrigonídeos podem ser encontrados nas principais bacias hidrográficas da América do Sul, incluindo as bacias dos rios Atrato e Magdalena (Colombia), Orinoco (Venezuela), Lago de Maracaibo (Venezuela), Parnaíba (MA, PI), Uruguai, Paraná e Paraguai, além da bacia Amazônica (Ecuador, Colombia, Peru, Bolívia e Brasil) e dos rios das Guianas e do Suriname (Thorson, 1970; Thorson et al., 1978, 1983; Rosa, 1985; Nishida, 1990; Lovejoy, 1996; de Carvalho et al., 2003; Rosa et al., 2008).

A convoluta história biogeográfica dos potamotrigonídeos e seu impacto na diversificação de suas linhagens associadas de parasitas fazem deste sistema um interessante modelo para estudos em biogeografia e associação histórica. Dentro deste contexto, Brooks et al. (1981) foram pioneiros em explorar o potencial de linhagens de parasitas em oferecerem informações 
a respeito da invasão da água doce pelo ancestral dos potamotrigonídeos e a subsequente diversificação das arraias de água doce. Empregando dados morfológicos provenientes de parasitas de potamotrigonídeos (i.e., Tetraphyllidea: Onchobothriidae: Acanthobothrium e Potamotrygonocestus, Tetraphyllidea: Phyllobothiidae: Rhinebothrium, Rhinebothroides; e Nematoda: Eutetrarhynchus e Echinocephalus), Brooks et al. (1981) propuseram que os potamotrigonídeos seriam grupo-irmão de "urolofídeos" e teriam colonizado a América do Sul a partir do Oceano Pacífico. Observe que, apesar do uso do termo "urolofídeos", Brooks et al. referem-se a membros de Urotrygonidae (Urobatis e Urotrygon). De acordo com esta hipótese, os potamotrigonídeos teriam sido confinados no continente a $90 \mathrm{Ma}$ devido à orogênese dos Andes. Esta hipótese ficou conhecida como "hipótese Pacífico/urolofídeos" e passou a ser uma contribuição inovadora para Biogeografia Histórica (Straney, 1982) e um grande exemplo para as salas de aula (Blair, 1994). Desde a sua publicação, porém, esta hipótese tem sido extensivamente questionada com base na inadequação dos métodos e, principalmente, na fragilidade dos dados parasitológicos empregados (e.g., Caira, 1990; Lovejoy, 1997).

Diversos aspectos da análise conduzida por Brooks et al. são crípticos e dificultam a replicação de seus resultados. Por exemplo, o grupo externo de suas análises não foi explicitado e as matrizes de carácteres morfológicos empregados nunca foram publicadas integralmente. Ademais, a própria representação dos cladogramas obtidos dá margem a críticas. Por exemplo, o cladograma proposto para Acanthobothrium mostra um clado contendo as quatro espécies então conhecidas para o gênero e parasitas de potamotrigonídeos (Acanthobothrium terezae Rego \& Dias, 1976; Acanthobothrium amazonensis Mayes, Brooks \& Thorson, 1978; Acanthobothrium quinonesi Mayes, Brooks \& Thorson, 1978; e Acanthobothrium regoi Brooks, Mayes \& Thorson, 1981a) como grupo-irmão de Acanthobothrium cartagenensis Brooks \& Mayes, 1980 do Caribe e Acanthobothrium holorhini Alexander, 1953 do sul da California. As demais 59 espécies de Acanthobothrium analisadas por Brooks et al. foram representadas como grupo-irmão do clado A. holorhini + linhagens dulcícolas de Acanthobothrium em um nó sem resolução.

A primeira hipótese concorrente a Brooks et al. foi levantada por Lovejoy $(1996,1997)$ e Lovejoy et al. (1998) com base em dados provenientes dos próprios hospedeiros. Estes autores empregaram dados morfológicos de diversos grupos de arraias para proporem que os potamotrigonídeos derivaram de um ancestral comum compartilhado com linhagens amfiAmericanas de Himantura, habitantes do mar do Caribe ("hipótese Caribe/Himantura"). Marques (2000) corroborou esta hipótese com dados morfológicos e moleculares de parasitas e arraias, respectivamente. Segundo estes autores, transgressões marinhas durante o Mioceno teriam possibilitado a invasão do América do Sul há aproximadamente $20 \mathrm{Ma}$. O subsequente isolamento do ancestral potamotrigonídeo teria sido resultado de alterações no escoamento do 
paleo-Orinoco-Amazonas, há aproximadamente $11 \mathrm{Ma}$.

A hipótese mais recente quanto à origem dos potamotrigonídeos foi proposta por de Carvalho et al. (2004) com base na morfologia de arraias viventes e fósseis. Os autores concordam que transgressões marinhas na região do Caribe seriam o mecanismo responsável pela colonização da América do Sul pelos potamotrigonídeos. Entretanto, a data do evento proposta pelos autores é muito mais antiga, no mínimo durante o Eoceno, há $50 \mathrm{Ma}$ ou mais. Os autores ainda refutaram a hipótese de que o clado Himantura pacifica $+H$. schmardae é grupo irmão de Potamotrygonidae, propondo que as arraias de água doce compartilham um ancestral comum com ("Dasyatidae"+(Gymnuridae+Myliobatidae)).

Atualmente, há consenso na literatura quanto à monofilia de Potamotrygonidae assim como quanto a transgressões marinhas na região do Caribe terem sido o mecanismo responsável pela invasão da América do Sul pelas arraias de água doce. Entretanto, a data de origem e o grupo-irmão desta família de elasmobrânquios permanecem em disputa. Dentro deste contexto, acredita-se que a resolução da taxonomia e filogenia de tetrafilídeos pode vir a esclarecer a origem dos potamotrigonídeos (Reyda, 2007) e ainda que Acanthobothrium poderá ser empregado como modelo nos estudos de associações históricas entre parasitas e hospedeiros (Fyler, 2009).

\subsection{Presente estado do conhecimento taxonômico e filogenético de Acanthobothrium}

Os avanços mais recentes em relação à taxonomia de Acanthobothrium de água doce se devem às descrições de A. ramiroi por Ivanov (2005) e A. peruviense por Reyda (2008) e pela revisão ainda não publicada de Cardoso (2010). Segundo Cardoso, a maioria das espécies de Acanthobothrium, em particular as espécies parasitas de potamotrigonídeos, foi descrita com base em um número restrito de exemplares provenientes da amostragem de poucos hospedeiros de localidades geograficamente distantes umas das outras. Para Cardoso, esta prática tem conduzido pesquisadores a denominar novos táxons sob a premissa de que estas linhagens exibem pouca variação morfológica, uma vez que algumas especies foram erigidas com base em descontinuidades morfométrícas em relação a outras já atribuidas ao gênero. Afim de averiguar a real plasticidade fenotípica de espécies dulcícolas de Acanthobothrium, Cardoso amostrou 10 espécies válidas e 14 possíveis espécies novas de potamotrigonídeos, totalizando 649 espécimes de potamotrigonídeos provenientes de 10 sub-bacias hidrográficas da América do Sul. Esta ampla amostragem permitiu que Cardoso observasse uma variação morfológica intraespecífica jamais documentada para membros de Acanthobothrium. 
Cardoso advoga que somente cinco espécies de Acanthobothrium são discerníveis morfologicamente no ambiente de água doce: A. terezae (sinônimo júnior: A. ramiroi), A. quinonesi (sinônimos:A. regoi e A. peruviense), A. amazonensis e duas novas espécies ainda não descritas, às quais o autor se refere como Acanthobothrium sp. 1 e Acanthobothrium sp. 2. Cardoso verificou ainda que estas cinco espécies de Acanthobothrium parasitam 27 espécies de potamotrigonídeos em quase todas as sub-bacias hidrográficas da América do Sul, demonstrando um padrão distinto de seus congêneres marinhos que são considerados altamente específicos a seus hospedeiros (Ghoshroy \& Caira, 2001; Campbell \& Beveridge, 2002). A alta plasticidade fenotípica e baixa especificidade observadas em espécies de Acanthobothrium de água doce pode ser resultado de características específicas do sistema potamotrigonídeos/parasitas (ver Reyda \& Marques, 2011) ou um artefato taxonômico relacionado ao número restrito de espécimens empregados na descrição de espécies marinhas, muitas vezes obtidos por coletas distantes umas das outras e/ou com baixa representatividade de espécies de hospedeiros. Entretanto, Cardoso recomenda que novas fontes de dados (e.g., molecular) sejam adicionadas para circunscrever de forma mais robusta as espécies de água doce de Acanthobothrium e entender melhor as peculiaridades deste sistema em relação ao ambiente marinho.

Impressionantemente, três décadas após o trabalho seminal de Brooks et al. sobre este sistema parasita/hospedeiro, as linhagens de Acanthobothrium parasitas de potamotrigonídeos permanecem negligenciados dentro de um contexto filogenético. Olson et al. (2001), Caira et al. (2005) e Healy et al. (2009) são os únicos autores a terem publicado filogenias incluindo membros de Acanthobothrium, no entanto, restringindo-se à inclusão de uma única espécie não descrita parasita de Dasyatis longus (Garman, 1980). Fyler (2009) foi a primeira autora a fazer uma análise extensa de Acanthobothrium dentro de um contexto filogenético, porém a representatividade de linhagens dulcícolas em sua análise estava restrita a apenas três terminais representando duas espécies nominais parasitas de poatamotrigonídeos (A. terezae e A. ramiroi).

\subsection{Objetivos gerais}

Dentro deste contexto, este trabalho visa:

1. Avaliar o status taxonômico das espécies nominais de Acanthobothrium parasitas de potamotrigonídeos com base em sua monofilia recíproca e consistência morfológica; and

2. Identificar a posição relativa de linhagens monofiléticas de Acanthobothrium dulcícolas em relação a seus congêneres marinhos. 


\subsection{Organização da dissertação}

Além da contextualização apresentada neste capítulo, a dissertação está dividida em mais três capítulos com objetivos independentes, interrrelacionados e complementares.

O Capítulo 2, "The forgotten origin of Acanthobothrium Blanchard, 1848 (Eucestoda: Tetraphyllidea: Onchobothriidae)", procura resolver conflitos nomenclaturais em torno do nome genérico Acanthobothrium afim de delinear adequadamente o gênero em estudo.

O Capítulo 3, "Diversification and species boundaries of Acanthobothrium (Eucestoda: Tetraphyllidea: Onchobothriidae) in South American freshwater stingrays (Myliobatiformes: Potamotrygonidae)", aborda os objetivos específicos desta contribuição através da análise do posicionamento filogenético de linhagens de Acanthobothrium com base na otimização direta de dados moleculares.

Finalmente, o Capítulo 4 traz as "Considerações finais" deste estudo, destacando questões taxonômicas e evolutivas levantadas durante os capítulos anteriores.

\section{Referências}

Alexander, C. G. 1953. Five new species of Acanthobothrium (Cestoda: Tetraphyllidea) from southern California rays. Journal of Parasitology 39: 481-486.

Baer, J. B. 1948. Contributions a l'étude des cestodes de Sélaciens. I-IV, Bulletin de la Société neuchateloise des Sciences naturelles 71: 63-122.

Berman, R. \& D. R. Brooks. 1994. Escherbothrium molinae n. gen. et n. sp. (Eucestoda: Tetraphyllidea: Triloculariidae) in Urotrygon chilensis (Chondrichthyes: Myliobatiformes: Urolophidae) from the Gulf of Nicoya, Costa Rica. The Journal of Parasitology 80(5): 775780.

Blair, D. 1994. So many parasites and so little time! Review of Parascript: Parasites and the Language of Evolution, by D. R. Brooks and D. A. McLennan. Systematic Biology 43: 296298.

Brooks, D. R. \& J. F. R. Amato. 1992. Cestode parasites in Potamotrygon motoro (Natterer) (Chondrichthyes: Potamotrygonidae) from Southwestern Brazil, including Rhinebothroides mclennanae n. sp. (Tetraphyllidea: Phyllobothriidae), and a revised host-parasite checklist for helminths inhabiting Neotropical freshwater stingrays. The Journal of Parasitology 78(3): 393-398.

Brooks, D. R. \& M. A. Mayes. 1980. Cestodes in four species of euryhaline stingrays from Colombia. Proceedings of the Helminthological Society of Washington 47: 22-29. 
Brooks, D. R.; T. B. Thorson \& M. A. Mayes. 1981. Freshwater stingrays (Potamotrygonidae) and their helminth parasites: testing hipotesis of evolution and coevolution. Em: Advances in cladistics. Funk, V. A. \& D. R. Brooks (eds.). New York: New York Botanical Garden, pp. 145-175.

Brooks, D. R.; M. A. Mayes \& T. B. Thorson. 1981a. Systematic review of cestodes infecting freshwater stingrays (Chondricthyes: Potamotrygonidae) including four new species from Venezuela. Proceedings of the Helminthological Society of Washington 48(1): 43-64.

Caira, J. N. 1990. Metazoan parasites as indicators of elasmobranch biology. Elasmobranchs as living resources: Advances in the biology, ecology, systematics, and the status of the fisheries, NOAA Technical Report 90: 71-96.

Caira, J. N. \& K. Jensen. 2001. An investigation of the co-evolutionary relationships between onchobothriid tapeworms and their elasmobranch hosts. International Journal of Parasitology 31: 960-975.

Caira, J. N.; J. D. Mega \& T. R. Ruhnke. 2005. An unusual blood sequestering tapeworm (Sanguilevator yearsleyi n. gen., n. sp.) from Borneo with description of Cathetocephalus resendezi $\mathrm{n}$. sp. from Mexico and molecular support for the recognition of the order Cathetocephalidea (Platyhelminthes: Eucestoda). International Journal for Parasitology 35: 1135-1152.

Caira, J. N.; F. B. Reyda \& J. D. Mega. 2007. A revision of Megalonchos Baer \& Euzet, 1962 (Tetraphyllidea: Onchobothriidae), with the description of two new species and transfer of two species to Biloculuncus Nasin, Caira \& Euzet, 1997. Systematic Parasitology 67: 211223.

Campbell, R. A. \& I. Beveridge. 2002. The genus Acanthobothrium (Cestoda: Tetraphyllidea: Onchobothriidae) parasitic in Australian elasmobranch fishes. Invertebrate Systematics 16: 237-344.

Cardoso Jr., M. 2010. Taxonomia das linhagens de Acanthobothrium van Beneden, 1850 (Eucestoda: Tetraphyllidea) parasitas de Potamotrygonidae (Chondrichthyes: Myliobatiformes). Diss. de mestrado. São Paulo: Universidade de São Paulo. 69 pp.

da Silva, J. P. C. B. \& M. R. de Carvalho. 2011. A new species of Neotropical freshwater stingray of the genus Potamotrygon Garman, 1877 from the Río Madre de Díos, Peru (Chondrichthyes: Potamotrygonidae). Papéis Avulsos de Zoologia 51(8): 139-154.

da Silva, J. P. C. B. \& M. R. de Carvalho. 2011. A taxonomic and morphological redescription of Potamotrygon falkneri Castex \& Maciel, 1963 (Chondrichthyes: Myliobatiformes: Potamotrygonidae). Neotropical Ichthyology 9(1): 209-232.

de Carvalho, M. R. \& N. R. Lovejoy. 2011. Morphology and phylogenetic relationships of a remarkable new genus and two new species of Neotropical freshwater stingrays from the Amazon basin (Chondrichthyes: Potamotrygonidae). Zootaxa 2776: 13-48. 
de Carvalho, M. R. \& N. R. Lovejoy. 2011. Morphology and phylogenetic relationships of a remarkable new genus and two new species of neotropical freshwater stingrays from the amazon basin (Chondrichthyes: Potamotrygonidae). Zootaxa 2776: 13-48.

de Carvalho, M. R. \& M. P. Ragno. 2011. An unusual, dwarf new species of Neotropical freshwater stingray, Plesiotrygon nana sp. nov., from the upper and mid Amazon river basin: the second species of Plesiotrygon (Chondrichthyes: Potamotrygonidae). Papéis Avulsos de Zoologia 51(7): 101-138.

de Carvalho, M. R.; N. R. Lovejoy \& R. S. Rosa. 2003. Family Potamotrygonidae (river stingrays). Em: Checklist of the freshwater fishes of South and Central America. Reis, R. E.; S. O. Kullander \& C. J. Ferraris (eds.). EDIPUCRS, pp. 22-28.

de Carvalho, M. R.; J. G. Maisey \& L. Grande. 2004. Freshwater stingrays of the Green River formation of Wyoming (early Eocene), with the description of a new genus and species and an analysis of its phylogenetic relationships (Chondrichthyes: Myliobatiformes). Bulletin of the American Museum of Natural History 284: 1-136.

de Carvalho, M. R.; M. H. S. Perez \& N. R. Lovejoy. 2011. Potamotrygon tigrina, a new species of freshwater stingray from the upper Amazon basin, closely related to Potamotrygon schroederi Fernandez-Yépez, 1958 (Chondrichthyes: Potamotrygonidae). Zootaxa 2827: 130.

Duméril, A. H. A. 1865. Histoire naturelle des poissons ou ichthyologie générale. Paris, Roret, p. 740. URL: http: / / www.biodiversitylibrary.org/item/28354.

Euzet, L. \& C. Combes. 1980. Les problemes de l'espèce chez les animaux parasites. Bulletin de la Societé Zoologique de France 3: 239-285.

Fyler, C. A. 2009. Systematics, biogeography and character evolution in the tapeworm genus Acanthobothrium van Beneden, 1850. Tese de doutorado. Storrs: University of Connecticut. $168 \mathrm{pp}$.

Garman, S. 1913. The Plagiostomia (sharks, skates and rays). Memoirs of the Museum of Comparative Zoology 36: 1-515, 77 pls.

Ghoshroy, S. \& J. N. Caira. 2001. Four new species of Acanthobothrium (Cestoda: Tetraphyllidea) from the whiptail stingray Dasyatis brevis in the Gulf of California, Mexico. The Journal of Parasitology 87(2): 354-372.

Goldstein, R. J. 1967. The genus Acanthobothrium Van Beneden, 1849 (Cestoda: Tetraphyllidea). The Journal of Parasitology 53(3): 455-483.

Healy, C. J. 2006. A revision of selected Tetraphyllidea (Cestoda): Caulobothrium, Rhabdotobothrium, Rhinebothrium, Scalithrium, and Spongiobothrium. Tese de doutorado. Storrs: University of Connecticut. $234 \mathrm{pp}$.

Healy, C. J.; J. N. Caira; K. Jensen; B. L. Webster \& T. Littlewood. 2009. Proposal for the new tapeworm order Rhinebothriidea. International Journal for Parasitology 39: 497-511. 
Ivanov, V. A. 2005. A new species of Acanthobothrium (Cestoda: Tetraphyllidea: Onchobotriidae) from the ocellate river stigray, Potamotrygon motoro (Chondrichthyes: Potamotrygonidae), in Argentina. Journal of Parasitology 91: 390-396.

Linton, E. 1925. Notes on cestode parasites of sharks and skates. Proceedings of the United States National Museum 64: 1-114.

Lovejoy, N. R. 1996. Systematic of myliobatoid elasmobranchs: whith emphasis on phylogeny and historical biogeography of Neotropical freshwater stingrays (Potamotrigonidae: Rajiformes). Zoological Journal of the Linnean Society 117: 207-257.

Lovejoy, N. R. 1997. Stingrays, parasites, and neotropical biogeography: a closer look at Brooks et al.'s hypothesis concerning the origins of neotropical freshwater rays (Potamotrygonidae). Systematic Biology 46: 218-230.

Lovejoy, N. R.; E. Bermingham \& A. P. Martin. 1998. Marine incursion into South America. Nature 396: 421-422.

Marques, F. P. L. 2000. Evolution of Neotropical freshwater stingrays and their parasites: taking into account space and time. Tese de doutorado. Toronto: University of Toronto. $325 \mathrm{pp}$.

Mayes, M. A.; D. R. Brooks \& T. B. Thorson. 1978. Two new species of Acanthobothrium van Beneden 1849 (Cestoda; Tetraphyllidea) from freshwater stingrays in South America. Journal of Parasitology 64(5): 838-841.

Nishida, K. 1990. Phylogeny of the suborder Myliobatoidei. Memoirs of the Faculty of Fisheries, Hokkaido University 37: 1-108.

Olson, C. B.; D. Timothy; T. Littlewood; R. A. Bray \& J. Mariaux. 2001. Interrelationships and evolution of the tapeworms (Platyhelminthes: Cestoda). Molecular Phylogenetics and Evolution 19(3): 443-467.

Rego, A. A. \& A. P. L. Dias. 1976. Etudos de cestoides de peixes do Brasil, 3a nota: Cestoides de raias fluviais Paratrygonidae. Revista Brasileira de Biologia 36: 941-956.

Reyda, F. B. 2007. Patterns of diversity and host specificity in the cestodes of Neotropical freshwater stingrays. Tese de doutorado. Storrs: University of Connecticut. $215 \mathrm{pp}$.

Reyda, F. B. 2008. Intestinal helminths of freswater stingrays in southeastern Peru, and a new genus and two new species of cestode. Journal of Parasitology 94(3): 684-699.

Reyda, F. B. \& J. N. Caira. 2006. Five new species of Acanthobothrium (Cestoda: Tetraphyllidea) from Himantura uarnacoides (Myliobatiformes: Dasyatidae) in Malaysian Borneo. Comparative Parasitology 73(1): 49-71.

Reyda, F. B. \& F. P. L. Marques. 2011. Diversification and species boundaries of Rhinebothrium (Cestoda; Rhinebothriidea) in South American freshwater stingrays (Batoidea; Potamotrygonidae). PLoS ONE 6(8): e22604. DOI: 10 . 1371 / journal. pone.0022604. 
Rosa, R. S. 1985. A systematic revision of the South American freshwater stingrays (Chondrichthyes: Potamotrigonidae). Tese de doutorado. Williamsburg: The College of Willian e Mary. 542 pp.

Rosa, R. S.; H. Castello \& T. B. Thorson. 1987. Plesiotrygon iwamae, a new genus and species of neotropical freshwater stingray. Copeia 2: 447-458.

Rosa, R. S.; M. R. de Carvalho \& C. D. A. Wanderlay. 2008. Potamotrygon boesemani (Chondrichthyes: Myliobatiformes: Potamotrygonidae), a new species of Neotropical freshwater stingray from Surinam. Neotropical Ichthyology 6: 1-8.

Southwell, T. 1925. A monograph on the Tetraphyllidea with notes on related cestodes. Memoirs of the Liverpool School of Tropical Medicine (New Series) 2: 1-368.

Straney, D. O. 1982. Review of Advances in Cladistics: Proceedings of the Fist Meeting of the Willi Hennig Society, edited by V.A. Frank and D. R. Brooks. Systematic Zoology 31: 337341.

Thorson, T. B. 1970. Freshwater stingrays, Potamotrygon spp.: failure to concentrate urea when exposed to saline medium. Life Science 9: 893-900.

Thorson, T. B.; R. M. Wotton \& T. A. Georgi. 1978. Rectal gland of freshwater stingrays, Potamotrygon spp. (Chondricthyes: Potamotrygonidae). Biological Bulletin 154(3): 508516.

Thorson, T. B.; D. R. Brooks \& M. A. Mayes. 1983. The evolution of freshwater adaptation in stingrays. National Geographic Research Report 15: 663-694.

Williams, H. H. 1969. The genus Acanthobothrium Beneden 1849 (Cestoda: Tetraphyllidea). Nytt Magazine of Zoology 17: 1-56.

Yamaguti, S. 1952. Studies on the helminth fauna of Japan. Part 49. Cestodes of fishes, II. Acta Medicinae Okayama 8: 1-76.

Zschoche, M.; J. N. Caira \& C. A. Fyler. 2011. A new species of Acanthobothrium van Beneden, 1850 (Tetraphyllidea: Onchobothriidae) from Pastinachus atrus (Macleay) (Batoidea: Dasyatidae) in Australian waters, with a reassessment of the host associations of Acanthobothrium spp. parasitising Pastinachus spp. Systematic Parasitology 78: 109-116. 


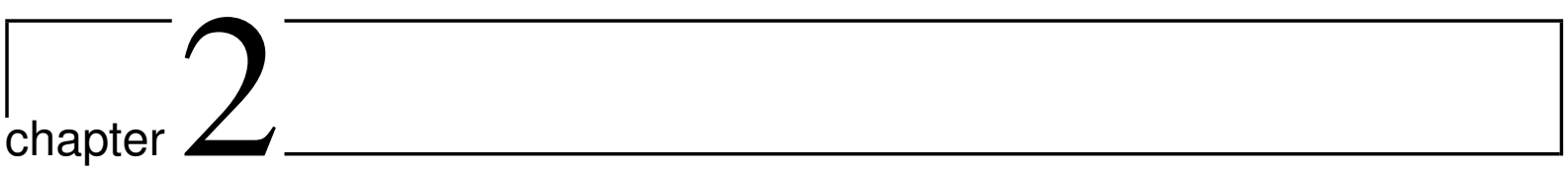

\section{The forgotten origin of Acanthobothrium}

\section{Blanchard, 1848 (Eucestoda: Tetraphyllidea: Onchobothriidae)}

The genus Acanthobothrium consists of an assemblage of cosmopolitan onchobothriid tapeworm parasites of chondrichthyan fishes. Despite its clear diagnostic features, which includes a scolex with four septate bothridia bearing three loculi and a pair of as/symmetric bipronged hooks, this genus is represented by worms that possess a range of morphologies and host lineages (e.g., rays, skates, guitarfishes, and sharks; Campbell and Beveridge, 2002; Zschoche et al., 2011). The wide distributional range of this group, its diverse morphology, and a somewhat long and intricate taxonomic history may account for the fact that to date no absolute number of valid species, of potentially more than 200 nominal species, can be assigned to this genus with certainty. Therefore, a taxonomic revision of this group is overdue; a task that certainly will only be accomplished by collaborative efforts of cestodologists given the widespread distribution of its members and the necessity of collecting new material to verify host identity and/or re-access species' morphology. It is not our purpose to provide such a revision. However, it is our intention to clarify the authorship, date of publication, type species, and type host of Acanthobothrium. To the best of our understanding, these have been mistakenly assigned throughout the taxonomic history of the genus.

Despite several taxonomic reviews (e.g., Linton, 1925; Baer, 1948; Goldstein, 1967; Williams, 1969), there is still no consensus on the authority of Acanthobothrium. Nomenclatur Zoologicus (Neave, 1939, Vol. I, p. 11) registers two entries for the genus-group name Acanthobothrium, attributed to Blanchard (1849) and Van Beneden (1849), which means that at least since 1939 the authorship of the genus is ambiguous. Contemporary authors disregard Blanchard as the author of Acanthobothrium and assign two possible dates for Van Beneden's 
authorship of the genus. For some (e.g., Khalil et al., 1994; Reyda and Caira, 2006; VardoZalik and Campbell, 2011), Acanthobothrium should be assigned to Van Beneden (1849), whereas others (e.g., Jensen and Caira, 2008; Twohig et al., 2008; Fyler, 2011; Zschoche et al., 2011) implicitly assume that the genus should only be recognized as valid by the more detailed description provided by Van Beneden (1850).

To our knowledge, the first usage of the name Acanthobothrium was by Blanchard (1848: 364) in the legend of Plate 12, Fig. 9, in which it reads "ACANTHOBothrie Couronné (Acanthobothrium coronatum), pour montrer la forme de la tête, la forme générale du corps, et le trajet dos tubes intestinaux." We consider that the name A. coronatum was made available by Blanchard since this nomenclatural act satisfy the provisions of Article 11 and 12 of the ICZN (see ICZN Art. 12.2.7 for information about species-group names published before 1931 in association with an illustration). Despite the abscence of a detailed description for the new species, Blanchard (1848) withholds the authorship of $A$. coronatum for being the first published work to name it (ICZN Art. 23.1). It is important to note that the availability of a new speciesgroup name is not dependent on the availability of the genus-group name (ICZN Art. 11.9.3.1). However, if this species-group name is available, so is the genus-group name to which it is related (see ICZN Art. 12 and 12.2.5). Thus, Blanchard (1848) also withholds the authorship of the genus Acanthobothrium.

In February of the next year, Blanchard (1849: 121-122) provided the first detailed description of the "Genre ACANTOBOTHRIE (Acanthobothrium)" in which the author cited "Bothriuocephali onchobothrii Rud." as its type species. In the same month (date confirmed by Muquardt, 1849), Van Beneden (1849: 191) indicated a different type species for the genus using the term "Acanthobothrium n. gen. Bothr. bifurcatus" in a list of genera he included in "Bothroïdes." On the second revision of Acanthobothrium and A. coronatum, Van Beneden (1850: 129) cited “A. coronatum Rud." as the type of Acanthobothrium. With such confusion on the first works dealing with Acanthobothrium, it is not suprising that the type species of the genus is currently ambiguous. For example, while Yamaguti (1959: 83) claims that the type species of Acanthobothrium is "A. coronatum (Rud., 1819) van Beneden, 1849 (Pl. 21, Fig. 163), syn. Bothriocephalus bifurcatus Leuckart, 1819”, Campbell and Beveridge (2002: 239) state that the type species is "Bothriocephalus coronatus Rudolphi, 1819 by original designation." However, none of the aforementioned works published after Blanchard (1848) are valid nomenclatural acts regarding the typification of Acanthobothrium. Since there were no other species attributed to Acanthobothrium in 1848, it is clear that A. coronatum shall be considered the type species for being the only species name related to the genus when it was created (ICZN Art. 68).

The above leads us to another issue, which concerns the current valid name of $A$. coronatum. We understand that the stability of the name-bearing type implies that the type species must 
always be referred to as its original combination (ICZN Art. 61; see also Art. 67.1.2 and Recommendation 67B). Nevertheless, understanding the intricate taxonomic history of $A$. coronatum is crucial for understanding the concept of Acanthobothrium and of this species itself.

The first revision of $A$. coronatum was provided by Blanchard (1849: 122-124), with a list of synonyms including "Taenia raiae batis" Rudolphi (1810), Bothriocephalus coronatus Rudolphi, 1819, and Bothriocephalus bifurcatus Leuckart, 1819. Bothriocephalus bifurcatus was erected by Leuckart (1819: 30-32) who considered Taenia corollata Abildgaard, 1790 as its senior synonym. Abildgaard (1790: 62-63) provided a description of T. corollata consistent with a member of Acanthobothrium and identified "Rajæ Batis" (Raja batis L.) as the type host of his new species (see Abildgaard, 1790: 63; in which you should read "LocUs. Inter valvulas cochlidiales intestini Rajæ Batis"). The name B. corollatus was previously used by Rudolphi (1819: 485-486). This may have provoked Leuckart to assign his species in a different species group name. Bothriocephalus bifurcatus was selected for the new species-group name giving into consideration its bipronged hooks. The establishment of $B$. bifurcatus as a junior synonym of $A$. coronatum results in a new combination, A. corollatum (Abildgaard, 1790), following the oldest available name for this taxon, T. corollata (ICZN Art. 23.3).

Williams (1969: 5) had previously suggested that "in view of the numerous problems connected with the specific name 'corollatus' relative to Tetrarhynchide (...) it may be advisable to ignore the name $T$. corollata Abildgaard, 1793 in studies of A. coronatum" (sic). Note that Williams (1969: 5) is probably referring to Abildgaard (1790) when he writes "Abildgaard, 1793". Moreover, Williams (1969: 5) advocated that "the host list given by Abildgaard (...) indicates that he may have been dealing with more than one species under the same name." Whether or not Abildgaard (1790) was dealing with a complex of several species has no nomenclatural relevance, since it neither it interferes with the availability of the name $T$. corollata nor stands as an impediment for the appointment of this name as a senior synonym of A. coronatum.

Once the type species of Acanthobothrium and its current valid name is clarified, the identity of the type host may now be addressed. According to Williams (1969: 9), "A. coronatum should be regarded as a cestode of Scyliorhynus stellaris only." Williams' (1969) statement ignores that the concept of $B$. bifurcatus is correlated with Leuckart's (1819: 31-32) to T. corollata, which according to Abildgaard (1790: 63), had only been found in R. batis. The corollary of this historical event is that the type species of Acanthobothrium is associated with $R$. batis.

In an effort to more completely understand the concept of $A$. corollatum, we attempted to locate the type materials used in the original descriptions of its older synonyms. Unfortunately, all of Abildgaard's material was lost throughout the years (Buchmann, per. comm.) and our efforts to locate Leuckart's original material have also been fruitless. At this point, it seems 
that the type series of $A$. corollatum (including older synonyms) could have been lost. In this case, assigning a neotype for $A$. corollatum would not be recommended since the type material would have to be consistent with the original concept of its synonyms (ICZN Art. 74-75), which are related to parasites of $R$. batis. According to Campbell and Beveridge (2002), there are at least five nominal species of Acanthobothrium known to occur in R. batis (A. coronatum, A. icelandicum, A. parvum, A. rajaebatis, and A. septentrionale) and the original description of $T$. corollata may not suffice the requirements to identify which one is Abildgaard's concept of $T$. corollata.

We conclude that the authorship of Acanthobothrium belongs to Blanchard (1848). The type species of Acanthobothrium is Acanthobothrium coronatum Blanchard, 1848, a junior synonym of Acanthobothrium corollatum (Abildgaard, 1790) n. comb. The type host of A. corollatum and therefore Acanthobothrium is Raja batis L.

\section{Acknowledgements}

The authors acknowledge financial support from FAPESP (Proc. No. 2009/ 13561-5). We would like to thank Joanna J. Cielocha, for reading earlier versions of this manuscript. We are specially grateful to Sérgio Antonio Vanin, Silvio Shigueo Nihei, and Ubirajara Ribeiro Martins for their priceless insights on the nomenclatural problems we found during our research. We would also like to demonstrate our appreciation for the librarian services of Dione Seripiere (Museu de Zoologia da Universidade de São Paulo) and Claire Pascaud and Grégory Van Aelbrouk (Académie royale des Sciences, des Lettres et des Beaux-Arts de Belgique). This work would not be possible without the Biodiversity Heritage Library (www.biodiversitylibrary.org), from where we obtained the 19th and early 20th century publications cited herein.

\section{References}

Abildgaard, P. C. 1790. Almindelige Betragtninger over Indvolde-Orme, Bemærkninger ved Hundsteilens Bændelorm, og Beskrivelse med Figurer af nogle nye Bændelorme. Skrivter af Naturhistorie-Selskabet 1(1): 26-64.

Baer, J. B. 1948. Contributions a l'étude des cestodes de Sélaciens. I-IV, Bulletin de la Société neuchateloise des Sciences naturelles 71: 63-122.

Blanchard, C. É. 1848. Sur l'organisation des vers. Annales des Sciences Naturelles 10: 321364. URL: http: / / www. biodiversitylibrary.org/item/ 49250.

Blanchard, C. É. 1849. Sur l'organisation des vers. Annales des Sciences Naturelles 11: 106202. URL: http: / / www.biodiversitylibrary.org/item/ 48057. 
Campbell, R. A. and I. Beveridge. 2002. The genus Acanthobothrium (Cestoda: Tetraphyllidea: Onchobothriidae) parasitic in Australian elasmobranch fishes. Invertebrate Systematics 16: 237-344.

Fyler, C. A. 2011. An extremely hyperapolytic Acanthobothrium species (Cestoda: Tetraphyllidea) from the Japanese Wobbegong, Orectolobus japonicus (Elasmobranchii: Orectolobiformes) in Taiwan. Comparative Parasitology 78(1): 4-14.

Goldstein, R. J. 1967. The genus Acanthobothrium Van Beneden, 1849 (Cestoda: Tetraphyllidea). The Journal of Parasitology 53(3): 455-483.

ICZN. 1999. International Code of Zoological Nomenclature. London: International Trust for Zoological Nomenclature. xxix +306 .

Jensen, K. and J. N. Caira. 2008. A revision of Unibilocularis Southwell, 1925 (Tetraphyllidea: Onchobothriidae) with the description of four new species. Comparative Parasitology: 75(2): 157-173.

Khalil, L. F.; A. Jones, and R. A. Bray (eds.). 1994. Keys to the cestode parasites of vertebrates. Wallingford: CAB International. $751 \mathrm{pp}$.

Leuckart, F. S. 1819. Zoologische Bruchstuicke. Helmstädt. 70 pp.

Linton, E. 1925. Notes on cestode parasites of sharks and skates. Proceedings of the United States National Museum 64: 1-114.

Muquardt, C. (ed.). 1849. Bibliographie de la Belgique, p.12. Bruxelles: Librairie Allemande et Étrangère. vol. 12, no. 1. [Ref. No. 118: Van Beneden (1849) Notice sur un nouveau genre d'Helminthe cestoïde. Bulletins de L'Acaémie Royalle des Sciences, des Lettres et des Beaux-Arts de Belgique 16(2):182-193].

Neave, S. A. (ed.). 1939. Nomenclatur zoologicus: a list of the names of genera and subgenera in zoology from the tenth edition of Linnaeus 1758 to the end of 1935. Vol. I. A-C. Zoological Society of London. 957 pp.

Reyda, F. B. and J. N. Caira. 2006. Five new species of Acanthobothrium (Cestoda: Tetraphyllidea) from Himantura uarnacoides (Myliobatiformes: Dasyatidae) in Malaysian Borneo. Comparative Parasitology 73(1): 49-71.

Rudolphi, K. A. 1819. Entozoorum synopsis cui accedunt mantissa duplex et indices locupletissimi. Berolini. 811 pp.

Twohig, M. E.; J. N. Caira, and C. A. Fyler. 2008. Two new cestode species from the dwarf whipray, Himantura walga (Batoidea: Dasyatidae), from Borneo, with comments on site and mode of attachment. Journal of Parasitology 94(5): 1118-1127.

Van Beneden, P. J. 1849. Notice sur un nouveau genre d'Helminthe cestoïde. Bulletins de L'Acaémie Royalle des Sciences, des Lettres et des Beaux-Arts de Belgique 16(2): 182193. URL: http: / / www .biodiversitylibrary . org/bibliography/5550. 
Van Beneden, P. J. 1850. Recherches sur la faune littorale de Belgique. Les vers cestoides, considérés sous le rapport physiologique, embryogénique et zooclassique. Mémoires de l'Academie Royale des Sciences, des Lettres et des Beaux-Arts de Belgique 25: 1-204. URL: http://www.biodiversitylibrary.org/item/101746.

Vardo-Zalik, A. M. and R. A. Campbell. 2011. Five new species of Acanthobothrium van Beneden, 1849 (Cestoda: Tetraphyllidea) in elasmobranchs from the northwest Atlantic and Gulf of Mexico with first records from smooth-hound sharks and guitarfish. Zootaxa 2838: $41-64$.

Williams, H. H. 1969. The genus Acanthobothrium Beneden 1849 (Cestoda: Tetraphyllidea). Nytt Magazine of Zoology 17: 1-56.

Yamaguti, S. 1959. Systema helminthum II: the cestodes of vertebrates. London: Interscience Publishers Ltd. 860 pp.

Zschoche, M.; J. N. Caira, and C. A. Fyler. 2011. A new species of Acanthobothrium van Beneden, 1850 (Tetraphyllidea: Onchobothriidae) from Pastinachus atrus (Macleay) (Batoidea: Dasyatidae) in Australian waters, with a reassessment of the host associations of Acanthobothrium spp. parasitising Pastinachus spp. Systematic Parasitology 78: 109-116. 


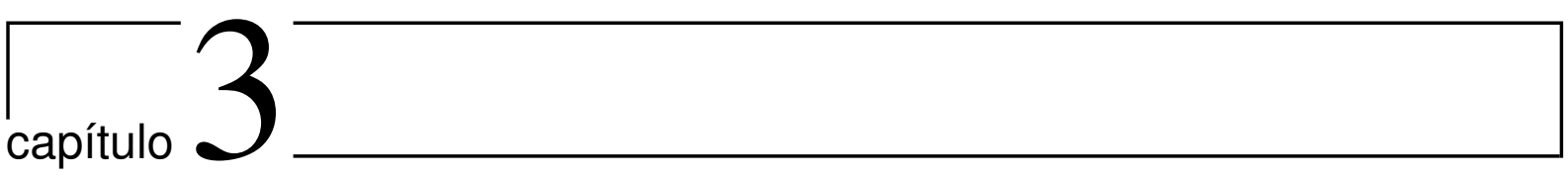

\title{
Diversification and species boundaries of Acanthobothrium
}

\author{
(Eucestoda: Tetraphyllidea: Onchobothriidae) parasites of \\ freshwater stingrays (Myliobatiformes: Potamotrygonidae)
}

\subsection{Introduction}

Acanthobothrium Blanchard, 1848 comprises an ubiquitous and specious genus of elasmobranch parasites characterized by tricolulate bothridia, each one armed with a pair of bifurcated hooks (Southwell, 1925). Since the erection of the genus, approximately 200 Acanthobothrium species have been described from elasmobranchs in all major oceans (e.g., Campbell and Beveridge, 2002; Ivanov, 2005; Reyda and Caira, 2006; Jensen and Caira, 2008; Twohig et al., 2008; Fyler, 2009; Fyler and Caira, 2006, 2010; Fyler, 2011; Zschoche et al., 2011). Few species of Acanthobothrium have also been reported from the rivers of South America since the 1970's (Rego and Dias, 1976; Mayes et al., 1978; Brooks et al., 1981a; Ivanov, 2005; Reyda, 2008). Until 2010, a total of six South American freshwater species of Acanthobothrium were recognized: Acanthobothrium terezae Rego and Dias, 1976; A. amazonensis Mayes, Brooks and Thorson, 1978; A. quinonesi Mayes, Brooks and Thorson, 1978; A. regoi Brooks, Mayes and Thorson, 1981a; A. ramiroi Ivanov, 2005; and A. peruviense Reyda, 2008. However, recent evidence suggests that the taxonomic status of these species must be reviewed (Cardoso, 2010) .

Historically, most species of Acanthobothrium have been described based on a restricted number of specimens from distant localities and host species. This practice has led researchers to describe new species based on the premises that those lineages present low morphological variation. Recently, Cardoso (2010) addressed the morphological variation within and between freshwater species of Acanthobothrium using considerable numbers of specimens collected 
from many species of potamotrygonids from all major drainages of South America. This unprecedented sampling effort unveiled a morphological variation within Acanthobothrium species, which has never been reported in the taxonomic history of the genus. According to Cardoso (2010), only five freshwater species of Acanthobothrium should be recognized as valid: A. terezae (syn. A. ramiroi), A. quinonesi (syn. A. regoi and A. peruviense), A. amazonensis, and two new species still undescribed. However, Cardoso (2010) claimed that new sources of data (e.g., molecular) would be necessary to better understand the taxonomic status of species of this genus in Neotropical freshwater systems.

The intention of this contribution is to evaluate the taxonomic status and phylogenetic position of the nominal species of Acanthobothrium in the freshwater environment. To achieve this goal, we associate morphological cohesion with phylogenetic patterns of monophyly recovered from nucleotide data of multiple loci. This is the first attempt to include all freshwater species of Acanthobothrium in a broader phylogenetic context which includes representatives of several marine species of Acanthobothrium as well as their closest relatives. In doing so, we address conflicting patterns of host specificity and morphological variability between freshwater and marine species of Acanthobothrium. We also discuss conflicting hypothesis of colonization of South American freshwater by Acanthobothrium species.

\subsection{Material and methods}

\subsubsection{TAXONOMIC REPRESENTATION OF MARINE TETRAPHYLLIDEANS}

The position of Acanthobothrium within tetraphyllidean cestodes is currently unclear. Also, the monophyly of the freshwater lineages still awaits phylogenetic testing. Thus, for the purposes of this study, sequences from 10 members of Proteocephalidea and three specimens of Acanthobothrium were obtained from GenBank (Appendix A.7, Table A.3). Other sequences from hooked tetraphyllideans, including several additional species representing marine lineages of Acanthobothrium, were kindly provided by Dr. Caroline A. Fyler (Fyler, 2009; unpublished data) (Appendix A.8, Table A.4). Our data set for marine tetraphyllideans is believed to be representative of the taxa more closely related to Acanthobothrium based on the results of a larger analysis by Caira (per. comm.) with representation of 80 percent of tetraphyllidean genera. Trees were rooted with a species of an undescribed tetraphylliden genus as they consistently grouped outside Acanthobothrium, Uncibilocularis Southwell, 1925, Potomotrygonocestus Brooks and Thorson, 1976 and Proteocephalidea in the trees generated by Caira (per. comm.). The collect of biological material and sequencing of DNA data from parasites followed the above strategies and protocols in order to expand the representativity of freshwater lineages of Acanthobothrium on Fyler's (2009) datset, thus allowing the evaluation of their reciprocal monophyly and phylogenetic position. 


\subsubsection{COLLECTION OF FRESHWATER STINGRAY SPECIMENS}

Freshwater stingrays were collected from multiple localities (see Appendix A.1, Table A.1) throughout the Amazon and La Plata River basins in South America from July of 2004 to January of 2011 (see Fig. 3.1). These localities represent most of the major river systems of South America from which potamotrygonids have been historically reported (de Carvalho and Ragno, 2011; de Carvalho et al., 2011) and/or included type localities for tetraphyllideans found in potamotrygonids (e.g., two different collections at the Salobra River in Mato Grosso do Sul State, Brazil, the River referred to as the type locality of A. terezae). Collecting, fixation, identification, and deposition of biological material from stingrays follows the procedures and guidelines of Reyda and Marques (2011).

Unidentified species were assigned either by regional common names (e.g., Potamotrygon sp. "jabuti" or "negra"). Images of each stingray specimen from which cestodes were collected are available on-line (see Marques and Domingues, 2011) and can be searched in the database using the field code for each locality that is provided in Table A.1

\subsubsection{COLLECTION OF CESTODE SPECIMENS}

The spiral intestine of 198 stingray specimens was removed, opened with a mid-ventral incision, and examined for parasites with a dissecting microscope and/or immediately immersed in $95-100 \%$ ethanol. The spiral intestines were examined in the laboratory, and cestodes were removed, and placed in vials to be stored at low temperature (approximately $-20^{\circ} \mathrm{C}$ ). Members of Acanthobothrium selected for molecular study were fragmented in 3 parts of which the scoleces and terminal portions were prepared as whole mounts to serve as vouchers (hologenophores, sensu Pleijel et al., 2008). Material prepared as whole mounts were hydrated in a graded ethanol series, stained in Delafield's hematoxylin, dehydrated in a graded ethanol series, cleared in methyl salicylate, and mounted on glass slides in Canada balsam (see Appendix A.3).

Identification of hologenophores, for freshwater species of Acanthobothrium, follows the concept of Cardoso (2010) . Each hologenophore received a field code, a molecular code (see Appendix A.4, Table A.2), and has been deposited at the Museu de Zoologia da Universidade de São Paulo (MZUSP) under the accession numbers 7349 to 7480.

\subsubsection{DNA EXTRACTION, AMPLIFICATION, AND SEQUENCING}

Fragments of cestodes were allowed to air-dry, and prepared for genomic DNA extraction, using one of the following two protocols: (1) InstaGene ${ }^{\mathrm{TM}}$ Matrix (Bio-Rad) kit; in which the reactions were performed on a total volume of $30 \mu \mathrm{l}$, and other conditions follows the manufacturer's specifications; or (2) Agencourt $^{\circledR}$ DNAdvance $^{\mathrm{TM}}$ DNA Isolation Kit optmized 


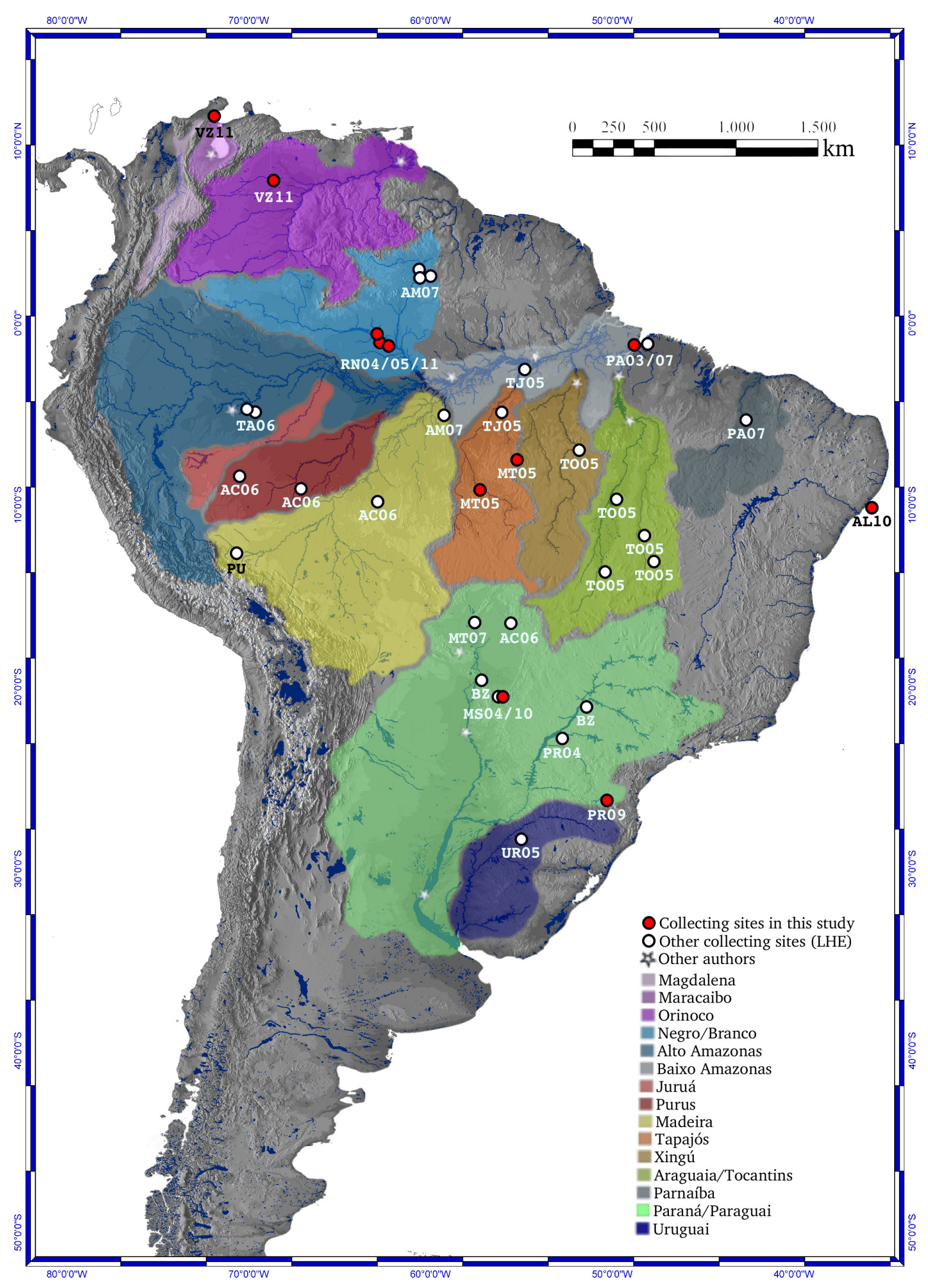

Figure 3.1: Collection sites of potamotrygonid specimens in South America. Details of field codes shown here are given in Table A.1. Figure modified from Luchetti (2011) 
for $200 \mu \mathrm{l}$ tubes and very small amounts of cestode tissue $\left(<3 \mathrm{~mm}^{3}\right)$. The concentrations of each reagent follows manufacturer's specifications. We employed the Agencourt ${ }^{\circledR}$ SPRIPlate Super Magnet Plate (see Appendix A.5) to better suit the optimized protocol for $200 \mu \mathrm{l}$ tubes.

PCR was performed on 3 genes, ITS-1, 16S and 28S rDNA. Table 3.1 shows the size of each of the sequenced genomic fragments as well as the primers employed for amplification and/or cycle sequencing.

Table 3.1: Primers used for PCR amplification and cycle sequencing.

\begin{tabular}{lll}
\hline \hline Primers used for each gene & Author(s) \\
\hline ITS1 rDNA ( 300 base pairs) & \\
ITS1A (5') & GTAACAAGGTTTCCGTAGGTG & Matejusová et al. $(2001)$ \\
ITSR3A (3') & GAGCCGAGTGATCCACC & Matejusová et al. $(2001)$ \\
Partial 16S rDNA ( 900 base pairs) & \\
Cyclo-16SF (5') & TGCCTTTTGCATCATGCT & Marques (unpublished data) \\
Cyclo-16SR (3') & AATAGATAAGAACCGACCTGG & Marques (unpublished data) \\
Partial 28S rDNA (D1-D3 region, $~ 1300$ base pairs) & \\
LSU5F (5') & TAGGTCGACCCGCTGAAYTAAGCA & Littlewood et al. (1997) \\
LSU330F (5') & CAAGTACCGTGAGGGAAAGTTG & Williams and Ozawa (2006) \\
LSU1500R (3') & GCTATCCTGAGGGAAACTTCG & Tkach et al. (1999) \\
\hline
\end{tabular}

Thermal cycles were as follows: initial denaturation for $5 \mathrm{~min}$ at $95^{\circ} \mathrm{C}$, followed by $35-40$ cycles of $30 \mathrm{secs}$ at $94^{\circ} \mathrm{C}, 40 \mathrm{secs}$ at $50-60^{\circ} \mathrm{C}$, and $1-2 \mathrm{~min}$ at $72^{\circ} \mathrm{C}$, followed by a final extension of $7 \mathrm{~min}$ at $72^{\circ} \mathrm{C}$. The specific annealing temperatures for each gene are: $55^{\circ} \mathrm{C}$ for $16 \mathrm{~S}$ rDNA, $60^{\circ} \mathrm{C}$ for $28 \mathrm{~S} \mathrm{rDNA}$, and $50^{\circ} \mathrm{C}$ for ITS $1 \mathrm{rDNA}$.

PCR reactions were performed using Techne ${ }^{\circledR}$ TC-5000 ${ }^{\mathrm{TM}}$ thermocycler. PCR products were purified using an Ampure ${ }^{\mathrm{TM}}$ kit (see Appendix A.6). Products were subsequently cycle-sequenced directly from forward, reverse, and, in some cases, internal strands, using ABI Big-Dye ${ }^{\mathrm{TM}}$ chemistry, cleaned with sephadex beads, and sequenced on an ABI 3100 Genetic Analyzer at the Centro de Sequênciamento do Departamento de Química, Institute of Chemistry, USP.

The quality of each chromatogram was checked using FinchTV version 1.3.1 (Geospiza Inc.). Contiguous sequences were assembled and edited using the package Consed/Phred Phrap (Ewing and Green, 1998; Ewing et al., 1998; Gordon et al., 1998, 2001).

\subsubsection{Phylogenetic ANALysis}

Phylogenetic reconstruction was performed with parsimony analysis of a combined data set of $16 \mathrm{~S}, 28 \mathrm{~S}$, and ITS1. The phylogenetic hypothesis was obtained from the simultaneous analysis of all data partitioned under the assumption that all available evidence maximizes explanatory power of the working hypothesis (Kluge, 1989; Nixon and Carpenter, 1996). Partial analyses 
of each gene fragment were employed to access character incongruity between individual and combined analysis.

Different partitions were created on BioEdit version 7.0.9.0 (Hall, 1999) using prealigned sequences by Muscle version 3.7 (Edgar, 2004). The phylogenetic analysis was performed in POY version 4.1.2 (Varón et al., 2010) employing the concept of dynamic homology (Wheeler, 2001a, 2001b). This concept allows characters and the characters states within those characters to be discovered simultaneously on the bases of a single optimality criterion and takes into account insertion/deletion events (i.e., INDELs) as historical evidence (Wheeler, 1996, 2002). All data partition albeit pre-aligned during partition definition were treated as unaligned and non-additive and analyzed under nine different cost ratios for gap opening, gap extention, transversions, and transitions $(2: 1: 1: 1,2: 1: 1: 2,2: 1: 2: 1,4: 2: 1: 1,4: 2: 1: 2$, $4: 2: 2: 1,8: 4: 1: 1,8: 4: 1: 2$, and $8: 4: 2: 1)$ by POY.

POY was run on the Zoology parallel computing cluster using 8 processors for partial analysis and 16 processors for combined analysis. For the sequence character optimization, two direct optimization (DO; Wheeler, 1996) algorithms were employed as part of the same search strategy as show in Figure 3.2 and specified above.

The first part of the search strategy employed Optimization Alignment (OA), generally called DO (Wheeler, 1996). Optimization Alignment optimizes hypothetical ancestral sequences based on descendant sequences. The search strategy under OA comprised tree building, branch swapping, perturbing using ratchet, and tree fusing. The first part of the strategy was set on a script using three sequential "search" commands with maximum allowed memory of two Gigabytes per processor and maximum execution time of three hours for partial analysis and nine hours for combined analysis. Each script for OA searches was run five times storing the shortest trees of each one.

On the second part of the search strategy, the shortest topologies selected during each OA searcher were subjected to a final round of branch swapping under Iterative Pass (IP). Iterative Pass optimizes hypothetical ancestral sequences based on both descendant and ancestral sequences. Therefore, IP is a three-sequence DO with iterative improvement that, although much more computationally demanding, holds the potential to find shorter solutions (Wheeler, 2003).

The selection of the working hypothesis followed the criteria of minimization of character incongruity via congruence analysis. With this purpose, the Mickevich-Farris Extra Steps Index (MFES) (MFES; Mickevich and Farris, 1981) were calculated using the length of the combined analysis to normalize the number of extra steps (see equation bellow).

$$
M F E S=\frac{\text { Length }_{\text {Combined }}-\sum \text { Length }_{\text {Partials }}}{\text { Length }_{\text {Combined }}}
$$


Capítulo 3. Diversification and species boundaries of Acanthobothrium

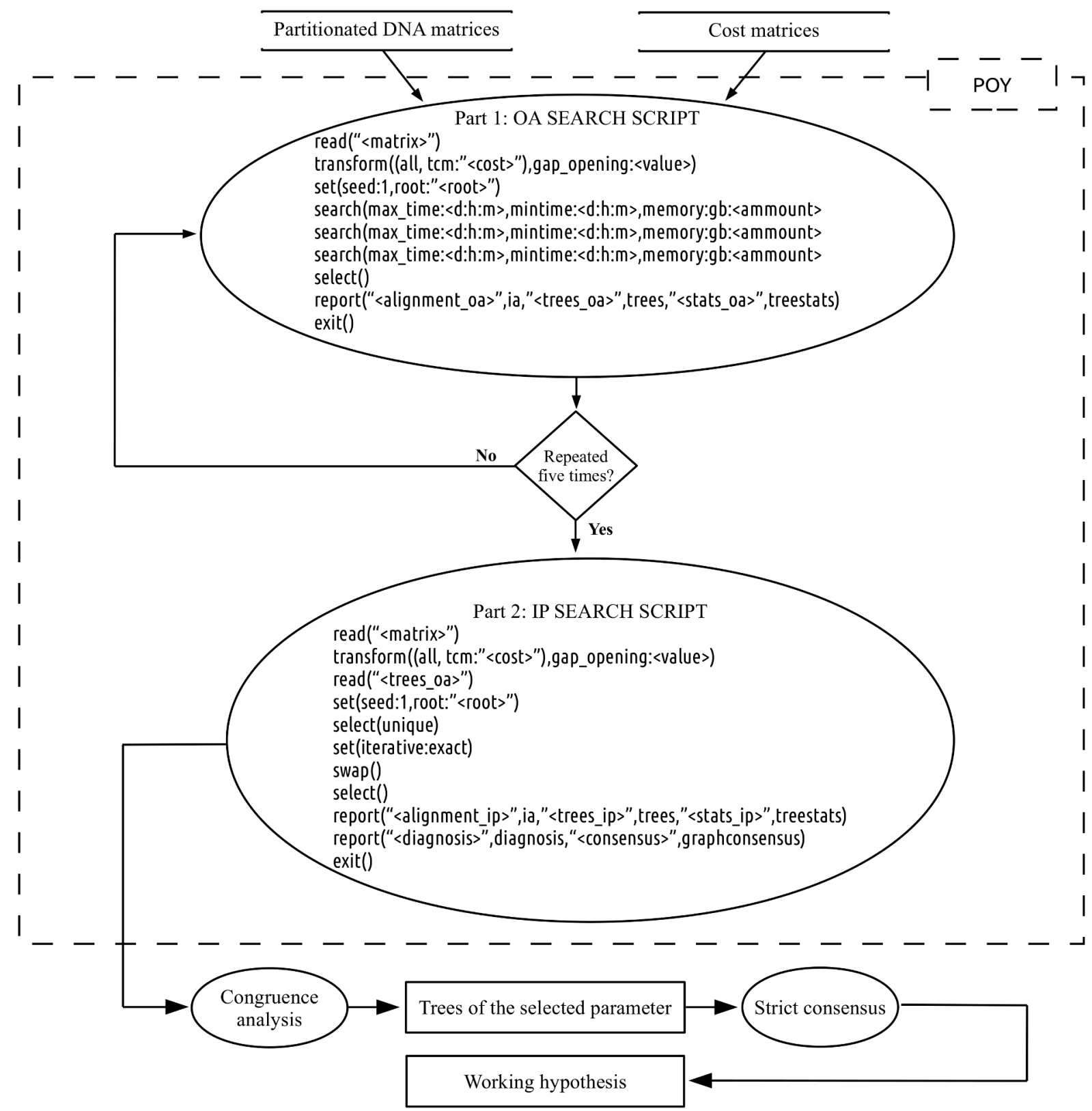

Figure 3.2: Flow chart showing the main steps of the combined DO search strategy. This strategy was repeated for the combined and partial analysis of each parameter. 
As character incongruence among data partitions increases, MFES increases. The parameter set with the lowest MFES value is selected as the working hypothesis as it means that the minimum character incongruity has been achieved (but see Dowton and Austin, 2002).

The sensitivity analysis (sensu Wheeler, 1995; Giribet, 2001) were employed using Cladescan (Sanders, 2009) to test the robustness of various clades to perturbations in the relative weighting parameters. If a clade is stable throughout the parameter space (i.e., different weighting parameters) it is considered better supported ${ }^{1}$ by the data than a clade that was recovered on fewer parameters.

The support for branches was achieved by using Branch Support values, also referred to as decay indices and Goodman-Bremer (GB) support values (Goodman et al., 1982; Bremer, 1988; 1994; see also Grant and Kluge, 2008a). Goodman-Bremer values provide measures of the objective support of a clade according to the number of extra steps required to collapse a branch in the consensus of nearly most parsimonious trees (Grant and Kluge, 2008b). GoodmanBremer values vary from zero to infinity. The higher the GB value, the more contradictory evidence would be required to be added to the matrix to erode support for a given clade. The support was calculated in the Department of Zoology - IB/USP parallel computer cluster using 24 processors. The search for suboptimal trees were executed using four different search strategies with increasing heuristic aggressiveness: (1) combined DO search with relative low aggressiveness (OA: search for 3 hours, IP: swap for 1 hour, repeat 9 times); (2 and 3) two combined DO searches with intermediate aggressiveness (OA: search for 6 or 9 hours, IP: swap for one hour); and (4) combined DO search strategy with higher aggressiveness (OA: 3 times search for 9 hours, IP: swap for one hour). Goodman-Bremer values were used to track the efficiency of each search strategy to calculate support. Goodman-Bremer calculations were made for each subset of trees found. Selected GB value for each branch represent the minimum GB values encountered, which is the GB value calculated with all four tree sets. For further details, see data flow in Figure 3.3.

Trees with an approximation of branch lengths approximately proportionals to the numbers of transformations were build parsing the diagnose (.xml) POY files by the Perl script newick 4poy5.pl (Marques, unpublished script). All tree edition was performed on Dendroscop version 3.0.10 beta (Hudson and Scornavacca, in prep.) or FigTree version 1.3.1 (Rambaut, 2006-2009) and vectorial SVG image files were further edited on Inkscape version 0.47 (Harrington et al., 2004-2011).

\footnotetext{
${ }^{1}$ Support sensu (Brower, 2006: 378): "a measure of the net amount of evidence that favors the appearance of that branch in a most-parsimonious topology”).
} 


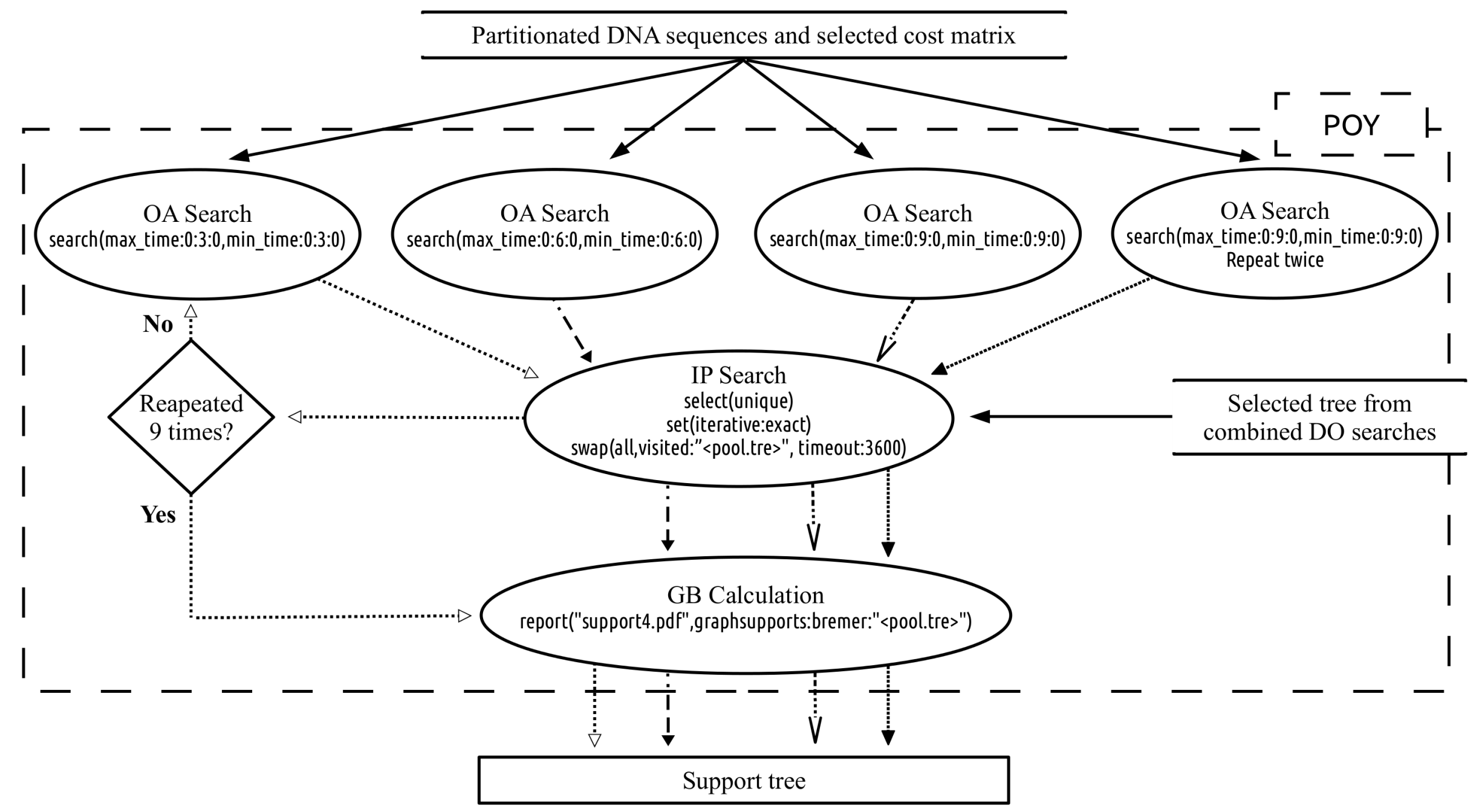

Figure 3.3: Main steps of the Goodman-Bremer calculation. 


\subsection{Results}

\subsubsection{Molecular Dataset}

The dataset generated for this analysis includes 258 new sequences from three different regions (16S, 28S, and ITS1). The complete molecular dataset employed in this study represents 10 species of Proteocephalidea and 50 species of Acanthobothrium collected from a total of 45 species and 22 genera of hosts.

\subsubsection{WORKING HYPOTHESIS}

The IP optimization was able to find shorter alignments for each of the first runs under DO. However IP was not able to find different topologies than those selected under DO. It is also interesting to note that in several cases the shortest tree under IP was considered suboptimal under DO (Table 3.2).

Table 3.2: Tree lengths from the OA combined analysis. Shaded cells indicates trees selected under IP. * Trees selected under IP that were considered sub-optimum under OA.

\begin{tabular}{cccccccccc}
\hline \hline \multicolumn{8}{c}{ Weighting parameters } \\
\hline Rounds & $\mathbf{2 : 1 : 1 : 1}$ & $\mathbf{2 : 1 : 1 : 2}$ & $\mathbf{2 : 1 : 2 : 1}$ & $\mathbf{4 : 2 : 1 : 1}$ & $\mathbf{4 : 2 : 1 : 2}$ & $\mathbf{4 : 2 : 2 : 1}$ & $\mathbf{8 : 4 : 1 : 1}$ & $\mathbf{8 : 4 : 1 : 2}$ & $\mathbf{8 : 4 : 2 : 1}$ \\
\hline $1^{\text {st }}$ & 7520 & 12328 & 11557 & 9101 & 15272 & 14611 & 11911 & 20383 & 20056 \\
$2^{\text {nd }}$ & 7520 & 12328 & 11563 & $9104^{*}$ & 15272 & 14608 & 11909 & 20388 & 20085 \\
$3^{\text {rd }}$ & 7520 & 12331 & 11554 & 9102 & 15257 & 14616 & 11910 & 20378 & 20058 \\
$4^{\text {th }}$ & 7520 & 12331 & 11558 & 9101 & $15265^{*}$ & 14616 & 11907 & 20379 & $20059^{*}$ \\
$5^{\text {th }}$ & 7520 & 12332 & 11555 & 9102 & 15263 & 14612 & 11906 & 20377 & 20058 \\
\hline
\end{tabular}

The working hypothesis selected by MFES corresponds to parameter 2:1:1:1. The results of the MFES calculations are shown in Table 3.3. Six different topologies were found with 7507 weighted steps for this parameter set. Our working hypothesis is the strict consensus of those trees, which has 166 dichotomic nodes and only five polytomies (i.e., $97 \%$ of resolved nodes). All polytomies refer to external branches and the consensus tree is considered well resolved. Figure 3.4 shows the consensus tree with collapsed nodes without the terminals. The complete consensus tree is on Appendix A.9: Fig. A.1. The first tree from parameter 2:1:1:1 was selected to generate the tree with branch length proportional to the number of transformations (Appendix A.10: Fig. A.2).

\subsubsection{MEASURE OF SUPPORT AND STABILITY}

The sensitivity analysis employed all 31 trees selected by IP for nine weighting parameters. The percentage of trees in which each clade is present is shown in Figure A.9 at the top left of each branch. Figure 3.5 shows the sensitivity plots for selected clades not present in all parameters. 
Capítulo 3. Diversification and species boundaries of Acanthobothrium

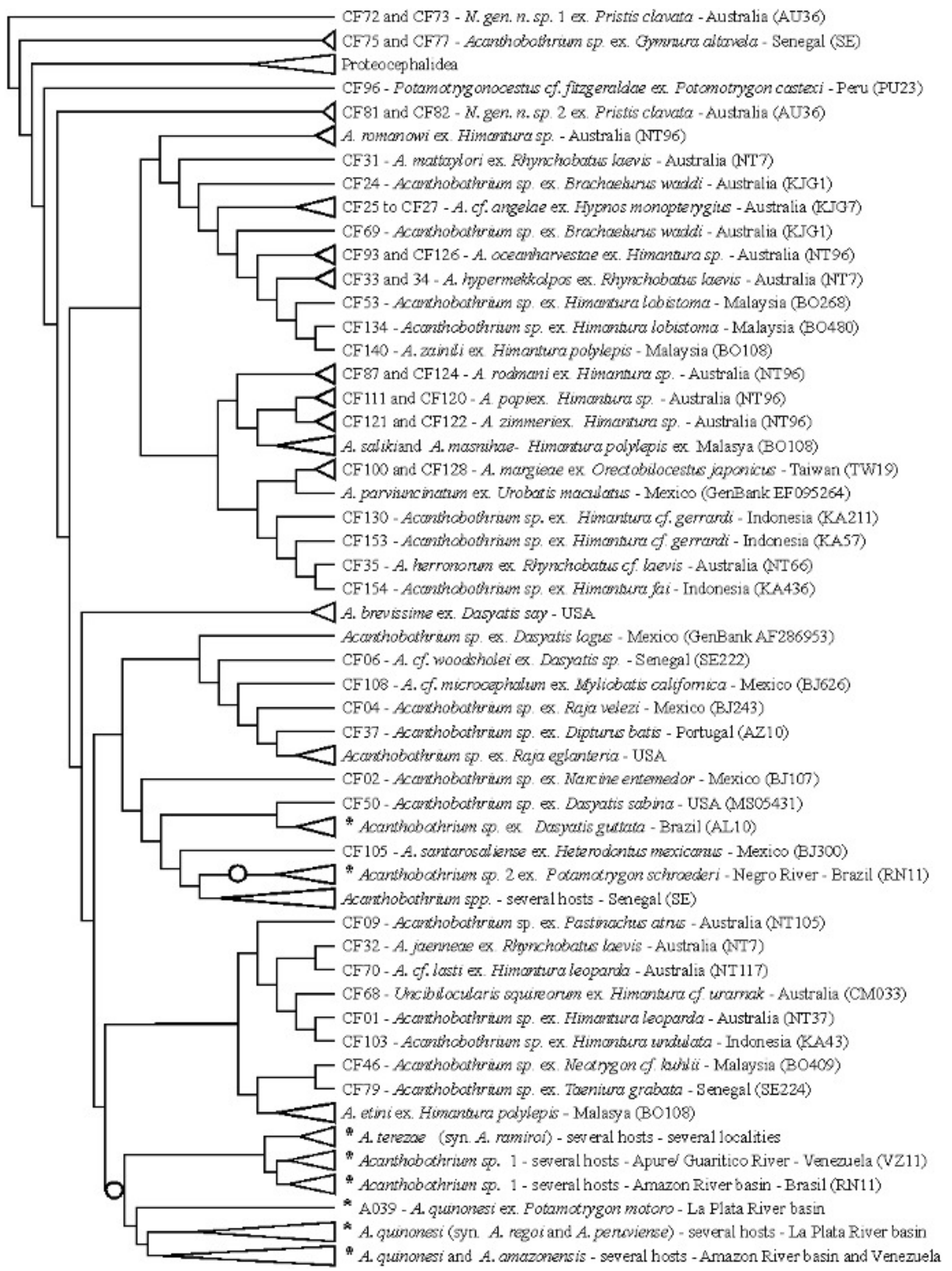

Figure 3.4: Collapsed nodes are to facilitate visualization. Open circles indicates freshwater clades. Original data are indicated by $*$. See complete consensus tree in Fig. A.1 
Table 3.3: Mickevich-Farris Extra Steps Index (MFES) calculations. The first parameter (shaded line) was selected as it minimizes character incongruity.

\begin{tabular}{cccccc}
\hline \hline \multicolumn{6}{c}{ Weighting parameters } \\
\hline Parameter & ITS1 & 28S & 16S & Total & MFES \\
\hline $2: 1: 1: 1$ & 1146 & 3043 & 3121 & 7507 & 0.026242174 \\
$2: 1: 1: 2$ & 1865 & 5326 & 4714 & 12257 & 0.028718283 \\
$2: 1: 2: 1$ & 1922 & 4363 & 4924 & 11537 & 0.028430268 \\
$4: 2: 1: 1$ & 1587 & 3674 & 3550 & 9080 & 0.029625551 \\
$4: 2: 1: 2$ & 2646 & 6504 & 5506 & 15199 & 0.035726035 \\
$4: 2: 2: 1$ & 2790 & 5586 & 5775 & 14584 & 0.029690071 \\
$8: 4: 1: 1$ & 2324 & 4823 & 4306 & 11886 & 0.036429413 \\
$8: 4: 1: 2$ & 4031 & 8530 & 6871 & 20301 & 0.042805773 \\
$8: 4: 2: 1$ & 4215 & 7821 & 7258 & 20035 & 0.036985276 \\
\hline
\end{tabular}

For GB calculations, suboptimal tree searches with increasing OA search time yielded 4318, 826, 869, and 646 trees, respectively. Goodman-Bremer values (see Fig. A.1) calculated using each of these tree sets varied in different manners between 14 and 248. The final round of branch swap under IP found cladograms as parsimonious as the selected hypothesis independently of how aggressive had been of the previous search under OA. This add support to the potential of IP to find more parsimonious cladograms (Wheeler, 2003). GB calculations using the tree set from the least aggressive OA searches provided most of the lower GB values for longer branches or branches depicting relationships between different genera. On the other hand, minimum GB values for shorter branches or branches representing inter or intra-specific relationships were only achieved using tree sets from more aggressive OA searches (see support and sensitivity measures on Appendix A.9: Fig. A.1).

\subsection{Discussion}

\subsubsection{ON THE RELATIONSHIP BETWEEN Acanthobothrium AND Uncibilocularis}

Although our primary concern in this contribution was to test the phylogenetic position of the freshwater lineages of Acanthobothrium based on molecular data, the phylogenetic pattern we recovered suggests that this genus as a whole requires revision.

The genus Acanthobothrium was not recovered as a monophyletic group either by Fyler (2009) or by any of the trees within our parameter space. The monophyly of the genus is undermined by position of two specimens (CF75 and CF77) initially identified by Fyler (2009) as "Acanthobothrium sp. 31" and one specimen (CF68) of Uncibilocularis Southwell, 1925. The species represented by terminals CF75 and CF77 have not been formally described and 

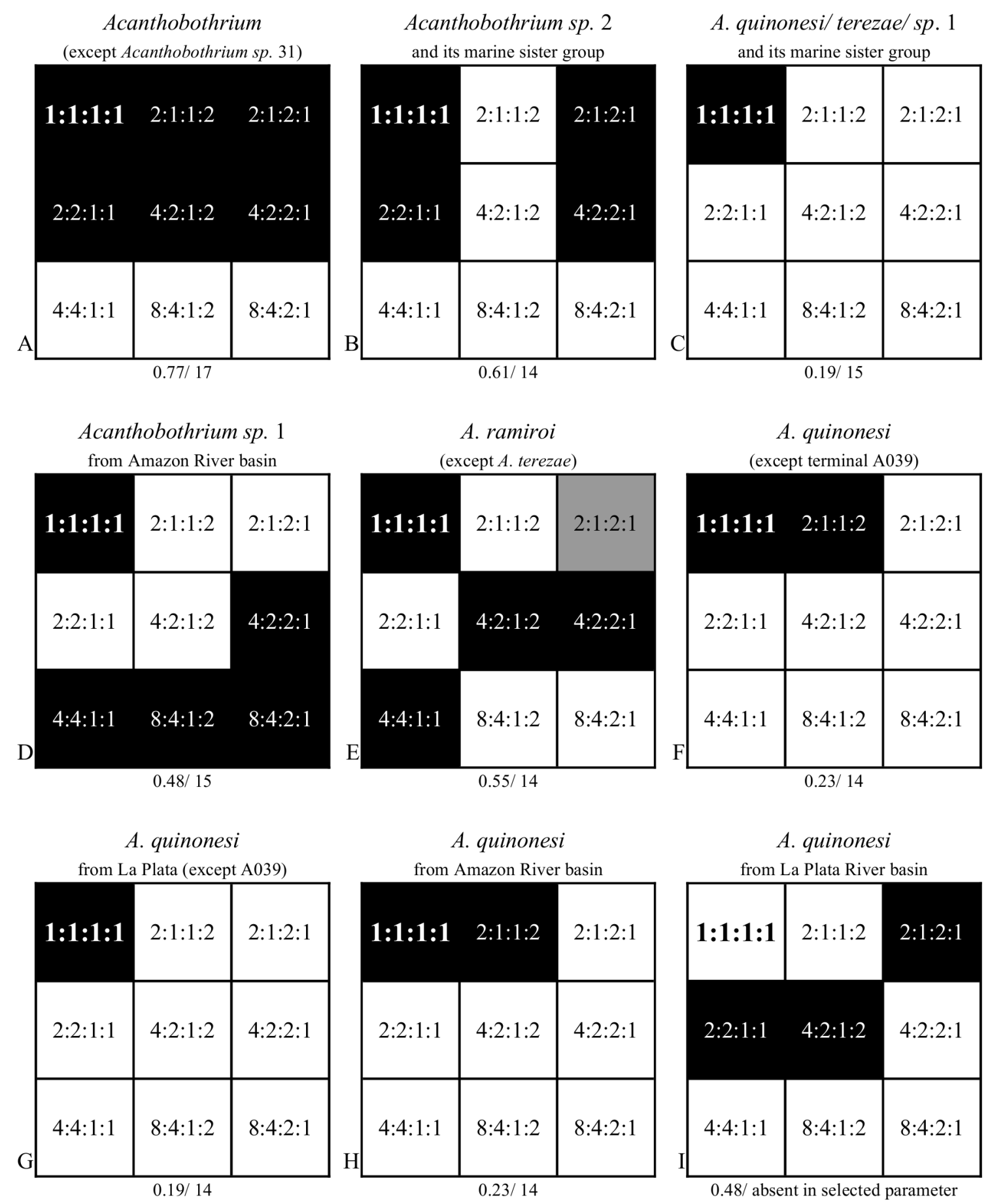

Figure 3.5: Sensitivity plot for all discussed clades which are not present in all parameters. Shades of gray that some trees within a given parameter set contained the clade. Numbers bellow each plot refer to percentage of trees with the clade and GB value, respectively. See measures of support and sensitivity in Appendix A.9: Fig. A.1. 
may show to belong to a different genus within Tetraphyllidea. However, a clade comprised by the remaining specimens of Acanthobothrium is not monophyletic unless Uncibilocularis squireorum Jensen and Caira, 2008 is included, in which case an Acanthobothrium spp. + $U$. squireorum is recovered in all the of the first six parameter sets $(2: 1: 1: 1,2: 1: 1: 2,2: 1: 2: 1$, $4: 2: 1: 1,4: 2: 1: 2$, and 4:2:2:1; see Fig. 3.5a).

The close relationship between Acanthobothrium and Uncibilocularis may be explained by the intricate taxonomic history of these genera and its relationship with Prosthecobothrium Diesing, 1863. The genus Prosthecobothrium was erected to accommodate onchobothriids that bear bipronged hooks, as Acanthobothrium, but also possessed bothridium divided into two rather than three loculi. The type species of Prosthecobothrium is Acanthobothrium dujardinii (Van Beneden, 1850). According to Southwell (1925:94), closer examination of this species revealed that "the number of loculi in A. dujardinii either vary, or one of then is so small that it cannot always be seen". Based on these observations, the author concluded that "it is obvious that the species cannot be relegated to Diesing's genus Prosthecobothrium. This genus accordingly becomes a nomen nudum". Southwell proposed Uncibilocularis as a replacement name for Prosthecobothrium, designating Uncibilocularis trygonis (Shipley and Hornell, 1906) (syn. P. trygonis) as its type species. Uncibilocularis was originally described by Southwell (1925) as an Onchobothriidae in which each bothridium is divided into two loculi by a single septum, and it is armed with either simple or "compound" (i.e., bifurcated) hooks. Since then, the concept of Uncibilocularis has been redefined to include only biloculate onchobothriids bearing a single pair of bipronged hooks per bothridium (e.g., see Euzet, 1994; Khalil et al., 1994).

Jensen and Caira (2008) provided the latest review of Uncibilocularis. These authors made 12 emendations to Euzet's (1994) description of Uncibilocularis but stated that "these generic attributes of Uncibilocularis cannot be considered as synapomorphies of the genus. Only in combination do these features allow species of Uncibilocularis to be distinguished from species of Acanthobothrium". Finally, Jensen and Caira (2008: 172) concluded that "the monophyly of these 2 genera relative to one another remains uncertain until a broad scale phylogenetic analysis can be performed to explore this particular question".

Our analysis suggests that Uncibilocularis may represent a derived lineage of Acanthobothrium which lost one loculi on its bothridium. The implication would be that Uncibilocularis should be considered junior synonym of Acanthobothrium and that the current description of this genus should be emended to include biloculated species. New molecular and morphological information for different species of Uncibilocularis are needed to test the reciprocal monophyly of these genus. 


\subsubsection{FRESHWATER Acanthobothrium AND INTRA-SPECIFIC VARIATION}

This study represents the first attempt to evaluate the reciprocal monophyly of members of Acanthobothrium parasites of potamotrygonids. In doing so, we added support to the morphological concepts of most of these species as proposed by Cardoso (2010), in agreement with the high levels of intra-specific morphologic variation observed by the author.

Our molecular data corroborated the morphological concept of Acanthobothrium sp. 1 and Acanthobothrium sp. 2 as the clades representing these species were recovered with high support and stability (see Fig. 3.4). Acanthobothrium sp. 1 has a conspicuous barb at the posterior end of each hook prong which can be used to unambiguously diagnose this species. Acanthobothrium sp. 2 can be easily sorted distinguished from other potamotrygonid Acanthobothrium species by its scolex and hook morphology (i.e., slender cephalic peduncle, canoe-shaped bothridia; and long and slender hooks with prongs approximately symmetrical). The clade attributed to Acanthobothrium sp. 1 is represented by 22 specimens from four different potamotrygonids collected in Brazil and Venezuela and it is divided into a sub-clade represented by specimens collected in Barinas-Apure basin and its sister group from the Amazon foreland basin (see sensitivity plot in Fig. 3.5d). However, morphological features related to both clades overlap and therefore do not offer evidence to divide the species. In the absence of information to the contrary, we interpret these two clades composed by members of Acanthobothrium sp. 1 as resulting from populational differences rather than a recent speciation process. All quantitative and meristic characters from both these species are highly variable and many of them overlap in some degree with other freshwater species (Cardoso, 2010:44-55)

We also recovered a clade representing the A. terezaelramiroi complex. Acanthobothrium ramiroi constitutes a separate clade from A. terezae in six parameters (Fig. $3.5 \mathrm{e}$ ) but the reciprocal monophyly of $A$. terezae was never recovered. This is in conformity with Cardoso (2010), which showed that the morphometric and meristic characters originally employed by Ivanov (2005) to distinguish between A. terezae and A. ramiroi (such as total length, scolex dimensions, size of lateral and medial hook, number of proglottids, and number of testes) are actually much more variable than Ivanov could have anticipated. The congruence between the morphological concept of $A$. terezae and the molecular data presented here adds evidence to the idea that $A$. terezae is senior synonym of $A$. ramiroi. This was proposed by Cardoso (2010) based on the larger length of the posterior loculi (165-370 $\mu \mathrm{m}, 280.96$ $\pm 53.85,16$; all measurements are presented respectively as ranges, mean, standard deviation, and number of measured specimens $)^{2}$ for A. terezae compared to all other potamotrygonid Acanthobothrium spp. Acanthobothrium terezae differs from all other Acanthobothrium

\footnotetext{
${ }^{2}$ For further information, refer to text and Tables 5-6 on Cardoso (2010) .
} 
parasites of potamotrygonidae for the bigger length of its posterior loculi. Acanthobothrium terezae differs further from Acanthobothrium sp. 1 and Acanthobothrium sp. 2 by having more proglottids (70-175 $\mu \mathrm{m}, 112 \pm 45,11)$, a wider scolex (555-12155 $\mu \mathrm{m}(958.50 \pm 206.63,10)$, and a longer scolex (590-12,055 $\mu \mathrm{m}(955.83 \pm 126.59,18)$, bothridium $(390-860,759.23 \pm 147.67$, $13)$, and anterior loculi $(185-4545 \mu \mathrm{m}, 324.44 \pm 66.84,17)$.

However, the reciprocal monophyly of A. quinonesi and A. amazonensis is not recovered in any of our parameter sets. Cardoso (2010) considered A. quinonesi a synonym of both $A$. regoi and $A$. peruviense since all characters that were used to identify each of these nominal species were based on measurements of only a few specimens or on the shape of variable morphological structures, not unique to any of them. All morphometric and merist characters used to distinguish A. quinonesi from A. amazonensis overlap, but Cardoso (2010) was able to distinguish A. amazonensis from A. quinonesi based on the shape of the cirrus sac.

The morphology of the cirrus sac has been traditionally used in the taxonomy of freshwater lineages of Acanthobothrium (e.g., Mayes et al., 1978; Reyda, 2008). However, the morphology of this structure may vary within each taxon. These observations depend on a large number of samples. Reyda (2008: 695) distinguished A. peruviensefrom A. quinonesi based on meristic characters (i.e., total length, width of the terminal proglottids, width of the bothridia, and length of the anterior and posterior bothridial loculi) and on the format of the cirrus sac of 9 specimens. Cardoso (2010), to whom 24 specimens of this species complex were available, was able to observe that the characters used by Reyda (2008) varied and overlapped, supporting the conclusion that $A$. quinonesi and A peruviense should be considered the same species. According to Cardoso (2010), the cirrus sac in A. amazonensis is piriform and straight, where as the cirrus sac of $A$. quinonesi is curved or J-shaped in the young proglottids and assumes a triangular or T-shape at maturity. However, Cardoso (2010) had only 4 specimens of A. amazonenis available, which according to the author would have immediate impact over the observed phenotypic variability observed. Our results indicate that a revision of the taxonomic status of A. quinonesi and A. amazonensis is required and that, in the absence of information to the contrary, they may be considered synonyms.

The clade comprised by haplotypes attributed to A. quinonesi is roughly divided into specimens from La Plata River basin and others from Amazon River basin and Venezuela (see Fig. A.1). However, the monophyly of the clade comprising species of A. quinonesi from La Plata River is challenged by the position of terminal A039. The terminal A039 is weakly supported as the sister group of the remaining specimens of the A. quinonesilamazonensis complex. The clade consisted of all specimens of the A. quinonesilamazonensis complex except A039 is present in only two of nine parameters (see Fig. 3.5f) and is also one of the least supported nodes in the tree (GB value of 14). Although the clade comprising members of A. quinonesi from La Plata is not present in the selected hypothesis, it was recovered 
on 3 other parameter sets (Fig. 3.5i). The clade consisting of haplotypes of A. quinonesi from La Plata (except terminal A039) is unstable (it was only recovered in the trees of the selected parameter set; see Fig. 3.5g) and also one of the clades with lowest support. The clade representing members of $A$. quinonsei from Amazon River basin is also unstable (two of nine parameter sets; Fig. 3.5h). As the nodes representing intra-specific relationships between A. quinonesi/amazonensis, the clade comprising all haplotypes from A. amazonensis and A. quinonesi has low support, but it is present in all parameter sets.

The phylogenetic information provided here corroborates the high phenotypic variation observed by Cardoso (2010) since most of the species he considered valid were recovered as monophyletic clades. This leads us to reiterate Cardoso's (2010) main contention that careful assessment of morphological variability is a prior requirement for the justification of its use to describe new species; and that the assessment of this variability is highly dependent on sample size and/or biogeographical representation. It is puzzling that the same variation in morphological characters have not yet been reported for marine species of Acanthobothrium, in particular, or tetraphyllidenas in general. The same pattern has however been reported for marine and freshwater members of Rhinebothrium Linton, 1890 (Reyda and Marques, 2011). Despite different levels of phenotypic variation, freshwater and marine tetraphyllideans further differ on their host specificity levels.

\subsubsection{CONFLICTING PATTERNS OF HOST SPECIFICITY BETWEEN MARINE AND FRESHWATER ENVIRONMENT}

Marine species of Acanthobothrium are remarkably host specific, exhibiting essentially oioxenous specificity (sensu Euzet and Combes, 1980) for their definitive hosts, i.e., each tapeworm species parasitizes a single host species (e.g., Acanthobothrium woodsholei Baer, 1948 only parasitizes Dasyatis centroura; Acanthobothrium holorhini Alexander, 1953 only parasitizes Myliobatis californicus). This is consistent with other onchobothriid genera, which are among "the most host specific parasite taxa in existence" (Caira and Jensen, 2001: 968). The same level of host specificity is not, however, seem in species of Acanthobothrium parasitizing potamotrygonids.

Each recognized freshwater lineage attributed to species of Acanthobothrium was found in at least three species of potamotrygonids, and their host list is growing. Our survey expanded the known host list of each of these lineages, except for Acanthobothrium sp. 2, which remains known to inhabit Potamotrygon orbigny, Po. schroederi (type host), and an unidentified Potamotrygon species ("negra" or "tpj2" from Tapajós river). We added Po. orbigny, Po. schroederi, and Po. yepezi to the list of know hosts of Acanthobothrium sp. 1 which already included Paratrygon aiereba (type host) and Potamotrygon sp. (“cururu"). We 
also included Po. orbigny to the host list of A. terezae, which also comprises Pa. aiereba, Po. brachyura, Po. motoro (type host), and Po. scobina. But the lowest level of host specificity in Acanthobothrium still belongs to the A. quinonesi/amazonensis species complex. Cardoso (2010) encountered specimens of A. amazonensis species in its type host (Po. motoro) and in two additional host species (Potamotrygon cf. motoro and Potamotrygon sp. "toc2"). According to the same author, A. quinonesi can be found infecting those three species of hosts plus 20 other species: Pa. aiereba, Po. brachyura, Po. falkneri, Po. henlei, Po. histrix, Po. leopoldi, Po. magdalena (type host), Po. orbignyi, Po. schroederi, Po. scobina, Potamotrygon cf. 2 motoro, Potamotrygon cf. castexi, Potamotrygon cf. orbignyi, Potamotrygon sp. ("tar1"), Potamotrygon sp., Potamotrygon sp. ("toc1"), Potamotrygon sp. (“toc3”), Potamotrygon sp. (“toc4”), Potamotrygon sp. (“jabuti”), and Potamotrygon sp. ("mar1"). In addition to that, we found mature specimens of the $A$. quinonesi/amazonensis species complex in the spiral valves of Potamotrygon sp. ("negra"), Potamotrygon sp. ("tpj1"), and Po. yepezi.

Reyda and Marques (2011) reported the same disparity regarding levels of host specificity between freshwater and marine lineages of Rhinebothrium. These authors suggested that ecological and historical factors could have played a role in defining the patterns we see presently in this system. These factors could easily be invoked to explain low specificity in Acanthobothrium and other genera of tetraphyllideans that are exclusive to the Neotropical freshwater system, such as Potamotrygonocestus Brooks and Thorson, 1976 (Luchetti et al., 2008) and Rhinebothroides Mayes, Brooks and Thorson, 1981 (Bueno, 2010). From a historical standpoint, a low degrees of host specificity could result from a combination of host switching and diversification of host lineages without the corresponding speciation in their associated parasite lineage(s) (Poulin, 2007), which may or may not be related to the age of this potamotrygonid/parasite system (for conflicting hypothesis regarding the age of this system, see Lovejoy et al., 1998; de Carvalho et al., 2004). From a ecological point of view, multiple potamotrygonid species occur sympatrically (de Carvalho et al., 2003) and many different potamotrygonid species have an overlapping diet (Shibuya et al., 2009), which may have allowed trophic exchange of cestode fauna between hosts, possibly facilitating hot switching. Nevertheless, none of these explanations can be tested until a phylogenetic hypothesis for the Potamotrygonidae is available.

One should consider that the high specificity and low morphological variation within marine species of Acanthobothrium could be an artifact of the restricted number of specimens traditionally used in species descriptions. For example, the last 11 described species of Acanthobothrium were based on the examination of 2-28 specimens of tapeworms from no more than one locality for each one (Vardo-Zalik and Campbell, 2011; Zschoche et al., 2011; Fyler, 2011; Fyler and Caira, 2010). This phenomenon remains to be demonstrated. The number 
of specimens used in descriptions of marine Acanthobothrium species should be increased in order to test this phenomenon under a taxonomic and phylogenetic framework.

\subsubsection{PHylogenetiC RELATIONSHIPS AMONG FRESHWATER Acanthobothrium}

Brooks et al. (1981b) provided the first phylogenetic analysis of freshwater species of Acanthobothrium. At the time, four species of freshwater Acanthobothrium were recognized, and hypothesized to be related as follows: (((A. quinonesi, A. regoi), A. amazonensis), A. terezae). Since then, two new species of Acanthobothrium parasitizing potamotrygonids have been described (A. ramiroi and $A$. peruviense) and two more await formal description (referred to here as Acanthobothrium sp. 1 and Acanthobothrium sp. 2; see Cardoso (2010)). To date, A. terezae is considered senior synonym of $A$. ramiroi, and A. quinonesi is considered senior synonym of $A$. regoi and A. peruviense (Cardoso, 2010). Thus, our results provide the first comprehensive phylogenetic analysis of freshwater lineages of Acanthobothrium encompassing the current taxonomic diversity of this genus.

Freshwater lineages of Acanthobothrium are not monophyletic. Topologies from all parameter sets support this assertion. The first freshwater clade is comprised by haplotypes of Acanthobothrium sp. 2, which is more closely related to marine species of Acanthobothrium from Senegal than any other freshwater lineage (Fig. 3.5b). Acanthobothrium sp. 2 share many morphological similarities with these Senegal species, which are absent in the remaining freshwater lineages of its genus: medial and lateral hooks similar in size, straight cirrus sac, and total number of testes equal to or less than 80. At the same time, Acanthobothrium sp. 2 can be distinguished from its sister group by presenting hooks with axial prongs longer than abaxial prongs, apolysis apolytic, symmetric ovary, and total length greater than $15 \mathrm{~mm}$.

The remaining species of Acanthobothrium from the South American freshwater system $(A$. quinonesi, A. amazonensis, A. terezae, and Acanthobothrium sp. 1) comprise a monophyletic group (this clade is present on trees from the nine parameters, but with low support). Cardoso (2010) distinguished the species complex of A. terezae/ramiroi from the remaining freshwater lineages by the presence of more conspicuous musculature extending from the scolex to the strobila, larger number of testes, and larger hooks. The conspicuous morphological differences that immediately distinguishes A. terezae/ramiroi from the remaining freshwater species of Acanthobothrium and the resemblance of these species could be naively be interpreted as an indication that Acanthobothrium sp. 1 is more closely related to the species complex of $A$. quinonesilamazonensis than to A. terezae/ramiroi. Our results contradict this idea, suggesting that A. terezaelramiroi and Acanthobothrium sp. 1 are sister group of the clade comprised by A. amazonanesis and A. quinonesi. Although this second clade of freshwater Acanthobothrium is not sensitive to alignment parameters, its relationship with its marine sister group is. Despite 
the observation that the clade is not one of the least supported clades ( $G B=15)$, it was only recovered for the selected parameter set (Fig. 3.5i).

Freshwater species of Acanthobothrium have low specificity of the parasites and widespread geographical distribution, which overcomes the distribution of many of their hosts. In this context, our data could further be interpreted as a suggestion that the evolutionary history of species of Acanthobothrium in Neotropical river systems could be more related to palegeographical history of the Neotropical region than to the diversification patterns of their hosts. This hypothesis is supported by the distribution and population relationships between freshwater lineages. For example, Acanthobothrium sp. 1 is divided into two clades representing the Orinoco and the Amazon River basins, which could be interpreted as a result of the separation of the Llanos basin from the Amazon system by the Vaupes-Guaviare region around 10.5 Ma followed by episodic connections between those drainages via episodic connections similar to the current Casiquiare Canal or megafans in the foreland basins (Wilkinson et al., 2010; Lima and Ribeiro, 2011). Acanthobothrium quinonesi haplotypes collected in the Amazon River basin are more related to the fauna in the Orinoco than to the La Plata basin, resembling patterns observed in biogeographical analysis of several fish taxa in tropical South America (Albert and Carvalho, 2011) and the observation of semipermeable barriers dividing these drainages (Albert et al., 2004). Wide distributions such as these span the divides of one or more basins and thus may provide evidence of historical relationships among foreland basins (see Lima and Ribeiro, 2011), or simply as evidence of dispersal routes (Hubert and Renno, 2006; Domingues and Marques, 2010). Thus, expanding the data on freshwater lineages of Acanthobothrium may thus add valuable insight into the diversification of the freshwater Acanthobothrium fauna in South American river systems. Unfortunately, our current data does not allow further inference into the history of Acanthobothrium diversification after the colonization of South American freshwater. Nevertheless, it surely allows us to position freshwater Acanthobothrium linages within a broader concept, supporting the hypothesis that these lineages do not share an exclusive common ancestor, which ushers us to debate the implications about how Acanthobothrium colonized Neotropical river systems.

\subsubsection{ON THE POLYPHYLY OF FRESHWATER Acanthobothrium LINEAGES AND ITS IMPLICATIONS}

Brooks et al. (1981b) suggested that the non/monophyly of potamotrygonid parasites, such as freshwater Acanthobothrium lineages, should indicate the non/monophyly of their hosts. Although this information may provide some insight about the evolutionary history of their hosts, Lovejoy (1997) pointed out that the non/monophyly of the parasites is not sufficient to support or reject host monophyly unless supporting evidence is provided (e.g., degree of 
specificity, potential frequency of host switching, sampling error probability). Lovejoy (1997) discussed why the monophyly of the parasites is not by itself evidence of the monophyly of their hosts and provided an illustrative example in his Figure 1. We modified this illustration to show two distinct scenarios in which a polyphyletic group of freshwater Acanthobothrium linages could be formed (Fig. 3.6).

To say that a non-monophyletic group of freshwater Acanthobothrium indicate the para/polyphyly of the potamotrygonids would require evidence that each host taxon holds only one parasite taxon or a monophyletic assemblage at any taxonomic level. In this case, the para/polyphyly of freshwater Acanthobothrium would only be possible via multiple invasions of South American freshwater by separated host taxa (Fig. 3.6a). This hypothesis is unlikely given the evidence (including shared morphological structures, such absence of fossa or foramen in the scapular process and presence of an extended pelvic process, which are not ecologically correlated with the freshwater environment) that support the monophyly of Potamotrygonidae (Lovejoy, 1996; de Carvalho et al., 2004). Given the monophyly of Potamotrygonidae, it is likely that two or more independent parasite lineages have invaded freshwater via the common ancestor of the freshwater stingrays. It is common for more than one marine species of Acanthobothrium to show specificity toward the same host species. In fact, it is not uncommon for two to four different species of Acanthobothrium to be found parasitizing a single host species (e.g., see Alexander, 1953; Marques et al., 1997; Caira and Burge, 2001; Ghoshroy and Caira, 2001; Fyler and Caira, 2006; Reyda and Caira, 2006). Recently, Fyler et al. (2009) reported five new species of Acanthobothrium from a single specimen of Himantura $s p$. Furthermore, synhospitalic congeners often represent multiple independent lineages (Fyler, 2009). Therefore, the monophyly of Potamotrygonidae as well as the observations of multiple independent lineages of Acanthobothrium in the same host specimen add support to the hypothesis that at least two separate lineages of Acanthobothrium could have invaded the South American freshwater via the exclusive common ancestor of the potamotrygonids, as exemplified in Figure 3.6b. The colonization of the Neotropical freshwater system by members of Acanthobothrium was followed by extensive diversification of this genus, and the resulting lineages are now well-established components of South American river systems.

\section{Acknowledgements}

This work was made possible thanks to the financial support from FAPESP (Proc. Nos. 03/01816-2, 05/01299-3, 08/09436-8, and 2009/13561-5). The authors acknowledge the partnertship with Dr. Janine Caira's lab at UCONN. We thank Drs. Taran Grant and Ward Wheeler for their generous assistance with a variety of methodological doubts. We are thankful to Joanna J. Cielocha for reading earlier versions of this manuscript. We would also like to 

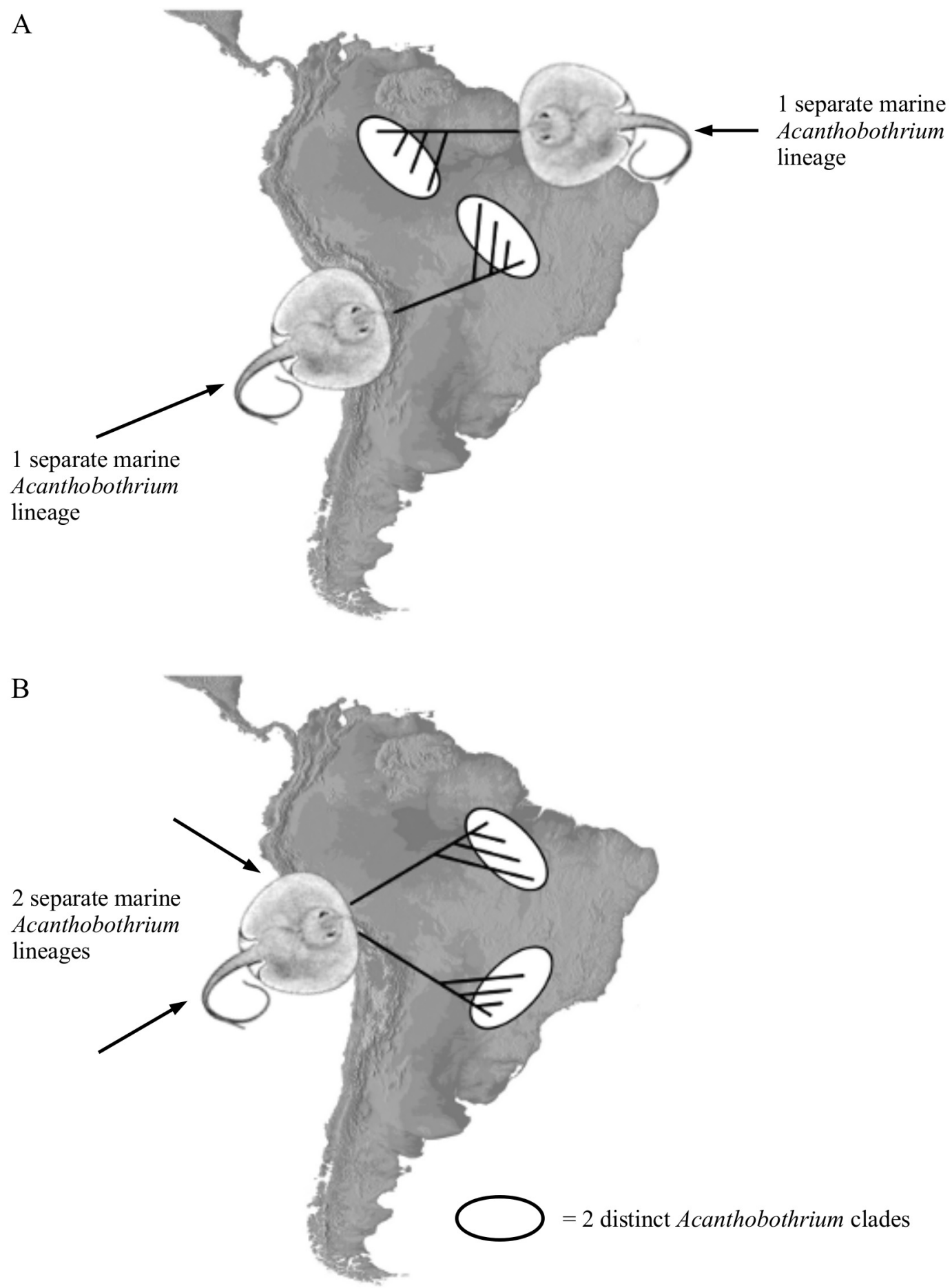

Figure 3.6: Representation of the Acanthobothrium invasion of South American freshwater. A polyphyletic group of freshwater Acanthobothrium lineages result in both scenarios, exemplifying that polyphyletic parasite clades do not necessarily indicate host polyphyly. (a) Invasion by two stingray host lineages, each infected with a separate Acanthobothrium lineage. (b) Invasion by single stingray host lineage infected with two separate Acanthobothrium lineages. Modified from Lovejoy (1997: Fig.1). 
thank Dr. Caroline A. Fyler, who gently provided the molecular dataset of marine lineages of Acanthobothrium from her $\mathrm{PhD}$ thesis.

\section{References}

Albert, J. S. and T. P. Carvalho. 2011. Neogene assembly of modern faunas. In: Historical Biogeography of Neotropical Freshwater Fishes. Albert, J. S. and R. E. Reis (eds.). Berkeley: University of California Press, pp. 119-136.

Albert, J. S.; W. G. R. Crampton; D. H. Thorsen, and N. R. Lovejoy. 2004. Phylogenetic systematics and historical biogeography of the Neotropical electric fish Gymnotus (Teleostei: Gymnotidae). Systematics and Biodiversity 2: 375-417.

Alexander, C. G. 1953. Five new species of Acanthobothrium (Cestoda: Tetraphyllidea) from southern California rays. Journal of Parasitology 39: 481-486.

Baer, J. B. 1948. Contributions a l'étude des cestodes de Sélaciens. I-IV, Bulletin de la Société neuchateloise des Sciences naturelles 71: 63-122.

Bremer, K. 1988. The limits of amino acid sequence data in angiosperm phylogenetic reconstruction. Evolution 42: 795-803.

Bremer, K. 1994. Branch support and tree stability. Cladistics 1994(10): 295-304.

Brooks, D. R. and T. B. Thorson. 1976. Two tetraphyllidean cestodes from the freshwater stingray Potamotrygon magdalenae Dumeril 1852 (Chondrichthyes: Potamotrygonidae) from Colombia. Journal of Parasitology 62: 943-947.

Brooks, D. R.; M. A. Mayes, and T. B. Thorson. 1981a. Systematic review of cestodes infecting freshwater stingrays (Chondricthyes: Potamotrygonidae) including four new species from Venezuela. Proceedings of the Helminthological Society of Washington 48(1): 43-64.

Brooks, D. R.; T. B. Thorson, and M. A. Mayes. 1981b. Freshwater stingrays (Potamotrygonidae) and their helminth parasites: testing hipotesis of evolution and coevolution. In: Advances in cladistics. Funk, V. A. and D. R. Brooks (eds.). New York: New York Botanical Garden, pp. 145-175.

Brower, A. V. Z. 2006. The how and why of branch support and partitioned branch support, with a new index to assess partition incongruence. Cladistics 22: 378-386.

Bueno, V. M. 2010. Delimitação de especies em Rhinebothroides Mayes, Brooks Thorson, 1981 (Cestoda: Tetraphyllidea) com ênfase no complexo Rhinebothroides freitasi (Rego, 1979). MA thesis. São Paulo: Universidade de São Paulo. 121 pp.

Caira, J. N. and A. Burge. 2001. Three new species of Acanthobothrium (Cestoda: Tetraphyllidea) from the ocellated electric ray, Diplobatis ommata, in the Gulf of California, México. Comparative Parasitology 68: 52-65. 
Caira, J. N. and K. Jensen. 2001. An investigation of the co-evolutionary relationships between onchobothriid tapeworms and their elasmobranch hosts. International Journal of Parasitology 31: 960-975.

Campbell, R. A. and I. Beveridge. 2002. The genus Acanthobothrium (Cestoda: Tetraphyllidea: Onchobothriidae) parasitic in Australian elasmobranch fishes. Invertebrate Systematics 16: 237-344.

Cardoso Jr., M. 2010. Taxonomia das linhagens de Acanthobothrium van Beneden, 1850 (Eucestoda: Tetraphyllidea) parasitas de Potamotrygonidae (Chondrichthyes: Myliobatiformes). MA thesis. São Paulo: Universidade de São Paulo. 69 pp.

de Carvalho, M. R. and M. P. Ragno. 2011. An unusual, dwarf new species of Neotropical freshwater stingray, Plesiotrygon nana sp. nov., from the upper and mid Amazon river basin: the second species of Plesiotrygon (Chondrichthyes: Potamotrygonidae). Papéis Avulsos de Zoologia 51(7): 101-138.

de Carvalho, M. R.; N. R. Lovejoy, and R. S. Rosa. 2003. Family Potamotrygonidae (river stingrays). In: Checklist of the freshwater fishes of South and Central America. Reis, R. E.; S. O. Kullander, and C. J. Ferraris (eds.). EDIPUCRS, pp. 22-28.

de Carvalho, M. R.; J. G. Maisey, and L. Grande. 2004. Freshwater stingrays of the Green River formation of Wyoming (early Eocene), with the description of a new genus and species and an analysis of its phylogenetic relationships (Chondrichthyes: Myliobatiformes). Bulletin of the American Museum of Natural History 284: 1-136.

de Carvalho, M. R.; M. H. S. Perez, and N. R. Lovejoy. 2011. Potamotrygon tigrina, a new species of freshwater stingray from the upper Amazon basin, closely related to Potamotrygon schroederi Fernandez-Yépez, 1958 (Chondrichthyes: Potamotrygonidae). Zootaxa 2827: 1-30.

Domingues, M. V. and F. P. L. Marques. 2010. Phylogeny and taxonomy of Potamotrygonocotyle Mayes, Brooks \& Thorson, 1981 (Monogenoidea: Monocotylidae) with a description of four new species. Journal of Helminthology 85(4): 353-380. DOI: $10.1017 /$ S0022149810000684.

Dowton, M. and A. D. Austin. 2002. Increased congruence does not necessarily indicate increased phylogenetic accuracy: the behavior of the incongruence length difference test in mixed-model analyses. Systematic Biology 51(1): 19-31.

Edgar, R. C. 2004. MUSCLE: a multiple sequence alignment method with reduced time and space complexity. BMC Bioinformatics 5(1): 113. DOI: 10.1186/1471-2105-5-113.

Euzet, L. 1994. Order Tetraphyllidea Carus, 1863, pp. 149-194. In: Keys to the cestode parasites of vertebrates. Khalil, L. F.; A. Jones, and R. A. Bray (eds.). Wallingford: CAB International. Chap. 8, p. 751. 
Euzet, L. and C. Combes. 1980. Les problemes de l'espèce chez les animaux parasites. Bulletin de la Societé Zoologique de France 3: 239-285.

Ewing, B. and P. Green. 1998. Base-calling of automated sequencer traces using Phred II. Error probabilities. Genome Research 8: 186-194.

Ewing, B.; L. Hillier; M. C. Wendl, and P. Green. 1998. Base-calling of automated sequencer traces using Phred I. Accuracy assessment. Genome Research 8: 175-185.

Fyler, C. A. 2009. Systematics, biogeography and character evolution in the tapeworm genus Acanthobothrium van Beneden, 1850. PhD thesis. Storrs: University of Connecticut. 168 pp.

Fyler, C. A. 2011. An extremely hyperapolytic Acanthobothrium species (Cestoda: Tetraphyllidea) from the Japanese Wobbegong, Orectolobus japonicus (Elasmobranchii: Orectolobiformes) in Taiwan. Comparative Parasitology 78(1): 4-14.

Fyler, C. A. and J. N. Caira. 2006. Five new species of Acanthobothrium (Tetraphyllidea: Onchobothriidae) from the freshwater stingray Himantura chaophraya (Batoidea: Dasyatidae) in Malaysian Borneo. Journal of Parasitology 92(1): 105-125.

Fyler, C. A. and J. N. Caira. 2010. Phylogenetic status of four new species of Acanthobothrium (Cestoda : Tetraphyllidea) parasitic on the wedgefish Rhynchobatus laevis (Elasmobranchii : Rhynchobatidae): implications for interpreting host associations. Invertebrate Systematics 24: 419-433.

Fyler, C. A.; J. N. Caira, and K. Jensen. 2009. Five new especies of Acanthobothrium (Cestoda: Tetraphyllidea) from an unusual species of Himantura (Rajiformes: Dasyatidae) from northern Australia. Folia Parasitologica 56(2): 107-128.

Ghoshroy, S. and J. N. Caira. 2001. Four new species of Acanthobothrium (Cestoda: Tetraphyllidea) from the whiptail stingray Dasyatis brevis in the Gulf of California, Mexico. The Journal of Parasitology 87(2): 354-372.

Giribet, G. 2001. Exploring the behavior of POY, a program for direct optimization of molecular data. Cladistics 17: 60-70.

Goodman, M.; C. B. Olson; J. E. Beeber, and J. Czelusniak. 1982. New perspectives in the molecular biological analysis of mammalian phylogeny. Acta Zoologica Fennica 169: 1935 .

Gordon, D.; C. Abajian, and P. Green. 1998. Consed: a graphical tool for sequence finishing. Genome Research 8: 195-202.

Gordon, D.; C. Desmarais, and P. Green. 2001. Automated finishing with autofinish. Gemome Research 11: 614-625.

Grant, T. and A. G. Kluge. 2008a. Credit where credit is due: The Goodman-Bremer support metric. Molecular Phylogenetics and Evolution 49: 405-406.

Grant, T. and A. G. Kluge. 2008b. Clade support measures and their adequacy. Cladistics 24: 1051-1064. 
Hall, T. A. 1999. BioEdit: a user-friendly biological sequence alignment editor and analysis program for Windows 95/98/NT. Nucleic Acid Symposium 41: 95-98.

Harrington, B. et al. 2004-2011. Inkscape. Software. URL: http: / / www . ink s cape . org.

Hubert, N. and J. F. Renno. 2006. Historical biogeography of South American freshwater fishes. Journal of Biogeography 33: 1414-1436.

Hudson, D. H. and C. Scornavacca. In prep. Dendorscope 3: an iterative viewer for rooted phylogenetic trees and networks. Software. URL: http://wWw. dendroscope. org.

Ivanov, V. A. 2005. A new species of Acanthobothrium (Cestoda: Tetraphyllidea: Onchobotriidae) from the ocellate river stigray, Potamotrygon motoro (Chondrichthyes: Potamotrygonidae), in Argentina. Journal of Parasitology 91: 390-396.

Jensen, K. and J. N. Caira. 2008. A revision of Unibilocularis Southwell, 1925 (Tetraphyllidea: Onchobothriidae) with the description of four new species. Comparative Parasitology: 75(2): 157-173.

Khalil, L. F.; A. Jones, and R. A. Bray (eds.). 1994. Keys to the cestode parasites of vertebrates. Wallingford: CAB International. $751 \mathrm{pp}$.

Kluge, A. G. 1989. A concern for evidence and a phylogenetic hypothesis of relationships among Epicrates (Boidae, Serpentes). Systematic Zoology 38: 7-25.

Lima, F. C. T. and A. C. Ribeiro. 2011. Continental scale tectonic controls of Biogeography and Ecology, pp. 145-164. In: Historical Biogeography of Neotropical Freshwater Fishes. Albert, J. S. and R. E. Reis (eds.). Berkeley: University of California Press. Chap. 9.

Linton, E. 1890. Notes on Entozoa of marine fishes of New England, with descriptions of several new species. Part II. Report of the United States Commissioner of Fisheries (1887), Washington D. C. 15: 718-899.

Littlewood, D. T. J.; K. Rohde, and K. A. Clough. 1997. Parasite speciation within or between host species? - Phylogenetic evidence from site-specific polystome monogeneans. International Journal for Parasitology 27(11): 1289-1297.

Lovejoy, N. R. 1996. Systematic of myliobatoid elasmobranchs: whith emphasis on phylogeny and historical biogeography of Neotropical freshwater stingrays (Potamotrigonidae: Rajiformes). Zoological Journal of the Linnean Society 117: 207-257.

Lovejoy, N. R. 1997. Stingrays, parasites, and neotropical biogeography: a closer look at Brooks et al.'s hypothesis concerning the origins of neotropical freshwater rays (Potamotrygonidae). Systematic Biology 46: 218-230.

Lovejoy, N. R.; E. Bermingham, and A. P. Martin. 1998. Marine incursion into South America. Nature 396: 421-422.

Luchetti, N. M. 2011. Revisão taxonômica do gênero Potamotrygonocestus Brooks \& Thorson, 1976 (Eucestoda: Tetraphyllidea). MA thesis. São Paulo: Universidade de São Paulo. $105 \mathrm{pp}$. 
Luchetti, N. M.; F. P. L. Marques, and P. Charvet-Almeida. 2008. A new species of Potamotrygonocestus Brooks and Thorson, 1976 (Eucestoda: Tetraphyllidea) from Plesiotrygon iwamae Rosa, Castello and Thorson, 1987 (Myliobatoidea: Potamotrygonidae) and redescription of Potamotrygonocestus chaoi Marques, Brooks, and Araujo, 2003. Systematic Parasitology 70: 131-145.

Marques, F. P. L. and M. V. Domingues. 2011. The collection database of the Laboratório de Helmintologia Evolutiva. website. Acess date: 2012 April 10. URL: http : / / www . ib . usp.br/hpc/hpc_search.php.

Marques, F. P. L.; D. R. Brooks, and R. Barriga. 1997. Six species of Acanthobothrium (Eucestoda: Tetraphyllidea) in stingrays (Chondrichthyes: Rajiformes: Myliobatoidei) from Ecuador. Journal of Parasitology 83: 475-484.

Matejusová, I.; M. Gelnar; A. J. A. McBeath; C. M. Collins, and C. O. Cunningham. 2001. Molecular markers for gyrodactylids (Gyrodactylidae: Monogenea) from five fish families (Teleostei). International Journal for Parasitology 31(7): 738-745.

Mayes, M. A.; D. R. Brooks, and T. B. Thorson. 1978. Two new species of Acanthobothrium van Beneden 1849 (Cestoda; Tetraphyllidea) from freshwater stingrays in South America. Journal of Parasitology 64(5): 838-841.

Mayes, M. A.; D. R. Brooks, and T. B. Thorson. 1981. Two new tetraphyllidean cestodes from Potamotrygon circularis Garman (Chondrichthyes: Potamotrygonidae) in the Itacuaí River, Brazil. Proceedings of the Helmintological Society of Washington 48: 38-42.

Mickevich, M. F. and J. S. Farris. 1981. The implications of congruence in Menidia. Systematic Zoology 30: 351-370.

Nixon, K. C. and G. H. Carpenter. 1996. On simultaneous analysis. Cladistics 12: 221-241.

Pleijel, F.; U. Jondelius; E. Norlinder; A. Nygren; B. Oxelman; C Schander; P. Sundberg, and M. Thollesson. 2008. Phylogenies without roots? A plea for the use of vouchers in molecular phylogenetic studies. Molecular Phylogenetics Evolution 48: 369-371.

Poulin, R. 2007. Evolutionary Ecology of Parasites. New Jersey: Princeton University Press. $332 \mathrm{pp}$.

Rambaut, A. 2006-2009. FigTree: tree figure drawing tool. URL: http://tree. bio.ed. ac.uk/software/figtree.

Rego, A. A. and A. P. L. Dias. 1976. Etudos de cestoides de peixes do Brasil, 3a nota: Cestoides de raias fluviais Paratrygonidae. Revista Brasileira de Biologia 36: 941-956.

Reyda, F. B. 2008. Intestinal helminths of freswater stingrays in southeastern Peru, and a new genus and two new species of cestode. Journal of Parasitology 94(3): 684-699.

Reyda, F. B. and J. N. Caira. 2006. Five new species of Acanthobothrium (Cestoda: Tetraphyllidea) from Himantura uarnacoides (Myliobatiformes: Dasyatidae) in Malaysian Borneo. Comparative Parasitology 73(1): 49-71. 
Reyda, F. B. and F. P. L. Marques. 2011. Diversification and species boundaries of Rhinebothrium (Cestoda; Rhinebothriidea) in South American freshwater stingrays (Batoidea; Potamotrygonidae). PLoS ONE 6(8): e22604. DOI: 10 . 1371 / journal. pone.0022604.

Sanders, J. G. 2009. Program note: Cladescan, a program for automated phylogenetic sensitivity analysis. Cladistics 26: 114-116.

Shibuya, A.; M. L. G. Araujo, and J. A. S. Zuanon. 2009. Analysis of stomach contents of freshwater stingrays (Elasmobranchii: Potamotrygonidae) from the middle Negro River, Amazonas, Brazil. Pan-American Journal of Aquatic Sciences 4: 466-475.

Shipley, A. E. and J. Hornell. 1906. Report on the cestode and nematode parasites from the marine fishes of Ceylon. Report to the Government of Ceylon on the Pearl Oyster Fisheries of the Gulf of Manaar (Herdman) Part 5-5: 43-96.

Southwell, T. 1925. A monograph on the Tetraphyllidea with notes on related cestodes. Memoirs of the Liverpool School of Tropical Medicine (New Series) 2: 1-368.

Tkach, V.; B. Grabda-Kazubska; J. Pawlowski, and Z. Swiderski. 1999. Molecular and morphological evidence for close phylogenetic affinities of the genera Macrodera, Leptophallus, Metaleptophallus and Paralepoderma (Digenea, Plagiorchiata). Acta Parasitologica 44(3): 170-179.

Twohig, M. E.; J. N. Caira, and C. A. Fyler. 2008. Two new cestode species from the dwarf whipray, Himantura walga (Batoidea: Dasyatidae), from Borneo, with comments on site and mode of attachment. Journal of Parasitology 94(5): 1118-1127.

Vardo-Zalik, A. M. and R. A. Campbell. 2011. Five new species of Acanthobothrium van Beneden, 1849 (Cestoda: Tetraphyllidea) in elasmobranchs from the northwest Atlantic and Gulf of Mexico with first records from smooth-hound sharks and guitarfish. Zootaxa 2838: $41-64$.

Varón, A.; L. S. Vinh, and W. C. Wheeler. 2010. POY version 4: phylogenetic analysis using dynamic homologies. Cladistics 26: 72-85.

Wheeler, W. C. 1995. Sequence alignment parameter sensivity and molecular data. Systematic Biology 44: 321-331.

Wheeler, W. C. 1996. Optimization Alignment: the end of multiple sequence alignment in phylogenetics? Cladistics 12: 1-9.

Wheeler, W. C. 2001a. Homology and the optimization of DNA sequence data. Cladistics 17: 3-11.

Wheeler, W. C. 2001b. Homology and DNA sequence data. In: The Character Concept in Evolutionary Biology. Wagner, G. P. (ed.). New York: Academic Press, pp. 303-318. 
Wheeler, W. C. 2002. Optimization alignment: down, up, error, and improvements, p. 55-69. In: Techniques in Molecular Systematics and Evolution. DeSalle, R; G. Giribet, and W. C. Wheeler (eds.). Basel: Birkhäuser Verlag. Chap. 3.

Wheeler, W. C. 2003. Implied Alignment: A Synapomorphy-Based Mulitple Sequence Alignment Method. Cladistics 19: 261-268.

Wilkinson, M. J.; J. G. Marshall; J. G. Lundberg, and M. H. Kreslavsky. 2010. Megafan environments in northern South America and their impact on Amazon Neogene aquatic ecosystems, pp. 63-84. In: Amazonia: landscape and species evolution. Hoorn, C. and F. Wesselingh (eds.). Oxford: Wiley-Blackwell. Chap. 10.

Williams, S. T. and T. Ozawa. 2006. Molecular phylogeny suggests polyphyly of both the turban shells (family Turbinidae) and the superfamily Trochoidea (Mollusca: Vetigastropoda). Molecular Phylogenetics and Evolution 39(1):

Zschoche, M.; J. N. Caira, and C. A. Fyler. 2011. A new species of Acanthobothrium van Beneden, 1850 (Tetraphyllidea: Onchobothriidae) from Pastinachus atrus (Macleay) (Batoidea: Dasyatidae) in Australian waters, with a reassessment of the host associations of Acanthobothrium spp. parasitising Pastinachus spp. Systematic Parasitology 78: 109-116. 



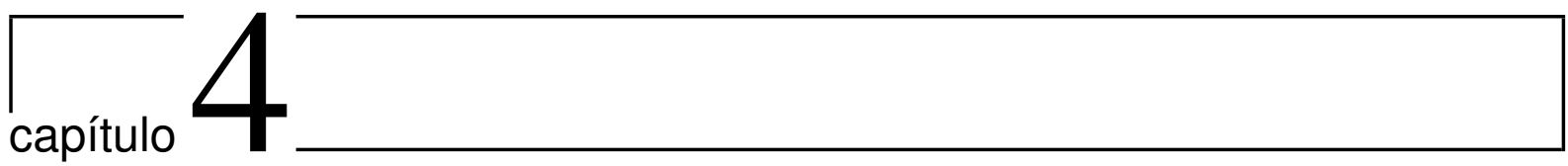

\section{Considerações finais}

\subsection{A origem de Acanthobothrium}

A revisão taxonômica de Acanthobothrium está além do escopo deste trabalho. Porém, inconcistências nomenclaturais (i.e., a falta de consenso a respeito da autoria do gênero, sua data de publicação, sua espécie-tipo e seu hospedeiro-tipo) atestam a necessidade de se revisar os atos nomenclaturais responsáveis pela disponibilização e tipificação de Acanthobothrium. Tal revisão foi impresssindível para delinearmos da melhor maneira possível nosso objeto de estudo. Verificou-se que a autoria de Acanthobothrium deve ser atribuída a Blanchard, 1848. A espécie-tipo do gênero é Acanthobothrium coronatum Blanchard, 1848. O nome válido de A. coronatum é Acanthobothrium corollatum (Abildgaard, 1790) n. comb. O hospedeiro-tipo de Acanthobothrium corresponde ao hospedeiro-tipo do sinônimo mais antigo de A. corollatum, Raja batis L. Esforços recentes em localizar o material tipo de A. corollatum provaram-se infrutíferos. No caso de que este material seja considerado perdido, não se aconselha a designação de um neótipo. Isto porque o neótipo deve estar relacionado ao conceito original de T. corollata, i.e., helmintos parasitas de R. batis portadores de quatro botrídeos, cada um portando um par de ganchos bifurcados. Como atualmente são conhecidas ao menos cinco espécies nominais de Acanthobothrium parasitas de R. batis (A. coronatum, A. icelandicum, A. parvum, A. rajaebatis, and A. septentrionale), a identificação daquela a qual Abildgaard (1790) atribuiu o nome de $T$. corollata é problemática, se não impossível.

\subsection{Acanthobothrium é monofilético?}

Apesar de já ter sido alvo de várias revisões taxonômicas (e.g., Linton, 1925; Baer, 1948; Goldstein, 1967; Williams, 1969; Campbell \& Beveridge, 2002) e uma hipótese filogenética representativa de suas espécies (Fyler, 2009), a monofilia de Acanthobothrium permanece discutível. Nossa análise não corrobora a monofilia do gênero devido em parte a seu 
relacionamento com helmintos biloculados com ganchos bifurcados do gênero Uncibilocularis. Nossos resultados sugerem a necessidade de se expandir a amostragem de membros de Uncibilocularis em uma análise filogenética que permita avaliar a delimitação deste táxon com base em sua consistência morfológica e monofilia em relação aos demais gêneros de Tetraphyllidea. É provável que os botrídios biloculados de Uncibilocularis, única característica que o distingue inequivocamente de Acanthobothrium, venha a ser considerada um caráter derivado dentro de Acanthobothrium. Neste caso, Uncibilocularis deverá ser considerado sinônimo júnior de Acanthobothrium, que deverá ser redescrito para acomodar espécies com um ou dois septos transversais por botrídio.

\subsection{Clados negligenciados}

A discussão das relações filogenéticas entre as espécies marinhas de Acanthobothrium foi extensivamente comentada por Fyler (2009) e foge do escopo desta contribuição. Entretanto, ao menos dois casos merecem destaque. Primeiramente, os terminais CF75 e CF77, identificados como "Acanthobothrium sp. $n$. 31" por Fyler (2009), estão mais relacionados com Proteocephalidea do que com as demais espécies de Acanthobothrium, indicando que é preciso cuidado na futura descrição desta espécie (veja resultados e Fyler, 2009). Em segundo lugar, é preciso chamar atenção para o clado formado pelos representantes de A. masnihae Fyler \& Caira, 2006 e A. saliki Fyler \& Caira, 2006. A monofilia recíproca de todas as espécies marinhas de Acanthobothrium é recuperada, com a exceção destas duas. Isto sugere que a delimitação destas duas espécies devem ser estudadas com maior cuidado. Este mesmo resultado é encontrado na hipótese filogenética proposta por Fyler (2009). A descrição destas espécies por Fyler \& Caira (2006) conta com respectivamente 17 e 14 espécimes coletados na mesma localidade e em um único hospedeiro. Todas as medidas relacionadas à escólex, botrídios e ganchos destas duas espécies apresentam sobreposição. Seu comprimento total e várias outras medidas associadas às proglótides também não são taxonomicamente informativas para distinguir A. masnihae de A. saliki. Entretanto, ambas diferem quanto ao número de proglótides (respectivamente $31,4 \pm 5,1$ e 14,4 $\pm 2,9)^{1}$, comprimento da proglótide terminal (respectivamente $373,5 \mu \mathrm{m} \pm 57,2$ e $587,2 \mu \mathrm{m} \pm 117,6$ ), número de testículos (respectivamente $7,1 \pm 1,3 \mathrm{e}$ 20,6 $\pm 1,9$ ), comprimento dos testículos (respectivamente 19,5 $\mu \mathrm{m} \pm 2,5$ e 27,4 $\mu \mathrm{m} \pm 5,0$ ), largura dos testículos (respectivamente $33,1 \mu \mathrm{m} \pm 4,4$ e 47,3 $\mu \mathrm{m} \pm 8,5$ ), largura do saco do cirro (respectivamente $55,2 \mu \mathrm{m} \pm 4,7$ e $63,8 \mu \mathrm{m} \pm 3,5$ ) e largura do ovário (respectivamente $70,4 \mu \mathrm{m} \pm 7,0$ e $98,3 \mu \mathrm{m} \pm 8,0$ ). A. masnihae ainda difere de A. saliki por apresentar testículos parcialmente ou completamente atrofiados nas proglótides maduras, campo de testículos pósovarianos e ovário assimétrico.

\footnotetext{
${ }^{1}$ As medidas são dadas como média e desvio padrão; mais detalhes em Fyler \& Caira (2006:107, Tabela 1).
} 
Apesar de não recuperarmos a monofilia recíproca de A. masnihae e A. saliki, nossa análise não deve ser tomada como uma indicação de que ambas as espécies devam ser sinonimizadas, especialmente dadas suas diferenças morfológicas. Nossa sugestão neste caso é apenas que se expandam as amostragens para ambas as espécies de modo a se aprimorar o registro de sua plasticidade fenotípica.

\subsection{Relações filogenéticas entre Acanthobothrium dulcícolas}

Brooks et al. (1981) e Fyler (2009) foram os únicos autores a analisarem espécies dulcícolas de Acanthobothrium dentro de um contexto filogenético. Entretanto, Brooks et al. jamais descreveram os carácteres empregados em sua análise nem mesmo especificaram os métodos empregados em suas análises filogenéticas, o que dificulta a avaliação de seus resultados. $\mathrm{O}$ trabalho de Fyler é muito mais robusto neste sentido, entretanto apenas três terminais de duas espécies nominais de Acanthobothrium parasitas de potamotrigonídeos foram contemplados pela autora. Este trabalho, portanto, apresenta a primeira avaliação explícita do posicionamento filogenético de linhagens de Acanthobothrium parasitas de potamotrigonídeos.

Com base no posicionamento filogenético de novas linhagens descobertas por Cardoso (2010), chegamos à conclusão de que, ao contrário do sugerido por Brooks et al. e reiterado por Fyler, as linhagens dulcícolas de Acanthobothrium não constituem um grupo monofilético. Acanthobothrium sp. 2 está mais relacionada à congêneres marinhos da costa do Senegal do que com o restante das espécies de água doce (veja Fig. 4). Com base nestes resultados, podemos discutir aspectos do processo de colonização do sistema fluvial neotropical, padrões de variação morfológica intraespecífica e padrões de especificidade ao hospedeiro.

A mono/para/polifilia dos parasitas não necessariamente implica na monofilia/polifilia do hospedeiro (Lovejoy, 1997). Atualmente, a monofilia dos potamotigonídeos é fortemente corroborada (Rosa, 1985; Lovejoy, 1996; de Carvalho et al., 2004) e há diversos trabalhos registram duas ou mais linhagens separadas de Acanthobothrium ocorrendo em simpatria dentro de uma única espécime de hospedeiro (Fyler \& Caira, 2006; Reyda \& Caira, 2006; Fyler et al., 2009; ver relacionamentos filogenéticos em Fyler, 2009, e em nosso cladograma, Apêndice A.9: Figura A.1). Assim, propomos que a para/polifilia de Acanthobothrium parasitas de arraias de água doce é explicada por duas ou mais linhagens independentes de Acanthobothrium infectando o ancestral dos potamotrigonídeos.

Recuperamos a monofilia recíproca de Acanthobothrium sp. 1, Acanthobothrium sp. 2 e A. terezae ( $\sin$. A. ramiroi) conforme a delimitação destas espécies proposta por Cardoso. Este resultado sugere que a grande variabilidade morfológica observada dentro destas espécies assim como sua baixa especificidade ao hospedeiro não são artefatos txonômicos. A variabilidade morfológica documentada e os padrões de especificidade observado se repetem dentre as 
demais linhagens de tetrafilídeos parasitas de potamotrigonídeos (como em Rhinebothrium; Reyda \& Marques, 2011) e difere significativamente do que se reporta para seus congêneres marinhos. Neste momento, não está claro se os padrões conflitantes são causados por características específicas do sistema potamotrigonídeos/parasitas (ver Reyda \& Marques, 2011) ou um reflexo do baixo número de espécimes empregados na descrição de espécies de tetrafilídeos marinhos, que frequentemente não ultrapassa 20 exemplares.

Ademais, não fomos capazes de recuperar a monofilia recíproca de A. quinonesi (sin. A. regoi e A. peruviense) e $A$. amazonensis. Hoje, a única característica que distingue estas espécies é o formato do saco do cirro: triangular ou em forma de "T" em A. quinonesi e reto em $A$. amazonensis. Entretanto, Cardoso já demonstrou que esta característica é variável e a diferença observada atualmente pode ser um reflexo do pequeno número de espécimes de A. amazonensis que foram examinados por Cardoso (apenas 4 exemplares, em comparação com mais de 300 exemplares examinados para A. quinonesi). A decisão a respeito da sinonimização destas duas espécies carece, portanto, da examinação material adicional para A. amazonensis.

Reiteramos a conclusão central de Cardoso (2010), de que taxonomistas devem ter cautela no uso de dados morfométricos e merísticos na diagnose de espécies que são descritas com base um material biológico limitado. Para se acessar a variabilidade morfológica de tetrafilídeos, em geral, é requerido o aumento do tamanho amostral considerando diferentes hospedeiros e áreas, uma vez que a representatividade biogeográfica é fundamental para a compreensão da biodiversidade.

\section{Referências}

Abildgaard, P. C. 1790. Almindelige Betragtninger over Indvolde-Orme, Bemærkninger ved Hundsteilens Bændelorm, og Beskrivelse med Figurer af nogle nye Bændelorme. Skrivter af Naturhistorie-Selskabet 1(1): 26-64.

Baer, J. B. 1948. Contributions a l'étude des cestodes de Sélaciens. I-IV, Bulletin de la Société neuchateloise des Sciences naturelles 71: 63-122.

Blanchard, C. É. 1848. Sur l'organisation des vers. Annales des Sciences Naturelles 10: 321364. URL: http: / / www.biodiversitylibrary.org/item/ 49250.

Brooks, D. R.; T. B. Thorson \& M. A. Mayes. 1981. Freshwater stingrays (Potamotrygonidae) and their helminth parasites: testing hipotesis of evolution and coevolution. Em: Advances in cladistics. Funk, V. A. \& D. R. Brooks (eds.). New York: New York Botanical Garden, pp. 145-175.

Campbell, R. A. \& I. Beveridge. 2002. The genus Acanthobothrium (Cestoda: Tetraphyllidea: Onchobothriidae) parasitic in Australian elasmobranch fishes. Invertebrate Systematics 16: 237-344. 
Cardoso Jr., M. 2010. Taxonomia das linhagens de Acanthobothrium van Beneden, 1850 (Eucestoda: Tetraphyllidea) parasitas de Potamotrygonidae (Chondrichthyes: Myliobatiformes). Diss. de mestrado. São Paulo: Universidade de São Paulo. 69 pp.

de Carvalho, M. R.; J. G. Maisey \& L. Grande. 2004. Freshwater stingrays of the Green River formation of Wyoming (early Eocene), with the description of a new genus and species and an analysis of its phylogenetic relationships (Chondrichthyes: Myliobatiformes). Bulletin of the American Museum of Natural History 284: 1-136.

Fyler, C. A. 2009. Systematics, biogeography and character evolution in the tapeworm genus Acanthobothrium van Beneden, 1850. Tese de doutorado. Storrs: University of Connecticut. $168 \mathrm{pp}$.

Fyler, C. A. \& J. N. Caira. 2006. Five new species of Acanthobothrium (Tetraphyllidea: Onchobothriidae) from the freshwater stingray Himantura chaophraya (Batoidea: Dasyatidae) in Malaysian Borneo. Journal of Parasitology 92(1): 105-125.

Fyler, C. A.; J. N. Caira \& K. Jensen. 2009. Five new especies of Acanthobothrium (Cestoda: Tetraphyllidea) from an unusual species of Himantura (Rajiformes: Dasyatidae) from northern Australia. Folia Parasitologica 56(2): 107-128.

Goldstein, R. J. 1967. The genus Acanthobothrium Van Beneden, 1849 (Cestoda: Tetraphyllidea). The Journal of Parasitology 53(3): 455-483.

Linton, E. 1925. Notes on cestode parasites of sharks and skates. Proceedings of the United States National Museum 64: 1-114.

Lovejoy, N. R. 1996. Systematic of myliobatoid elasmobranchs: whith emphasis on phylogeny and historical biogeography of Neotropical freshwater stingrays (Potamotrigonidae: Rajiformes). Zoological Journal of the Linnean Society 117: 207-257.

Lovejoy, N. R. 1997. Stingrays, parasites, and neotropical biogeography: a closer look at Brooks et al.'s hypothesis concerning the origins of neotropical freshwater rays (Potamotrygonidae). Systematic Biology 46: 218-230.

Reyda, F. B. \& J. N. Caira. 2006. Five new species of Acanthobothrium (Cestoda: Tetraphyllidea) from Himantura uarnacoides (Myliobatiformes: Dasyatidae) in Malaysian Borneo. Comparative Parasitology 73(1): 49-71.

Reyda, F. B. \& F. P. L. Marques. 2011. Diversification and species boundaries of Rhinebothrium (Cestoda; Rhinebothriidea) in South American freshwater stingrays (Batoidea; Potamotrygonidae). PLoS ONE 6(8): e22604. DOI: 10 . 1371 / journal. pone.0022604.

Rosa, R. S. 1985. A systematic revision of the South American freshwater stingrays (Chondrichthyes: Potamotrigonidae). Tese de doutorado. Williamsburg: The College of Willian e Mary. 542 pp. 
Machado, D.J. Dissertação de Mestrado, 2012

Williams, H. H. 1969. The genus Acanthobothrium Beneden 1849 (Cestoda: Tetraphyllidea). Nytt Magazine of Zoology 17: 1-56. 


\section{Resumo}

Primeiramente, apresentamos esclarecimentos sobre a origem do táxon Acanthobothrium. A autoria do gênero deve ser creditada à Blanchard em 1848, ocasião na qual este autor disponibilizou a primeira espécie válida para o gênero, Acanthobothrium coronatum. A espécie tipo de Acanthobothrium é A. coronatum Blanchard, 1848, um sinônimo júnior de $A$. corollatum (Abilgaard, 1790). Também foi identificada Raja batis L. como hospedeiro-tipo do gênero. A seguir, empregamos a otimização direta de 16S, 28S, and ITS1 rDNA para avaliar o posicionamento filogenético das linhagens de Acanthobothrium parasitas de arraias de água doce (Potamotrygonidae). As delimitações morfológica das espécies Acanthobothrium sp. 1, Acanthobothrium sp. 2 e A. terezae (sin. A. ramiroi) são validadas pela monofilia recíproca destas linhagens. São apresentados indícios de que A. amazonensis é sinônimo de A. quinonesi. Nossos resultados reforçam a ideia de que tetrafilídeos parasitas de potamotrigonídeos apresentam grande variação morfológica intraespecífica e baixa especificidade (em contraste com seus congêneres marinhos). A. quinonesi é grupo irmão do clado que compreende $A$. terezae e Acanthobothrium. sp. 1. Acanthobothrium sp. 2 está mais relacionados com seus congêneres marinhos do que com as demais espécies parasitas de potamotrigonídeos, o que sugere que a colonização da água doce por Acanthobothrium se deu através de pelo menos duas linhagens ancestrais independentes que infectavam o ancestral exclusivo comum das arrais de água doce.

Palavras-chave: Acanthobothrium, sistemática, homologia dinâmica. 



\begin{abstract}
We clarify some major points in the taxonomic history of Acanthobothrium. The authorship of the genus must be given to Blanchard in 1848, ocasion in which its first species, Acanthobothrium coronatum, was created. Therefore, the type species of Acanthobothrium is A. coronatum Blanchard, 1848, a junior synonym of A. corollatum (Abildgaard, 1790). Both Acanthothrothrium and A. corollatum have their concepts attached to armed tapeworms parasites of Raja batis L., their type host. Following we provided a phylogenetic analysis based on the direct optimization of 16S, 28S, and ITS1 rDNA to access the phylogentic position of freshwater Acanthobothrium lineages. The current morphological delimitations of Acanthobothrium sp. 1, Acanthobothrium sp. 2, A. terezae (syn. A. ramiroi) and A. quinonesi (syn. A. regoi and $A$. peruviense) are corroborated. There are indications that $A$. amazonensis should be considered synonym of A quinonesi. Our results provide additionl evidence to support the idea that freshwater lineages of tetraphyllideans (as opposed to marine tetraphyllideans) presents great intra-specific morphological variation and low host specificity. A. quinonesi is sister group of a clade that comprises A. terezae and Acanthobothrium. sp. 1. Acanthobothrium sp. 2 is more related to marine species of Acanthobothrium than to freshwater congenerics. This suggests that the colonization of the freshwater system by Acanthobothrium is likely to have occur via at least two separate lineages of Acanthobothrium infecting the exclusive common ancestor of the potamotrygonids, which would in time be responsible for the existence of two distinct clades of freshwater species of Acanthobothrium.
\end{abstract}

Keywords: Acanthobothrium, systematics, dynamic homology. 

Anexos 



\section{A.1 Collection of freshwater stingrays}

Table A.1: Potamotrygonid stingray species and localities sampled in this study.

\begin{tabular}{|c|c|c|c|c|c|c|c|}
\hline Field code $\dagger$ & Sub-basin & Water body & $\begin{array}{l}\text { Municipality, state and } \\
\text { country }\end{array}$ & Lat. & Long. & $\begin{array}{l}\text { Collection } \\
\text { date }\end{array}$ & Species \\
\hline \multicolumn{8}{|c|}{ Amazon River System } \\
\hline MT05-033 & & Jamanxim River & Novo Progresso, PA, Brazil & -7.16 & -55.43 & $12 / 13 / 2005$ & Potamotrygon sp. (jabuti) \\
\hline PA07-075 & Lower Amazon & Igarapé do Urubu & Cachoeira do Arari, PA - BR & -1.00 & -48.96 & 08/29/2007 & Po. motoro \\
\hline RN05-085 & Negro/Branco & Negro River & Barcelos, AM, Brazil & -0.67 & -63.20 & 02/04/2005 & Po. motoro \\
\hline RN11-002 & & Negro River & Barcelos, AM, Brazil & -0.96 & -62.94 & 01/09/2011 & Pa. aiereba \\
\hline RN11-023 & & Negro River & Barcelos, AM, Brazil & -0.96 & -62.94 & 01/10/2011 & Po. schroederi \\
\hline RN11-029 & & Negro River & Barcelos, AM, Brazil & -0.96 & -62.94 & 01/10/2011 & Po. orbignyi \\
\hline RN11-034 & & Negro River & Barcelos, AM, Brazil & -0.96 & -62.94 & $01 / 12 / 2011$ & Po. schroederi \\
\hline RN11-037 & & Negro River & Barcelos, AM, Brazil & -0.83 & -63.04 & $01 / 12 / 2011$ & Pa. aiereba \\
\hline RN11-050 & & Negro River & Barcelos, AM, Brazil & -0.66 & -63.02 & $01 / 14 / 2011$ & Po. schroederi \\
\hline RN11-053 & & Negro River & Barcelos, AM, Brazil & -0.66 & -63.02 & $01 / 14 / 2011$ & Po. motoro \\
\hline RN11-054 & & Negro River & Barcelos, AM, Brazil & -0.66 & -63.02 & 01/14/2011 & Po. motoro \\
\hline RN11-056 & & Negro River & Barcelos, AM, Brazil & -0.66 & -63.02 & $01 / 14 / 2011$ & Po. motoro \\
\hline
\end{tabular}


Table A.1 - Continued from previous page

\begin{tabular}{|c|c|c|c|c|c|c|c|}
\hline Field code $\dagger$ & Sub-basin & Water body & $\begin{array}{l}\text { Municipality, state and } \\
\text { country }\end{array}$ & Lat. & Long. & $\begin{array}{l}\text { Collection } \\
\text { date }\end{array}$ & Species \\
\hline RN11-057 & & Negro River & Barcelos, AM, Brazil & -0.66 & -63.02 & $01 / 15 / 2011$ & Po. motoro \\
\hline RN11-058 & & Negro River & Barcelos, AM, Brazil & -0.96 & -62.94 & $01 / 16 / 2011$ & Po. schroederi \\
\hline RN11-063 & & Negro River & Barcelos, AM, Brazil & -0.96 & -62.94 & $01 / 16 / 2011$ & Po. schroederi \\
\hline VZ11-012 & Sinamaica lagoon & Limón River & Venezuela & 11.04 & -71.86 & $02 / 18 / 2011$ & Po. yepezi \\
\hline VZ11-013 & & Limón River & Venezuela & 11.04 & -71.86 & $02 / 18 / 2011$ & Po. уереzi \\
\hline VZ11-018 & & Limón River & Venezuela & 11.04 & -71.86 & $02 / 18 / 2011$ & Po. yepezi \\
\hline VZ11-025 & Apure & Apure River & Aguaro-Guaritico, Venezuela & 7.89 & -68.88 & $02 / 23 / 2011$ & Pa. aiereba \\
\hline VZ11-026 & & Apure River & Aguaro-Guaritico, Venezuela & 7.89 & -68.88 & $02 / 23 / 2011$ & Po. cf. orbignyi \\
\hline VZ11-029 & & Apure River & Aguaro-Guaritico, Venezuela & 7.89 & -68.88 & $02 / 23 / 2011$ & Po. cf. orbignyi \\
\hline VZ11-031 & & Apure River & Aguaro-Guaritico, Venezuela & 7.89 & -68.88 & $02 / 23 / 2011$ & Pa. aiereba \\
\hline VZ11-033 & & Apure River & Aguaro-Guaritico, Venezuela & 7.89 & -68.88 & $02 / 23 / 2011$ & Pa. aiereba \\
\hline VZ11-034 & & Apure River & Aguaro-Guaritico, Venezuela & 7.89 & -68.88 & $02 / 23 / 2011$ & Po. cf. orbignyi \\
\hline \multicolumn{8}{|c|}{ de La Plata River System } \\
\hline MS10-005 & Paraguay River & Salobra River & Miranda, MS, Brazil & -20.21 & -56.50 & $07 / 11 / 2010$ & Po. motoro \\
\hline MS10-007 & & Salobra River & Miranda, MS, Brazil & -20.21 & -56.50 & $07 / 11 / 2010$ & Po. motoro \\
\hline MS10-014 & & Salobra River & Miranda, MS, Brazil & -20.21 & -56.50 & $07 / 11 / 2010$ & Po. cf. motoro \\
\hline MS10-018 & & Salobra River & Miranda, MS, Brazil & -20.21 & -56.50 & $07 / 12 / 2010$ & Po. motoro \\
\hline MS10-021 & & Salobra River & Miranda, MS, Brazil & -20.21 & -56.50 & $07 / 12 / 2010$ & Po. cf. motoro \\
\hline MS10-026 & & Salobra River & Miranda, MS, Brazil & -20.21 & -56.50 & $07 / 13 / 2010$ & Po. motoro \\
\hline MS10-028 & & Salobra River & Miranda, MS, Brazil & -20.21 & -56.50 & $07 / 13 / 2010$ & Po. histrix \\
\hline MS10-035 & & Salobra River & Miranda, MS, Brazil & -20.21 & -56.50 & $07 / 13 / 2010$ & Po. cf. motoro \\
\hline MS10-041 & & Salobra River & Miranda, MS, Brazil & -20.21 & -56.50 & $07 / 13 / 2010$ & Po. histrix \\
\hline
\end{tabular}


Table A.1 - Continued from previous page

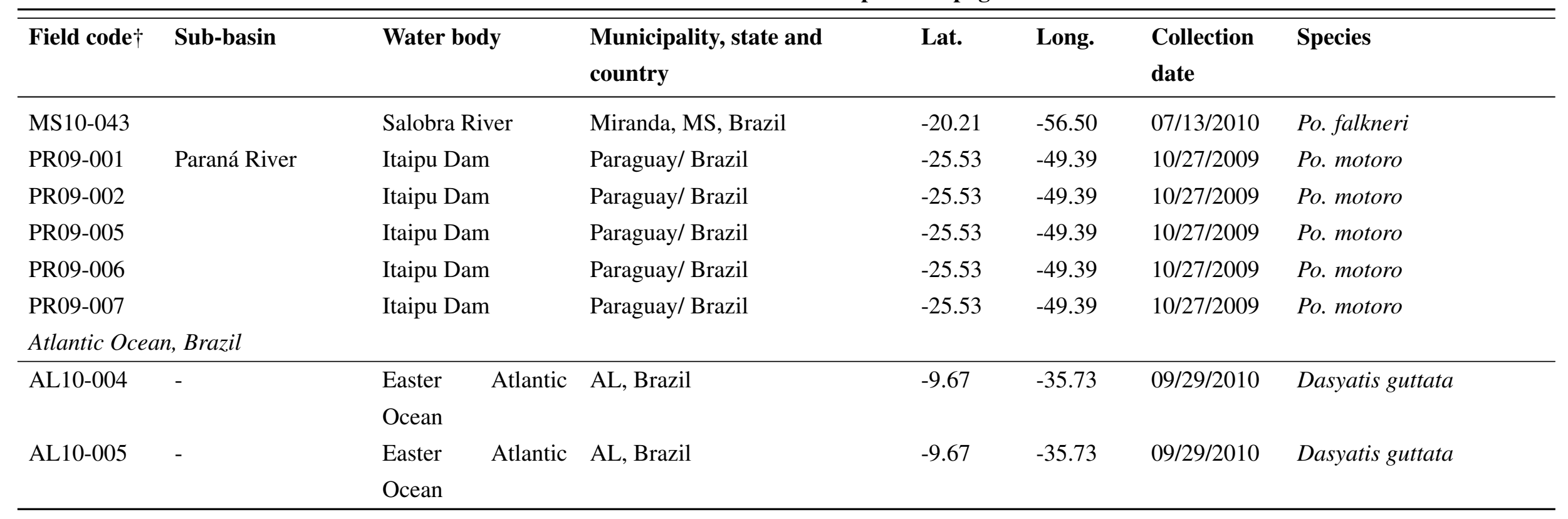

$†$ Field codes correspond to locations shown in Figure 1. For further information, lock the online Host-Parasite collection (www.ib.usp.br/hpc/hpc_index.html). 


\section{A.2 Coleta e fixação do material biológico}

Os espécimes de potamotrigonídeos amostrados neste trabalho foram coletados com diversos métodos, tais como espinhéis, redes e arpão.

Após a coleta dos hospedeiros, aqueles submetidos à necropsia sofreram eutanásia pela injeção de solução saturada de benzocaína em etanol $92 \%$ na região cardíaca. As válvulas espirais foram removidas com hemostatos e bisturis, fixadas em etanol 95-100\% e armazenadas em gelo.

Em laboratório, as válvulas foram armazenadas a $-20^{\circ} \mathrm{C}$ até a triagem. As válvulas foram triadas sob esteromicroscópio para a remoção dos espécimes de parasitas, os quais foram posteriormente estocados a $-70^{\circ} \mathrm{C}$ até a seleção para exatração de DNA genômico e preparação de lâminas de hologenóforos (Anexo A.3). 


\section{A.3 Preparação de lâminas de hologenóforos}

- Hologenóforos em etanol 100\% foram hidratação em séries alcoólicas regressivas

- Etanol 70\%: 3 min

- Etanol 50\%: 3 min

- Etanol 30\%: 3 min

- Água destilada I: 3 min

- Água destilada II: 3 min

- Exemplares hidratados foram corados com Hematoxilina de Delafield por 30-120 min

- Amostras coradas foram hidratadas em séries alcóolicas progressivas

- Etanol 30\%: 3 min

- Etanol 50\%: 3 min

- Etanol 70\%: 3 min

- Neste ponto, sempre que necessário, o excesso de corante foi removido

* Manter a amostra corada em solução alcoólica (etanol 70\%) de $\mathrm{HCl} 1 \%$ até a remoção do excesso de corante

* Transferir para solução alcóolica (etanol 70\%) de hidróxido de amônia 2\% por $1 \mathrm{~min}$

- Etanol 100\% I: $3 \mathrm{~min}$

- Etanol 100\% II: 3min

- Amostras coradas e desidratadas foram diafanizadas em Salicilato de Metila

- Salicilato de Metila 75\%: $3 \mathrm{~min}$

- Salicilato de Metila 100\% I: $3 \mathrm{~min}$

- Salicilato de Metila 100\% II: 3min

- Hologenóforos foram montados em lâmina e lamínula com Bálsamo do Canadá 


\section{A.4 Original cestode material collected in South America}

Table A.2: Original cestode material collected in South America. Cestodes sequenced, with taxon names, hosts, collection localities, and museum voucher numbers for hologenophores.

\begin{tabular}{|c|c|c|c|c|c|c|c|c|}
\hline $\begin{array}{l}\text { Molecular } \\
\text { code }\end{array}$ & Field code $\dagger$ & MZUSP & Species & Host & Locality & $16 S$ & $\begin{array}{c}\text { Genes } \\
28 S\end{array}$ & ITSI \\
\hline A006 & PA07-075.20 & 7349 & Acanthobothrium cf. amazonensis & Po. motoro & $\begin{array}{l}\text { Igarapé do Urubu, Cachoeira do } \\
\text { Arari, PA - BR }\end{array}$ & & & - \\
\hline A017 & MT05-009.06 & 7358 & Acanthobothrium sp. & Potamotrygon sp. (negra) & $\begin{array}{l}\text { Teles Pires River, Alta Floresta, } \\
\text { MT - BR }\end{array}$ & • & & - \\
\hline $\mathrm{A} 023$ & PR09-001.01 & 7362 & Acanthobothrium cf. quinonesi & Po. motoro & $\begin{array}{l}\text { Paraná River, Foz do Iguaçu, PR } \\
\text { - BR }\end{array}$ & - & & - \\
\hline A026 & PR09-006.01 & 7365 & Acanthobothrium sp. & Po. motoro & $\begin{array}{l}\text { Paraná River, Foz do Iguaçu, PR } \\
\text { - BR }\end{array}$ & & • & - \\
\hline A027 & PR09-007.01 & 7366 & Acanthobothrium cf. quinonesi & Po. motoro & $\begin{array}{l}\text { Paraná River, Foz do Iguaçu, PR } \\
\text { - BR }\end{array}$ & & • & • \\
\hline $\mathrm{A} 028$ & PR09-001.02 & 7367 & Acanthobothrium cf. quinonesi & Po. motoro & $\begin{array}{l}\text { Paraná River, Foz do Iguaçu, PR } \\
\text { - BR }\end{array}$ & & & - \\
\hline $\mathrm{A} 032$ & PR09-005.02 & 7370 & Acanthobothrium sp. & Po. motoro & $\begin{array}{l}\text { Paraná River, Foz do Iguaçu, PR } \\
\text { - BR }\end{array}$ & & • & - \\
\hline
\end{tabular}


Table A.2 - Continued from previous page

\begin{tabular}{|c|c|c|c|c|c|c|c|c|}
\hline $\begin{array}{l}\text { Molecular } \\
\text { code }\end{array}$ & Field code $\dagger$ & MZUSP & Species & Host & $\begin{array}{l}\text { Marine water body or } \\
\text { freshwater river (system) }\end{array}$ & & $\begin{array}{l}\text { Gene } \\
28 S\end{array}$ & es \\
\hline A034 & PR09-006.02 & 7372 & Acanthobothrium quinonesi & Po. motoro & $\begin{array}{l}\text { Paraná River, Foz do Iguaçu, PR } \\
\text { - BR }\end{array}$ & • & $\bullet$ & $\bullet$ \\
\hline A035 & PR09-006.03 & 7373 & Acanthobothrium cf. quinonesi & Po. motoro & $\begin{array}{l}\text { Paraná River, Foz do Iguaçu, PR } \\
\text { - BR }\end{array}$ & & $\bullet$ & $\bullet$ \\
\hline A036 & PR09-006.04 & 7374 & Acanthobothrium cf. amazonensis & Po. motoro & $\begin{array}{l}\text { Paraná River, Foz do Iguaçu, PR } \\
\text { - BR }\end{array}$ & • & $\bullet$ & • \\
\hline A037 & PR09-006.05 & 7375 & Acanthobothrium cf. quinonesi & Po. motoro & $\begin{array}{l}\text { Paraná River, Foz do Iguaçu, PR } \\
\text { - BR }\end{array}$ & & • & • \\
\hline A038 & PR09-006.06 & 7376 & Acanthobothrium quinonesi & Po. motoro & $\begin{array}{l}\text { Paraná River, Foz do Iguaçu, PR } \\
\text { - BR }\end{array}$ & & • & • \\
\hline A039 & PR09-006.07 & 7377 & Acanthobothrium quinonesi & Po. motoro & $\begin{array}{l}\text { Paraná River, Foz do Iguaçu, PR } \\
\text { - BR }\end{array}$ & & $\bullet$ & $\bullet$ \\
\hline A047 & MS10-014.01 & 7385 & Acanthobothrium cf. quinonesi & Potamotrygon sp. & $\begin{array}{l}\text { Salobra River, Miranda, MS - } \\
\text { BR }\end{array}$ & & • & • \\
\hline A048 & MS10-014.02 & 7386 & Acanthobothrium cf. quinonesi & Potamotrygon sp. & $\begin{array}{l}\text { Salobra River, Miranda, MS - } \\
\text { BR }\end{array}$ & & $\bullet$ & • \\
\hline A049 & MS10-018.01 & 7387 & Acanthobothrium cf. quinonesi & Po. motoro & $\begin{array}{l}\text { Salobra River, Miranda, MS - } \\
\text { BR }\end{array}$ & & $\bullet$ & $\bullet$ \\
\hline
\end{tabular}


Table A.2 - Continued from previous page

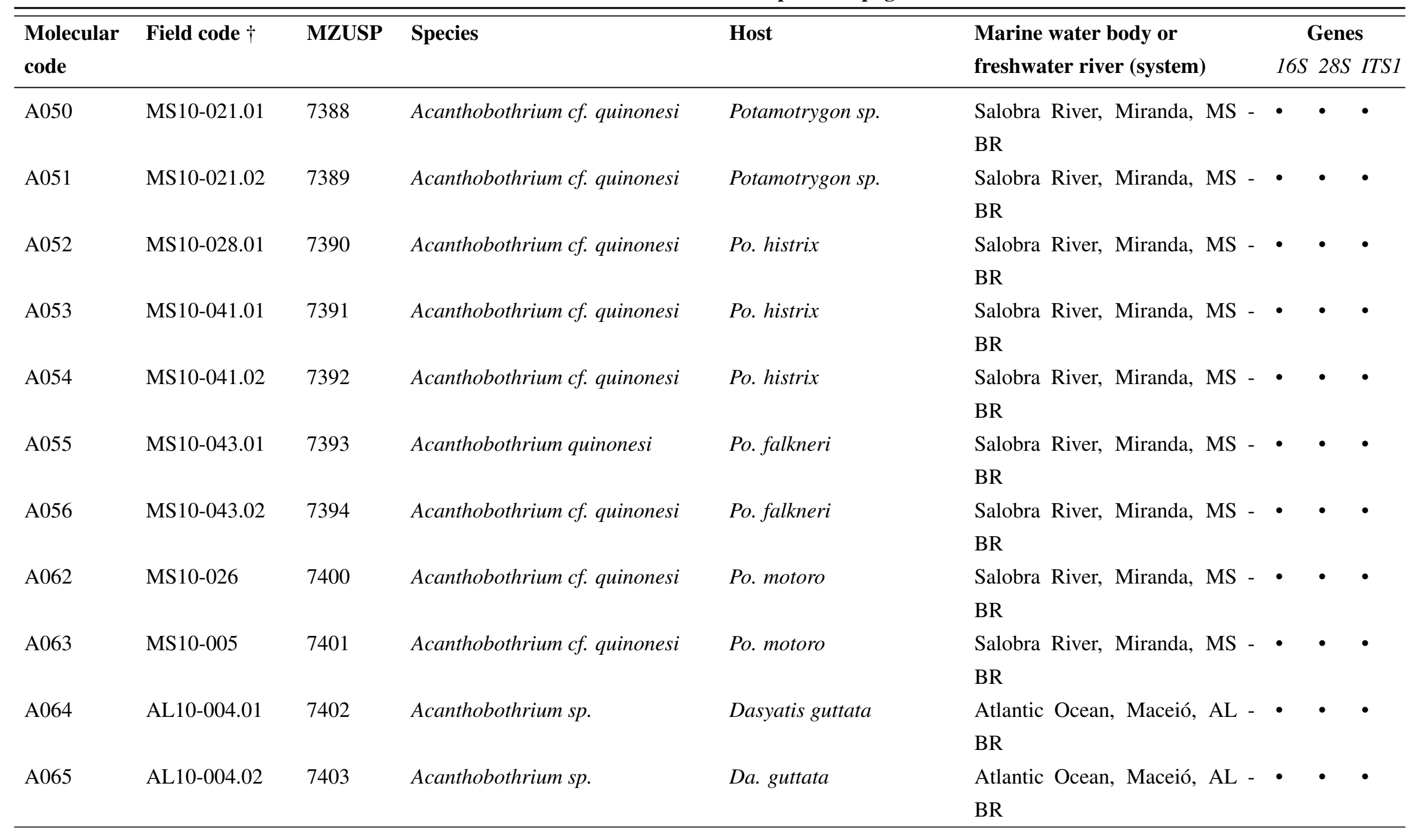


Table A.2 - Continued from previous page

\begin{tabular}{|c|c|c|c|c|c|c|c|}
\hline $\begin{array}{l}\text { Molecular } \\
\text { code }\end{array}$ & Field code $\dagger$ & MZUSP & Species & Host & $\begin{array}{l}\text { Marine water body or } \\
\text { freshwater river (system) }\end{array}$ & $\begin{array}{r}\text { Gene } \\
16 S 28 S\end{array}$ & ITS1 \\
\hline A066 & AL10-005.01 & 7404 & Acanthobothrium sp. & Da. guttata & $\begin{array}{l}\text { Atlantic Ocean, Maceió, AL - } \\
\text { BR }\end{array}$ & • & - \\
\hline A067 & AL10-005.02 & 7405 & Acanthobothrium sp. & Da. guttata & $\begin{array}{l}\text { Atlantic Ocean, Maceió, AL - } \\
\text { BR }\end{array}$ & - & $\bullet$ \\
\hline A069 & MS10-007.01 & 7406 & Acanthobothrium quinonesi & Po. motoro & $\begin{array}{l}\text { Salobra River, Miranda, MS - } \\
\text { BR }\end{array}$ & • & • \\
\hline A070 & MS10-035.01 & 7407 & Acanthobothrium cf. quinonesi & Po. motoro & $\begin{array}{l}\text { Salobra River, Miranda, MS - } \\
\text { BR }\end{array}$ & $\bullet$ & $\bullet$ \\
\hline A076 & МT05-033.07 & 7408 & Acanthobothrium cf. amazonensis & Potamotrygon sp. (tpj1) & $\begin{array}{l}\text { Jamanxim River, } \quad \text { Novo } \\
\text { Progresso, PA - BR }\end{array}$ & - & • \\
\hline A077 & MT05-033.09 & 7409 & Acanthobothrium cf. quinonesi & Potamotrygon sp. (tpj1) & $\begin{array}{l}\text { Jamanxim River, } \\
\text { Progresso, PA - BR }\end{array}$ & • & - \\
\hline A097 & VZ11-026.20 & 7419 & Acanthobothrium cf. sp. 1 & Po. yepezi & Apure/Guaritico river - VE & $\cdot$ & $\bullet$ \\
\hline A098 & VZ11-013.01 & 7420 & Acanthobothrium cf. quinonesi & Po. yepezi & Limón River - VE & • & $\bullet$ \\
\hline A099 & VZ11-018.02 & 7421 & Acanthobothrium cf. quinonesi & Po. yepezi & Limón River - VE & • & $\bullet$ \\
\hline A100 & VZ11-018.04 & 7422 & Acanthobothrium cf. quinonesi & Po. yepezi & Limón River - VE & • & $\bullet$ \\
\hline A101 & VZ11-012.01 & 7423 & Acanthobothrium cf. quinonesi & Po. yepezi & Limón River - VE & • & - \\
\hline A102 & VZ11-012.04 & 7424 & Acanthobothrium cf. quinonesi & Po. yepezi & Limón River - VE & $\cdot$ & $\bullet$ \\
\hline A103 & VZ11-034.01 & 7425 & Acanthobothrium terezae & Po. orbignyi & Apure River - VE & & $\bullet$ \\
\hline
\end{tabular}


Table A.2 - Continued from previous page

\begin{tabular}{|c|c|c|c|c|c|c|c|c|}
\hline $\begin{array}{l}\text { Molecular } \\
\text { code }\end{array}$ & Field code $\dagger$ & MZUSP & Species & Host & $\begin{array}{l}\text { Marine water body or } \\
\text { freshwater river (system) }\end{array}$ & $16 S$ & $\begin{array}{l}\text { Gene: } \\
28 S\end{array}$ & $\begin{array}{l}\mathbf{s} \\
\text { ITS1 }\end{array}$ \\
\hline A104 & VZ11-034.04 & 7426 & Acanthobothrium sp. 1 & Po. orbignyi & Apure River - VE & & - & $\bullet$ \\
\hline A107 & VZ11-025.39 & 7429 & Acanthobothrium sp. 1 & Pa. aiereba & Apure River - VE & $\bullet$ & & $\bullet$ \\
\hline A108 & VZ11-025.40 & 7430 & Acanthobothrium sp. 1 & Pa. aiereba & Apure River - VE & $\bullet$ & $\bullet$ & $\bullet$ \\
\hline A110 & VZ11-033.03 & 7432 & Acanthobothrium sp. 1 & Pa. aiereba & Apure River - VE & $\bullet$ & - & $\bullet$ \\
\hline A111 & VZ11-033.06 & 7433 & Acanthobothrium sp. 1 & Pa. aiereba & Apure River - VE & $\bullet$ & $\bullet$ & $\bullet$ \\
\hline A112 & VZ11-031.01 & 7434 & Acanthobothrium terezae & Pa. aiereba & Apure River - VE & $\bullet$ & & $\bullet$ \\
\hline A113 & VZ11-031.13 & 7435 & Acanthobothrium sp. 1 & Pa. aiereba & Apure River - VE & $\bullet$ & $\bullet$ & $\bullet$ \\
\hline A114 & VZ11-026.04 & 7436 & Acanthobothrium sp. 1 & Po. orbignyi & Apure River - VE & $\bullet$ & $\bullet$ & $\bullet$ \\
\hline A115 & VZ11-029.01 & 7437 & Acanthobothrium cf. quinonesi & Po. orbignyi & Apure River - VE & - & - & \\
\hline A116 & RN11-043.02 & 7438 & Acanthobothrium amazonensis & Po. schroederi & Negro River, Barcelos, AM - BR & $\bullet$ & & $\bullet$ \\
\hline A117 & RN11-043.03 & 7439 & Acanthobothrium amazonensis & Po. schroederi & Negro River, Barcelos, AM - BR & $\bullet$ & $\bullet$ & $\bullet$ \\
\hline A118 & RN11-058.04 & 7440 & Acanthobothrium sp. 2 & Po. schroederi & Negro River, Barcelos, AM - BR & $\bullet$ & $\bullet$ & \\
\hline A120 & RN11-058.01 & 7441 & Acanthobothrium cf. quinonesi & Po. schroederi & Negro River, Barcelos, AM - BR & & $\bullet$ & $\bullet$ \\
\hline A121 & RN11-058.03 & 7442 & Acanthobothrium cf. sp. 2 & Po. schroederi & Negro River, Barcelos, AM - BR & $\bullet$ & $\bullet$ & $\bullet$ \\
\hline A122 & RN11-058.06 & 7443 & Acanthobothrium sp. 1 & Po. schroederi & Negro River, Barcelos, AM - BR & $\bullet$ & $\bullet$ & $\bullet$ \\
\hline A124 & RN11-002.02 & 7445 & Acanthobothrium cf. sp. 1 & Pa. aiereba & Negro River, Barcelos, AM - BR & $\bullet$ & $\bullet$ & $\bullet$ \\
\hline A125 & RN11-034.02 & 7446 & Acanthobothrium amazonensis & Po. schroederi & Negro River, Barcelos, AM - BR & & $\bullet$ & $\bullet$ \\
\hline A126 & RN11-034.03 & 7447 & Acanthobothrium sp. 1 & Po. schroederi & Negro River, Barcelos, AM - BR & $\bullet$ & $\bullet$ & $\bullet$ \\
\hline A127 & RN11-034.04 & 7448 & Acanthobothrium sp. 1 & Po. schroederi & Negro River, Barcelos, AM - BR & & - & \\
\hline A129 & RN11-057.05 & 7450 & Acanthobothrium quinonesi & Po. motoro & Negro River, Barcelos, AM - BR & & $\bullet$ & $\bullet$ \\
\hline A130 & RN11-057.09 & 7451 & Acanthobothrium cf. quinonesi & Po. motoro & Negro River, Barcelos, AM - BR & $\bullet$ & $\bullet$ & $\bullet$ \\
\hline A131 & RN11-039.01 & 7452 & Acanthobothrium sp. 1 & Pa. aiereba & Negro River, Barcelos, AM - BR & - & - & $\bullet$ \\
\hline
\end{tabular}


Table A.2 - Continued from previous page

\begin{tabular}{|c|c|c|c|c|c|c|c|c|}
\hline $\begin{array}{l}\text { Molecular } \\
\text { code }\end{array}$ & Field code $\dagger$ & MZUSP & Species & Host & $\begin{array}{l}\text { Marine water body or } \\
\text { freshwater river (system) }\end{array}$ & $16 S$ & $\begin{array}{l}\text { Genes } \\
28 S\end{array}$ & ITS1 \\
\hline A132 & RN11-039.05 & 7453 & Acanthobothrium sp. 1 & Pa. aiereba & Negro River, Barcelos, AM - BR & $\bullet$ & - & - \\
\hline A133 & RN11-039.08 & 7454 & Acanthobothrium sp. 1 & Pa. aiereba & Negro River, Barcelos, AM - BR & $\bullet$ & $\bullet$ & $\bullet$ \\
\hline A134 & RN11-039.09 & 7455 & Acanthobothrium sp. & Pa. aiereba & Negro River, Barcelos, AM - BR & • & • & - \\
\hline A135 & RN11-039.11 & 7456 & Acanthobothrium sp. 1 & Pa. aiereba & Negro River, Barcelos, AM - BR & $\bullet$ & - & \\
\hline A136 & RN11-042.01 & 7457 & Acanthobothrium quinonesi & Po. schroederi & Negro River, Barcelos, AM - BR & $\bullet$ & $\bullet$ & $\bullet$ \\
\hline A138 & RN11-042.05 & 7459 & Acanthobothrium cf. sp. 2 & Po. schroederi & Negro River, Barcelos, AM - BR & & - & $\bullet$ \\
\hline A139 & RN11-042.06 & 7460 & Acanthobothrium sp. 1 & Po. schroederi & Negro River, Barcelos, AM - BR & & $\bullet$ & $\bullet$ \\
\hline A140 & RN11-037.01 & 7461 & Acanthobothrium sp. 1 & Pa. aiereba & Negro River, Barcelos, AM - BR & $\bullet$ & $\bullet$ & $\bullet$ \\
\hline A141 & RN11-037.04 & 7462 & Acanthobothrium sp. 1 & Pa. aiereba & Negro River, Barcelos, AM - BR & $\bullet$ & - & - \\
\hline A142 & RN11-037.08 & 7463 & Acanthobothrium sp. 1 & Pa. aiereba & Negro River, Barcelos, AM - BR & & $\bullet$ & $\bullet$ \\
\hline A144 & RN11-023.01 & 7465 & Acanthobothrium cf. sp. 2 & Po. schroederi & Negro River, Barcelos, AM - BR & $\bullet$ & $\bullet$ & - \\
\hline A146 & RN11-053.04 & 7467 & Acanthobothrium cf. quinonesi & Po. motoro & Negro River, Barcelos, AM - BR & $\bullet$ & $\bullet$ & $\bullet$ \\
\hline A147 & RN11-054.01 & 7468 & Acanthobothrium quinonesi & Po. motoro & Negro River, Barcelos, AM - BR & & $\bullet$ & $\bullet$ \\
\hline A148 & RN11-054.03 & 7469 & Acanthobothrium cf. amazonensis & Po. motoro & Negro River, Barcelos, AM - BR & & $\bullet$ & $\bullet$ \\
\hline A149 & RN11-054.05 & 7470 & Acanthobothrium cf. quinonesi & Po. motoro & Negro River, Barcelos, AM - BR & $\bullet$ & $\bullet$ & $\bullet$ \\
\hline A150 & RN11-050.01 & 7471 & Acanthobothrium quinonesi & Po. motoro & Negro River, Barcelos, AM - BR & $\bullet$ & $\bullet$ & $\bullet$ \\
\hline A151 & RN11-050.02 & 7472 & Acanthobothrium cf. quinonesi & Po. motoro & Negro River, Barcelos, AM - BR & & $\bullet$ & $\bullet$ \\
\hline A152 & RN11-044.01 & 7473 & Acanthobothrium quinonesi & Po. motoro & Negro River, Barcelos, AM - BR & $\bullet$ & $\bullet$ & $\bullet$ \\
\hline A153 & RN11-044.02 & 7474 & Acanthobothrium cf. quinonesi & Po. motoro & Negro River, Barcelos, AM - BR & & $\bullet$ & $\bullet$ \\
\hline A154 & RN11-056.01 & 7475 & Acanthobothrium amazonansis & Po. motoro & Negro River, Barcelos, AM - BR & & $\bullet$ & $\bullet$ \\
\hline A156 & RN11-056.05 & 7477 & Acanthobothrium cf. amazonensis & Po. motoro & Negro River, Barcelos, AM - BR & $\bullet$ & $\bullet$ & - \\
\hline A158 & RN11-029.01 & 7479 & Acanthobothrium cf. quinonesi & Po. orbignyi & Negro River, Barcelos, AM - BR & $\bullet$ & - & - \\
\hline
\end{tabular}


Table A.2 - Continued from previous page

\begin{tabular}{|c|c|c|c|c|c|c|}
\hline $\begin{array}{l}\text { Molecular } \\
\text { code }\end{array}$ & Field code $\dagger$ & MZUSP & Species & Host & $\begin{array}{l}\text { Marine water body or } \\
\text { freshwater river (system) }\end{array}$ & $\begin{array}{c}\text { Genes } \\
16 S \quad 28 S \text { ITS1 }\end{array}$ \\
\hline A160 & RN11-063.02 & 7480 & Acanthobothrium cf. amazonensis & Po. orbignyi & Negro River, Barcelos, AM - BR & - \\
\hline
\end{tabular}

$\dagger$ Field codes correspond to locations in Figure 1 (see the online Host-Parasite collection at www.ib.usp.br/hpc/hpc_index.html). 


\section{A.5 Protocolo otimizado para extração de DNA genômico com DNAdvance TM}

Nós testamos diferentes métodos para isolar DNA genômico de uma variedade de espécies de cestodas Dentre todos os métodos averiguados, o melhor rendimento foi obtido para o kit de isolamento de DNA Agencourt ${ }^{\circledR}$ DNAdvance ${ }^{\mathrm{TM}}$, que forneceu extrações mais limpas e com maiores concentrações de DNA.

Este protocolo foi otimizado para tubos eppendorf de $200 \mu \mathrm{L}$ e pequenas amostras de tecidos de cestodas $\left(<3 \mathrm{~mm}^{3}\right)$. É altamente recomendado que o tecido seja cortado em pedaços pequenos diretamente dentro dos eppendorfs de $200 \mu \mathrm{L}$. O excesso de etanol deve então ser removido com a ajuda de uma micropipeta ou por outros meios. Antes de dar início ao protocolo, deixe as amostras secarem a temperatura ambiente ou a $37^{\circ} \mathrm{C}$ por aproximadamente 30 minutos. Este protocolo empregará a placa magnética Agencourt ${ }^{\circledR}$ SPRIPlate Super Magnet Plate (96well format, produto no. A32782, a mesma placa empregada para a purificação com o kit Agencourt $^{\circledR}$ AMPure $^{\mathrm{TM}} \mathrm{XP}$ )

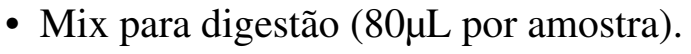

- Prepare o mix conforme a tabela abaixo. Feito isso, misture gentilmente no vórtex e dê um spin para que o material que estiver na tampa vá para o fundo do eppendorf.

\begin{tabular}{|l|c|}
\hline Lysis Buffer & $73 \mu \mathrm{l}$ \\
\hline 1M DTT & $5 \mu \mathrm{l}$ \\
\hline Proteinase K $(20 \mathrm{mg} / \mathrm{mL})$ & $4 \mu \mathrm{l}$ \\
\hline Volume Final & $80 \mu \mathrm{l}$ \\
\hline
\end{tabular}

- É aconselhável preparar o mix de digestão no gelo. O mix deve ser preparado apenas em quantidade suficiente e ser usado imediatamente após o preparo.

- Adicione $80 \mu \mathrm{l}$ do mix de digestão em cada tudo. Deposite as amostras no vórtex por alguns segundos, em seguida centrifugue gentilmente.

- Incubar a $55^{\circ} \mathrm{C}$

- Mexa as amostras s cada 15 minutos até a digestão total do tecido (o que geralmente demora menos de uma hora mas depende da quantidade de tecido).

- Centrifugue a 15.7 RCF por 10s.

- Neste momento as amostras poderão ser armazenadas a $-70^{\circ} \mathrm{C}$ caso os passos subsequentes não forem ser realizados imediatamente. 
- Adicione 50 $4 \mathrm{l}$ da solução tamponante Bind1 e pipete até ficar homogêneo.

- Misture o conteúdo do frasco de Bind2 até que todas as partículas estejam suspensas e a mistura esteja homogênea.

- Adicione $80 \mu \mathrm{l}$ de Bind2 em cada amostra. Pipete até a mistura ficar homogênea.

- Incube as amostra em temperatura ambiente por 3 minutos.

- Posicione as amostras na placa magnética e aguarde 10 minutos.

- Aspire e descarte o sobrenadante enquanto as amostras estão posicionadas sobre a placa magnética.

- Ao aspirar, posicione a ponta da pipeta no centro do tubo e cuide para que o anel de partículas magnéticas não se desfaça.

- Retire as amostras da placa. Adicione $150 \mu \mathrm{L}$ de etanol $70 \%$ e pipete até que as partículas magnéticas estejam completamente suspensos.

- Sugere-se que novas soluções de etanol 70\% sejam preparadas a cada vez que for repetir este protocolo.

- Reposicione as amostras na placa magnética por 5 minutos.

- Repita os três passos anteriores até ter completado um total de três lavagens com etanol $70 \%$.

- Remova o máximo de etanol possível antes de adicionar o Elution Buffer.

- Sugere-se secar a temperatura ambiente ou a $37^{\circ} \mathrm{C}$ por não mais que 15 minutes.

- Retire as amostras da placa magnética. Adicione 100 $\mu \mathrm{L}$ de Elution Buffer e misture com a pipeta até que todas as partículas estejam em suspensão.

- Reposicione as amostras sobre a placa magnética por 6 minutos.

- Transfira $80 \mu \mathrm{L}$ do sobrenadante para uma placa limpa ou tubo de armazenamento.

- Aspire lentamente para não perturbar o anel de partículas magnéticas. Transferir todos os $100 \mu \mathrm{L}$ de produto final não é recomendável pois pode trazer alguns partículas magnéticas. Se partículas estiverem sendo aspirados durante a transferência, dispense a amostra de volta ao seu tubo original e incube por mais 6 minutos na placa magnética antes de tentar a transferência novamente. 
- Se as amostras forem ser armazenadas por um longo período antes do uso, mantenha-as a $-70^{\circ} \mathrm{C}$. Armazene as amostras entre 4 e $-20^{\circ} \mathrm{C}$ enquanto as estiver usando. 


\section{A.6 Protocolo otimizado para purificação de DNA genômico com AMPure ${ }^{\mathrm{TM}}$ kit}

- Adicione um volume de Agencourt $^{\circledR}$ AMPure $^{\mathrm{TM}}$ XP iqual a 1,8 vezes o volume de amostra a ser purificada.

- O volume final não deve ser menor do que $25 \mu \mathrm{L}$ ou a placa magnética não será capaz de separar as partículas magnéticas do retante da solução.

- Posicione as amostras no vórtex brevemente. Em seguida, centrifugue-as brevemente para que todo o material da tampa vá para o fundo do tubo.

- Incube em temperatura ambiente por 5 minutos.

- Posicione as amostras na placa magnética (Agencourt ${ }^{\circledR}$ SPRIPlate Super Magnet Plate, produto no. A32782) por 3 minutes.

- Ainda com as amostras sobre a placa magnética, aspire e descarte o sobrenadante.

- Enquanto estiver aspirando, posicione a pipeta no centro do tubo para evitar que o anel de partículas magnéticas seja desfeito.

- Adicione gentilmente $150 \mu \mathrm{l}$ de etanol $70 \%$ para não desfazer o anel.

- Recomenda-se fazer novas soluções de etanol 70\% a cada vez que se for repetir este protocolo.

- Repita os dois passos anteriores até se completarem duas lavagens com etanol $70 \%$.

- Remova o máximo de etanol possível com a ajuda da pipeta.

- Após ter removido o etanol com a pipeta, deixe as amostras secarem a $37^{\circ} \mathrm{C}$ por 15 minutos.

- Adicione $15 \mu$ de água Milli-Q misture até que todas as partículas estejam em suspensão.

- Deixe as amostras descansarem a temperatura ambiente por 5 minutos e centrifugue a 15,7 RCF por 3 minutos.

- Transfira o sobrenadante para um tubo novo e armazene a $-20^{\circ} \mathrm{C}$. Caso as amostras devam ser armazenadas por um longo período antes do uso, mantenha-as a $-70^{\circ} \mathrm{C}$. 


\section{A.7 Sequence data acquired from GenBank}

Table A.3: GenBank data for Proteocephalidea and Acanthobothrium.

\begin{tabular}{|c|c|c|c|c|}
\hline \multirow[t]{2}{*}{ Species } & \multirow[t]{2}{*}{ Host } & \multirow{2}{*}{$\begin{array}{l}\text { Marine water body or } \\
\text { freshwater river system }\end{array}$} & \multicolumn{2}{|c|}{ Gen Bank } \\
\hline & & & $16 S$ & $28 S$ \\
\hline \multicolumn{5}{|l|}{ Acanthobothrium spp. } \\
\hline A. brevissime & Dasyatis say & Gulf of Mexico, Florida, U.S.A. & EU660532 & - \\
\hline A. parviuncinatum & Urobatis maculatus & Baja California, Mexico & - & EF095264 \\
\hline Acanthobothrium sp. 1 & Dasyatis logus & Baja California, Mexico & - & AF286953 \\
\hline \multicolumn{5}{|l|}{ Proteocephalidea specimens } \\
\hline Acanthotaenia sp. & Varanus exanthematicus & Ghana & AJ389480 & AJ388593 \\
\hline Gangesia parasiluri & Silurus asotus & Nagano prefecture, Lake Suwa, Japan & AJ389477 & AJ388590 \\
\hline Silurotaenia siluri & Silurus glanis & Orlik water reserve, Czech Republic & AJ389479 & AJ388592 \\
\hline Proteocephalus pirarara & Phractocephalus hemioliopterus & Amazonas, Itacoatiara, Brazil & - & AJ388616 \\
\hline Rudolphiella piracatinga & Calophysus macropterus & Amazonas, Itacoatiara, Brazil & - & AJ388627 \\
\hline Ophiotaenia jarara & Bothrops jararaca & Domingos Martins, Espirito Santo, Brazil & - & AJ388607 \\
\hline Proteocephalus percae & Perca fluviatilis & Neuchatel Lake, Switzerland & - & AJ388594 \\
\hline Proteocephalus tetrastomus & Hypomesus nipponensis & Nagano prefecture, Lake Suwa, Japan & - & AJ388635 \\
\hline Nomimoscolex lenha & Sorubimichthys planiceps & Amazonas, Itacoatiara, Brazil & - & AJ388611 \\
\hline Zygobothrium megacephalum & Phractocephalus hemioliopterus & Amazonas, Itacoatiara, Brazil & - & AJ388621 \\
\hline
\end{tabular}




\section{A.8 Sequence data acquired from Fyler (2009)}

Table A.4: Specimens of Acanthobothrium sequenced by Fyler (2009) with molecular codes, host codes, and localities.

\begin{tabular}{|c|c|c|c|c|c|}
\hline $\begin{array}{l}\text { Molecular } \\
\text { code }\end{array}$ & Species & Host & Host code $\dagger$ & $\begin{array}{l}\text { Marine water body or } \\
\text { freshwater river (system) }\end{array}$ & Coordinates \\
\hline CF01 & Acanthobothrium sp. & Himantura leoparda & NT-37 & $\begin{array}{l}\text { Northen Territory, east of Wessel Islands, } \\
\text { Arafura Sea, Pacific Ocean, Australia }\end{array}$ & $-11.296,136.986$ \\
\hline CF02 & Acanthobothrium sp. & Narcine entemedor & $\mathrm{BJ}-107$ & $\begin{array}{l}\text { Bahia de Los Angeles, Baja California, } \\
\text { Pacific Ocean, Mexico }\end{array}$ & $28.986,-113.537$ \\
\hline $\mathrm{CF} 03$ & Acanthobothrium sp. & Rhinobatos rhinobatos & SE-205 & Atlantic Ocean, Senegal & $14.678,-17.454$ \\
\hline CF04 & Acanthobothrium sp. & Raja velezi & $\mathrm{BJ}-243$ & $\begin{array}{l}\text { Santa Rosalia, Baja California Sur, Pacific } \\
\text { Ocean, Mexico }\end{array}$ & $27.331,-112.254$ \\
\hline CF05 & A. etini & Himantura polylepis & BO-496 & $\begin{array}{l}\text { Kampung Abai, Kinebatangan River, Sabah, } \\
\text { Borneo, Kinabatangan River, Malaysia }\end{array}$ & $5.686,118.388$ \\
\hline CF06 & A. cf. woodsholei & Dasyatis sp. & SE-222 & Mbour, Atlantic Ocean, Senegal & $14.406,-16.971$ \\
\hline $\mathrm{CF} 07$ & Acanthobothrium sp. & Raja miraletus & SE-56 & Atlantic Ocean, Senegal & $14.678,-17.455$ \\
\hline CF09 & Acanthobothrium sp. & Pastinachus atrus & NT-105 & $\begin{array}{l}\text { Northen Territory, east of Wessel Islands, } \\
\text { Arafura Sea, Pacific Ocean, Australia }\end{array}$ & $-11.296,136.988$ \\
\hline $\mathrm{CF} 24$ & Acanthobothrium sp. & Brachaelurus waddi & KJG-1 & Coast of Sydney, Pacific Ocean, Australia & No data available \\
\hline $\mathrm{CF} 25$ & A. cf. angelae & Hypnos monopterygius & KJG-7 & Coast of Sydney, Pacific Ocean, Australia & No data available \\
\hline CF26 & A. cf. angelae & Hypnos monopterygius & KJG-7 & Coast of Sydney, Pacific Ocean, Australia & No data available \\
\hline $\mathrm{CF} 27$ & A. cf. angelae & Hypnos monopterygius & KJG-7 & Coast of Sydney, Pacific Ocean, Australia & No data available \\
\hline
\end{tabular}


Table A.4 - Continued from previous page

\begin{tabular}{|c|c|c|c|c|c|}
\hline $\begin{array}{l}\text { Molecular } \\
\text { code }\end{array}$ & Species & Host & Host code $\dagger$ & $\begin{array}{l}\text { Marine water body or } \\
\text { freshwater river (system) }\end{array}$ & Coordinates \\
\hline $\mathrm{CF} 31$ & A. mattaylori & Rhynchobatus laevis & NT-7 & $\begin{array}{l}\text { Nhulunbuy (Gove), Northern Territory, Gove } \\
\text { Harbor, Gulf of Carpentaria, Pacific Ocean, } \\
\text { Australia }\end{array}$ & $-12.194,136.715$ \\
\hline $\mathrm{CF} 32$ & A. jaenneae & Rhynchobatus laevis & NT-7 & $\begin{array}{l}\text { Nhulunbuy (Gove), Northern Territory, Gove } \\
\text { Harbor, Gulf of Carpentaria, Pacific Ocean, } \\
\text { Australia }\end{array}$ & $-12.194,136.715$ \\
\hline $\mathrm{CF} 33$ & A. hypermekkolpos & Rhynchobatus laevis & NT-7 & $\begin{array}{l}\text { Nhulunbuy (Gove), Northern Territory, Gove } \\
\text { Harbor, Gulf of Carpentaria, Pacific Ocean, } \\
\text { Australia }\end{array}$ & $-12.194,136.715$ \\
\hline CF34 & A. hypermekkolpos & Rhynchobatus laevis & NT-7 & $\begin{array}{l}\text { Nhulunbuy (Gove), Northern Territory, Gove } \\
\text { Harbor, Gulf of Carpentaria, Pacific Ocean, } \\
\text { Australia }\end{array}$ & $-12.194,136.716$ \\
\hline CF35 & A. herronorum & Rhynchobatus cf. laevis & NT-66 & $\begin{array}{l}\text { Northen Territory, east of Wessel Islands, } \\
\text { Arafura Sea, Pacific Ocean, Australia }\end{array}$ & $-11.296,137.016$ \\
\hline CF37 & Acanthobothrium sp. & Dipturus batis & AZ-10 & $\begin{array}{l}\text { Horta, Azores Islands, Faial Island, Atlantic } \\
\text { Ocean, Portugal }\end{array}$ & $38.517,-28.649$ \\
\hline CF40 & Acanthobothrium sp. & Rhinobatos cemiculus & SE-134 & Atlantic Ocean, Senegal & $14.678,-17.483$ \\
\hline CF41 & Acanthobothrium sp. & Rhinobatos cemiculus & SE-134 & Atlantic Ocean, Senegal & $14.678,-17.483$ \\
\hline CF45 & Acanthobothrium sp. & Pteromylaeus bovinus & SE-143 & St. Louis, Atlantic Ocean, Senegal & $16.024,-16.534$ \\
\hline CF46 & Acanthobothrium sp. & Neotrygon cf. kuhlii & BO-409 & $\begin{array}{l}\text { Sarawak, Borneo, South China Sean, Pacifc } \\
\text { Ocean, Malaysia }\end{array}$ & $2.817,110.901$ \\
\hline
\end{tabular}


Table A.4 - Continued from previous page

\begin{tabular}{|c|c|c|c|c|c|}
\hline $\begin{array}{l}\text { Molecular } \\
\text { code }\end{array}$ & Species & Host & Host code $\dagger$ & $\begin{array}{l}\text { Marine water body or } \\
\text { freshwater river (system) }\end{array}$ & Coordinates \\
\hline CF47 & A. cf. brevissime & Dasyatis say & MS05-402 & $\begin{array}{l}\text { Florida, Crooked Island Bay, Gulf of Mexico, } \\
\text { Atlantic Ocean, U.S.A. }\end{array}$ & $29.994,-85.551$ \\
\hline CF48 & A. cf. brevissime & Dasyatis say & MS05-402 & $\begin{array}{l}\text { Florida, Crooked Island Bay, Gulf of Mexico, } \\
\text { Atlantic Ocean, U.S.A. }\end{array}$ & $29.994,-85.551$ \\
\hline CF50 & Acanthobothrium sp. & Dasyatis sabina & MS05-431 & $\begin{array}{l}\text { Florida, Indian Pass, Gulf of Mexico, Atlantic } \\
\text { Ocean, U.S.A. }\end{array}$ & $29.669,-85.251$ \\
\hline CF51 & Acanthobothrium sp. & Raja eglanteria & MS05-421 & $\begin{array}{l}\text { Florida, Indian Pass, Gulf of Mexico, Atlantic } \\
\text { Ocean, U.S.A. }\end{array}$ & $29.669,-85.252$ \\
\hline CF52 & Acanthobothrium sp. & Raja eglanteria & MS05-421 & $\begin{array}{l}\text { Florida, Indian Pass, Gulf of Mexico, Atlantic } \\
\text { Ocean, U.S.A. }\end{array}$ & $29.669,-85.252$ \\
\hline CF53 & Acanthobothrium sp. & Himantura lobistoma & BO-268 & $\begin{array}{l}\text { Mukah, Sarawak, Borneo, South China Sean, } \\
\text { Pacifc Ocean, Malaysia }\end{array}$ & $2.898,112.119$ \\
\hline CF61 & Acanthobothrium sp. & Dasyatis sp. & SE-222 & Mbour, Atlantic Ocean, Senegal & $14.406,-17.003$ \\
\hline CF65 & Acanthobothrium sp. & Paragaleus pectoralis & SE-129 & Ouakam, Atlantic Ocean, Senegal & $14.715,-17.519$ \\
\hline CF68 & $\begin{array}{l}\text { Uncibilocularis } \\
\text { squireorum }\end{array}$ & Himantura cf. urarnak & CM03-3 & $\begin{array}{l}\text { Weipa, Queensland, Gulf of Carpentaria, } \\
\text { Indian Ocean, Australia }\end{array}$ & $-12.586,141.736$ \\
\hline CF69 & Acanthobothrium sp. & Brachaelurus waddi & KJG-1 & Coast of Sydney, Pacific Ocean, Australia & No data available \\
\hline CF70 & A. cf. lasti & Himantura leoparda & NT-117 & $\begin{array}{l}\text { Northen Territory, east of Wessel Islands, } \\
\text { Arafura Sea, Pacific Ocean, Australia }\end{array}$ & $-11.296,137.020$ \\
\hline CF72 & N. gen. n. sp. 1 & Pristis clavata & AU-36 & $\begin{array}{l}\text { Buffalo Creek, Timor Sea, Indian Ocean, } \\
\text { Australia }\end{array}$ & $-12.336,130.937$ \\
\hline
\end{tabular}


Table A.4 - Continued from previous page

\begin{tabular}{|c|c|c|c|c|c|}
\hline $\begin{array}{l}\text { Molecular } \\
\text { code }\end{array}$ & Species & Host & Host code $\dagger$ & $\begin{array}{l}\text { Marine water body or } \\
\text { freshwater river (system) }\end{array}$ & Coordinates \\
\hline CF73 & N. gen. n. sp. 1 & Pristis clavata & AU-36 & $\begin{array}{l}\text { Buffalo Creek, Timor Sea, Indian Ocean, } \\
\text { Australia }\end{array}$ & $-12.336,130.938$ \\
\hline CF75 & Acanthobothrium sp. & Gymnura altavela & SE-275 & $\begin{array}{l}\text { Kafountine, Casamance, Atlantic Ocean, } \\
\text { Senegal }\end{array}$ & $12.928,-16.788$ \\
\hline CF77 & Acanthobothrium sp. & Gymnura altavela & SE-305 & Joal, Atlantic Ocean, Senegal & $14.175,-16.888$ \\
\hline CF78 & Acanthobothrium sp. & Zanobatus schoenleinii & SE-199 & Atlantic Ocean, Senegal & $14.678,-17.488$ \\
\hline CF79 & Acanthobothrium sp. & Taeniura grabata & SE-224 & Mbour, Atlantic Ocean, Senegal & $14.406,-17.005$ \\
\hline CF80 & Acanthobothrium sp. & Dasyatis margaritella & SE-234 & Djifere, Atlantic Ocean, Senegal & $13.931,-16.789$ \\
\hline CF81 & N. gen. n. sp. 2 & Pristis clavata & AU-36 & $\begin{array}{l}\text { Buffalo Creek, Timor Sea, Indian Ocean, } \\
\text { Australia }\end{array}$ & $-12.336,130.939$ \\
\hline $\mathrm{CF} 82$ & N. gen. n. sp. 2 & Pristis clavata & AU-36 & $\begin{array}{l}\text { Buffalo Creek, Timor Sea, Indian Ocean, } \\
\text { Australia }\end{array}$ & $-12.336,130.939$ \\
\hline CF85 & A. cf. terezae & Potomotrygon cf. motoro & PU-4 & $\begin{array}{l}\text { Boca Manu, Madre de Dios, Madre de Dios } \\
\text { River, Peru }\end{array}$ & $-12.267,-70.956$ \\
\hline CF87 & A. rodmani & Himantura sp. & NT-96 & $\begin{array}{l}\text { Northen Territory, east of Wessel Islands, } \\
\text { Arafura Sea, Pacific Ocean, Australia }\end{array}$ & $-11.296,137.023$ \\
\hline CF89 & A. romanowi & Himantura sp. & NT-96 & $\begin{array}{l}\text { Northen Territory, east of Wessel Islands, } \\
\text { Arafura Sea, Pacific Ocean, Australia }\end{array}$ & $-11.296,137.024$ \\
\hline CF93 & A. oceanharvestae & Himantura sp. & NT-96 & $\begin{array}{l}\text { Northen Territory, east of Wessel Islands, } \\
\text { Arafura Sea, Pacific Ocean, Australia }\end{array}$ & $-11.296,137.024$ \\
\hline CF96 & $\begin{array}{l}\text { Potamotrygonocestus cf. } \\
\text { fitzgeraldae }\end{array}$ & Potomotrygon castexi & PU-23 & Madre de Dios, Madre de Dios River, Peru & $-12.283,-70.924$ \\
\hline
\end{tabular}


Table A.4 - Continued from previous page

\begin{tabular}{|c|c|c|c|c|c|}
\hline $\begin{array}{l}\text { Molecular } \\
\text { code }\end{array}$ & Species & Host & Host code $\dagger$ & $\begin{array}{l}\text { Marine water body or } \\
\text { freshwater river (system) }\end{array}$ & Coordinates \\
\hline CF100 & A. margieae & Orectolobus japonicus & TW-19 & $\begin{array}{l}\text { Magong, Penghu, Taiwan Strait, Pacific } \\
\text { Ocean, Taiwan }\end{array}$ & $23.564,119.608$ \\
\hline CF103 & Acanthobothrium sp. & Himantura undulata & KA-43 & $\begin{array}{l}\text { Muara Pasir, East Kalimantan, Borneo, } \\
\text { Makassar Strait, Pacific Ocean, Indonesia }\end{array}$ & $-1.766,116.425$ \\
\hline CF105 & A. santarosaliense & Heterodontus mexicanus & BJ-300 & $\begin{array}{l}\text { Santa Rosalia, Baja California Sur, Pacific } \\
\text { Ocean, Mexico }\end{array}$ & $27.331,-112.292$ \\
\hline CF108 & A. cf. microcephalum & Myliobatis californica & BJ-626 & $\begin{array}{l}\text { Bahia de Los Angeles, Baja California, } \\
\text { Pacific Ocean, Mexico }\end{array}$ & $28.986,-113.575$ \\
\hline CF111 & A. popi & Himantura sp. & NT-96 & $\begin{array}{l}\text { Northen Territory, east of Wessel Islands, } \\
\text { Arafura Sea, Pacific Ocean, Australia }\end{array}$ & $-11.296,137.026$ \\
\hline CF116 & A. romanowi & Himantura sp. & NT-96 & $\begin{array}{l}\text { Northen Territory, east of Wessel Islands, } \\
\text { Arafura Sea, Pacific Ocean, Australia }\end{array}$ & $-11.296,137.026$ \\
\hline CF120 & A. popi & Himantura sp. & NT-96 & $\begin{array}{l}\text { Northen Territory, east of Wessel Islands, } \\
\text { Arafura Sea, Pacific Ocean, Australia }\end{array}$ & $-11.296,137.026$ \\
\hline CF121 & A. zimmeri & Himantura sp. & NT-96 & $\begin{array}{l}\text { Northen Territory, east of Wessel Islands, } \\
\text { Arafura Sea, Pacific Ocean, Australia }\end{array}$ & $-11.296,137.026$ \\
\hline $\mathrm{CF} 122$ & A. zimmeri & Himantura sp. & NT-96 & $\begin{array}{l}\text { Northen Territory, east of Wessel Islands, } \\
\text { Arafura Sea, Pacific Ocean, Australia }\end{array}$ & $-11.296,137.027$ \\
\hline $\mathrm{CF} 123$ & A. romanowi & Himantura sp. & NT-96 & $\begin{array}{l}\text { Northen Territory, east of Wessel Islands, } \\
\text { Arafura Sea, Pacific Ocean, Australia }\end{array}$ & $-11.296,137.027$ \\
\hline CF124 & A. rodmani & Himantura sp. & NT-96 & $\begin{array}{l}\text { Northen Territory, east of Wessel Islands, } \\
\text { Arafura Sea, Pacific Ocean, Australia }\end{array}$ & $-11.296,137.027$ \\
\hline
\end{tabular}


Table A.4 - Continued from previous page

\begin{tabular}{|c|c|c|c|c|c|}
\hline $\begin{array}{l}\text { Molecular } \\
\text { code }\end{array}$ & Species & Host & Host code $\dagger$ & $\begin{array}{l}\text { Marine water body or } \\
\text { freshwater river (system) }\end{array}$ & Coordinates \\
\hline CF126 & A. oceanharvestae & Himantura sp. & NT-96 & $\begin{array}{l}\text { Northen Territory, east of Wessel Islands, } \\
\text { Arafura Sea, Pacific Ocean, Australia }\end{array}$ & $-11.296,137.028$ \\
\hline CF128 & A. margieae & Orectolobus japonicus & TW-19 & $\begin{array}{l}\text { Magong, Penghu, Taiwan Strait, Pacific } \\
\text { Ocean, Taiwan }\end{array}$ & $23.564,119.611$ \\
\hline CF130 & Acanthobothrium sp. & Himantura cf. gerrardi & KA-211 & $\begin{array}{l}\text { Sidu, West Kalimantan, Borneo, Java Sea, } \\
\text { Pacific Ocean, Indonesia }\end{array}$ & $-1.363,110.111$ \\
\hline CF134 & Acanthobothrium sp. & Himantura lobistoma & BO-480 & $\begin{array}{l}\text { Mukah, Sarawak, Borneo, South China Sean, } \\
\text { Pacifc Ocean, Malaysia }\end{array}$ & $2.898,112.128$ \\
\hline CF136 & A. etini & Himantura polylepis & BO-108 & $\begin{array}{l}\text { Kampung Abai, Kinebatangan River, Sabah, } \\
\text { Borneo, Kinabatangan River, Malaysia }\end{array}$ & $5.686,118.429$ \\
\hline CF138 & A. masnihae & Himantura polylepis & BO-108 & $\begin{array}{l}\text { Kampung Abai, Kinebatangan River, Sabah, } \\
\text { Borneo, Kinabatangan River, Malaysia }\end{array}$ & $5.686,118.429$ \\
\hline CF139 & A. saliki & Himantura polylepis & BO-108 & $\begin{array}{l}\text { Kampung Abai, Kinebatangan River, Sabah, } \\
\text { Borneo, Kinabatangan River, Malaysia }\end{array}$ & $5.686,118.429$ \\
\hline CF140 & A. zainili & Himantura polylepis & BO-108 & $\begin{array}{l}\text { Kampung Abai, Kinebatangan River, Sabah, } \\
\text { Borneo, Kinabatangan River, Malaysia }\end{array}$ & $5.686,118.429$ \\
\hline CF141 & A. etini & Himantura polylepis & BO-108 & $\begin{array}{l}\text { Kampung Abai, Kinebatangan River, Sabah, } \\
\text { Borneo, Kinabatangan River, Malaysia }\end{array}$ & $5.686,118.430$ \\
\hline CF142 & A. masnihae & Himantura polylepis & BO-108 & $\begin{array}{l}\text { Kampung Abai, Kinebatangan River, Sabah, } \\
\text { Borneo, Kinabatangan River, Malaysia }\end{array}$ & $5.686,118.430$ \\
\hline CF143 & A. masnihae & Himantura polylepis & BO-108 & $\begin{array}{l}\text { Kampung Abai, Kinebatangan River, Sabah, } \\
\text { Borneo, Kinabatangan River, Malaysia }\end{array}$ & $5.686,118.430$ \\
\hline
\end{tabular}


Table A.4 - Continued from previous page

\begin{tabular}{|c|c|c|c|c|c|}
\hline $\begin{array}{l}\text { Molecular } \\
\text { code }\end{array}$ & Species & Host & Host code $\dagger$ & $\begin{array}{l}\text { Marine water body or } \\
\text { freshwater river (system) }\end{array}$ & Coordinates \\
\hline CF144 & A. etini & Himantura polylepis & BO-108 & $\begin{array}{l}\text { Kampung Abai, Kinebatangan River, Sabah, } \\
\text { Borneo, Kinabatangan River, Malaysia }\end{array}$ & $5.686,118.431$ \\
\hline CF145 & A. saliki & Himantura polylepis & BO-108 & $\begin{array}{l}\text { Kampung Abai, Kinebatangan River, Sabah, } \\
\text { Borneo, Kinabatangan River, Malaysia }\end{array}$ & $5.686,118.431$ \\
\hline CF146 & A. saliki & Himantura polylepis & BO-108 & $\begin{array}{l}\text { Kampung Abai, Kinebatangan River, Sabah, } \\
\text { Borneo, Kinabatangan River, Malaysia }\end{array}$ & $5.686,118.431$ \\
\hline CF147 & Acanthobothrium sp. & Raja eglanteria & TM-1 & $\begin{array}{l}\text { Cape Point, North Carolina, Western Atlantic } \\
\text { Ocean, U.S.A. }\end{array}$ & $35.250,-75.565$ \\
\hline CF151 & A. ramiroi & Potamotrygon motoro & VI-1 & Colastiné River, Santa Fé, Argentina & $-31.667,-60.815$ \\
\hline CF152 & A. ramiroi & Potamotrygon motoro & VI-2 & Colastiné River, Santa Fé, Argentina & $-31.667,-60.815$ \\
\hline CF153 & Acanthobothrium sp. & Himantura cf. gerrardi & KA-57 & $\begin{array}{l}\text { Kota Baru, South Kalimantan, Borneo, } \\
\text { Makassar Strait, Pacific Ocean, Indonesia }\end{array}$ & $-3.246,116.266$ \\
\hline CF154 & Acanthobothrium sp. & Himantura fai & KA-436 & $\begin{array}{l}\text { Manggar, East Kalimantan, Borneo, } \\
\text { Makassar Strait, Pacific Ocean, Indonesia }\end{array}$ & $-1.215,117.016$ \\
\hline
\end{tabular}

$†$ For further information, please lock for the host codes at the Global Cestode Database (http://tapewormdb.uconn.edu). 


\section{A.9 Strict consensus tree}

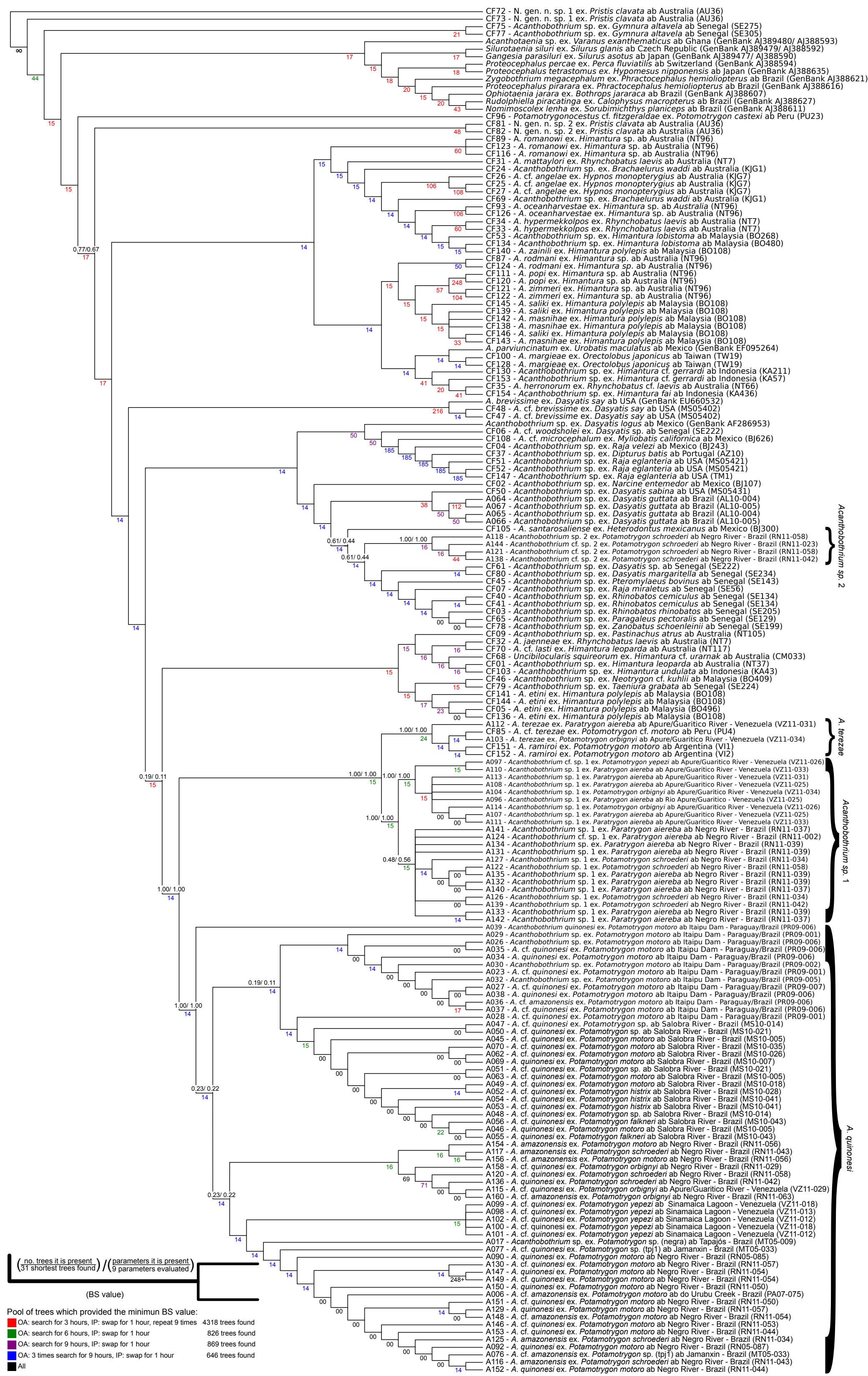

Figure A.1: Complete strict consensus tree of the trees found for parameter set 2:1:1:1, including support and stability measures. 

A.10 Cladogram with branch lengths representing the number of transformations

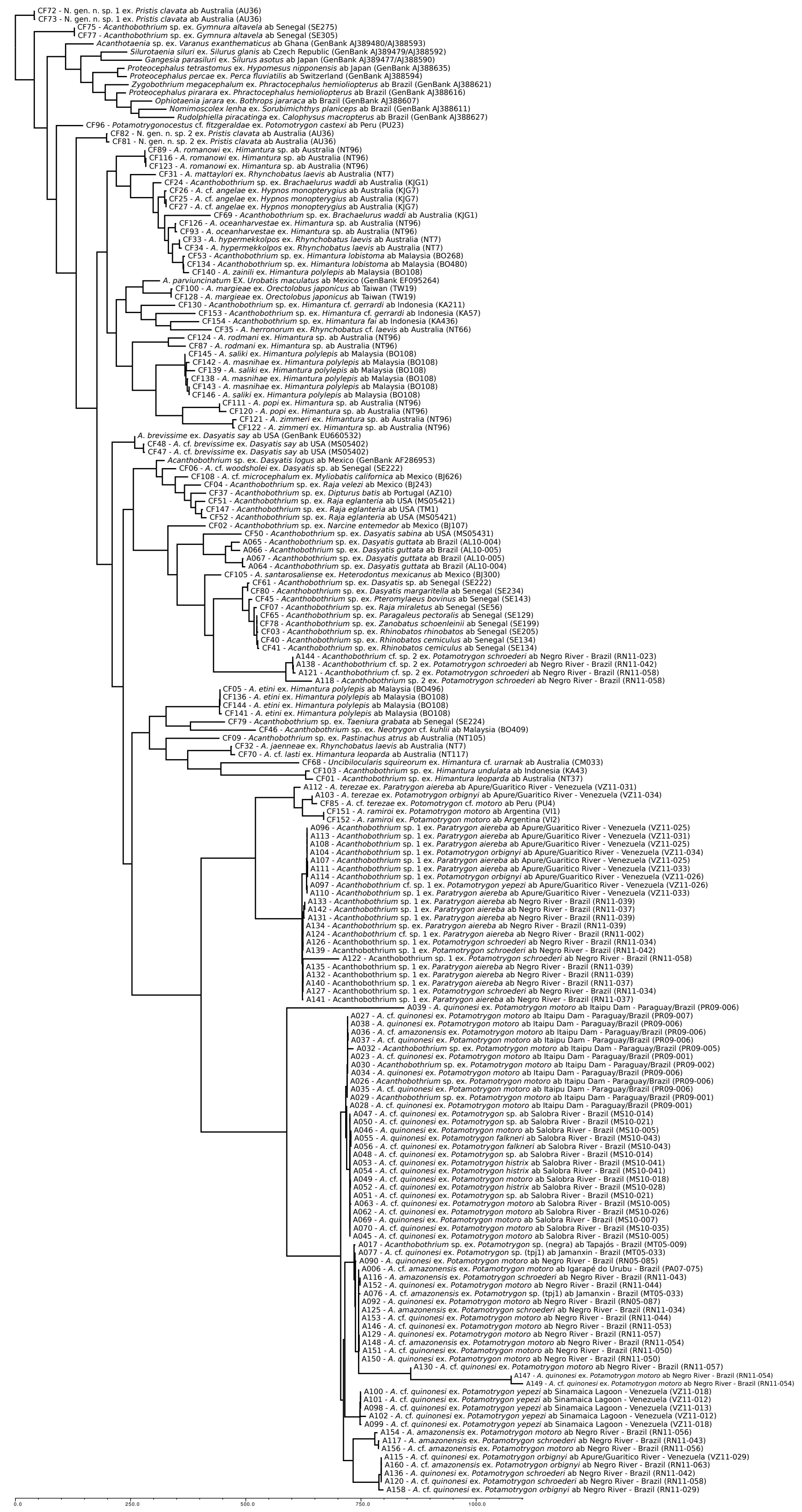

Figure A.2: Cladogram with branch lengths proportional to the number of transformations. 



\section{A.11 Descrição dos anexos eletrônicos}

Junto a esta dissertação está anexo um CD-ROM com os seguintes arquivos:

1. Um arquivo contendo o Resumo da dissertação (formato RTF)

2. Um arquivo contendo o Abstract da dissertação (formato RTF)

3. Um arquivo contendo a dissertação completa (formato PDF);

4. Um arquivo contendo os dados das sequências originais deste trabalho (formato CSV);

5. Um arquivo contendo os dados das sequências de Fyler (2009) para espécimens marinhos de Acanthobothrium (formato CSV);

6. Um arquivo contendo os dados das sequências do GenBank (formto CSV);

7. Um arquivo contendo as topologias obtidas para o parâmetro 2:1:1:1 (formato TRE); 